\title{
3. SITE 464: NORTHERN HESS RISE ${ }^{1}$
}

\author{
Shipboard Scientific Party²
}

\section{HOLE 464}

Date occupied: 17 August 1978

Date departed: 21 August 1978

Time on hole: 121 hours

Position (latitude; longitude): $39^{\circ} 51.64^{\prime} \mathrm{N} ; 173^{\circ} 53.33^{\prime} \mathrm{E}$

Water depth (corrected $\mathrm{m}$, echo sounding): 4637

Bottom felt (m, drill pipe): 4670

Penetration (m): 308.5

Number of cores: 34

Total length of cored section (m): 308.5

Total core recovered $(\mathrm{m}): 75.66$

Core recovery $(\%): 24.5$

Oldest sediment cored:

Depth sub-bottom (m): 307.6

Nature: Chert and chalk

Age: Early Albian/late Aptian

Measured velocity $(\mathrm{km} / \mathrm{s}): 5.1$ (chert)

Basement:

Depth sub-bottom (m): 307.6

Nature: Basalt

Length of cored section $(\mathrm{m}): 0.9$

Measured velocity $(\mathrm{km} / \mathrm{s}): 4.1$

Principal results: The northern part of Hess Rise, in the central North Pacific Ocean, was drilled at Site 464 (Fig. 1). A few fragments of basalt were recovered in the lowermost of 34 cores that penetrated a lower Albian (or Aptian) to lower Pleistocene sediment sequence. The basalt is highly altered, almost all primary components being replaced by smectite minerals. Trace elements indicate that the basalt is a tholeiite. Alteration of the basalt is shown both by a low compressional-wave velocity $(4.1 \mathrm{~km} / \mathrm{s})$ and by the high water contents of analyzed specimens. The sediment column, 307.6 meters thick, is divided into three lithologic units (Fig. 2). The lower unit (Unit III) is a sequence of lower Albian (or Aptian) to Cenomanian chalk, marlstone, claystone, and chert, 218.6 meters thick. Recovery in Unit III was very low because of chert. Unit III is overlain by about 53 meters of pelagic brown clay (Unit II) that ranges in age from Late Cretaceous to middle Miocene.

\footnotetext{
1 Initial Reports of the Deep Sea Drilling Project, Volume 62.

2 Tracy L. Vallier (Co-Chief Scientist), U.S. Geological Survey, Menlo Park, California; Jörn Thiede (Co-Chief scientist), Department of Geology, University of Oslo, Blindern, Oslo 3. Norway; Charles Adelseck, Jr., Deep Sea Drilling Project, Scripps Institution of Oceanography, La Jolla, California; Anne Boersma, Lamont-Doherty Geological Observatory, Palisades, New York; Pavel Čepek, Bundesanstalt für Geowissenschaften und Rohstoffe, Hannover, Federal Republic of Germany; Walter E. Dean, U.S. Geological Survey. Denver, Colorado; Napyuki Fujt, Department of Earth Sciences, Kobe Universit, Nada, Kobe,

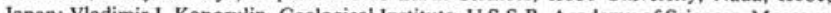
U.S.S.R. David K. Rea, Deparment of Atmuspheric and Oceric Science, University of U.S.S.R.; David K. Rea, Department of Atmospheric and Oceanic Science, University of Michigan, Ann Arbor, Michigan; Constance Sancetta, Lamont-Doherty Geological Observatory, Palisades, New York; William Sayre, Department of Oceanography, University of Southampton, Southampton, United Kingdom (present address: Department of Earth Sciences, lowa State University of Science and Technology, Ames, Jowa); André Schaaf, Institut de Géologie, Strasbourg, France; Ronald R. Schmidt, Institute of Earth Sciences, University of Utrecht, Utrecht, The Netherlands: Karl E. Seifert, Department of Earth Sciences, Jowa State University of Science and Techn: Kary, Ames, lowa; Edith Vincent, Geologieal Researh Division, Seripps Institution of Oceano Division, Scripps Institution of Oceanography, La Jolla, California, and Kenneth E. Windom, Department of Earth Sciences, Iowa State University of Science and Technology, Ames,
lowa.
}

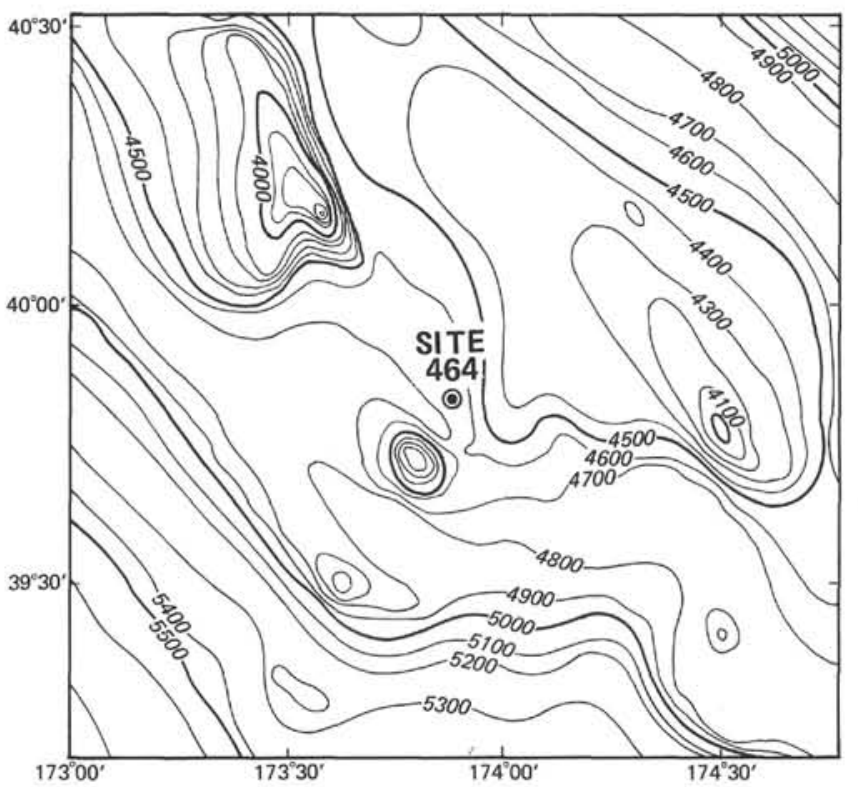

Figure 1. Site 464, northern Hess Rise. Bathymetry from Chase et al. (this volume).

Age assignments for Unit II are based on studies of ichthyoliths. Unit II is overlain by about 36 meters of clayey siliceous ooze and siliceous clay of late Miocene to early Pleistocene age.

The site has been below the local CCD through most of its history. In Cores 2 to 5 , however, moderately to strongly etched nannofossil assemblages and rare planktonic foraminifers indicate that the site was close to the CCD during the Neogene. The radiolarian and diatom assemblages of Unit I show a diverse, mixed association of equatorial and high-latitude species.

The geologic history of northern Hess Rise, as indicated by the drilling results, is consistent with an origin at a mid-ocean ridge, followed by vertical and horizontal movements of the Pacific Plate as it synchronously subsided and moved northward under different surface-water masses. High sedimentation rates in the lower Albian (or Aptian) to Cenomanian Unit III record the site's passage under the biologically fertile equatorial zone. A change from calcareous biogenic sediment to brown clay can be related both to subsidence through the local CCD in the Late Cretaceous and to movement of the site under a less-fertile water mass. The subsequent change to siliceous-fossil ooze and clay can be attributed to movement of the site under more-fertile waters that formed during the mixing of subtropical and subarctic water masses, and possibly to a closer approach to large land masses, which allowed the transport of terrigenous debris by winds.

\section{BACKGROUND AND OBJECTIVES}

Hess Rise is one of several large aseismic rises (or oceanic plateaus) in the western Pacific Ocean. It is the same order of magnitude in size as the Shatsky and Magellan Rises, the Ontong-Java and Manihiki Plateaus, and the Mid-Pacific Mountains. 


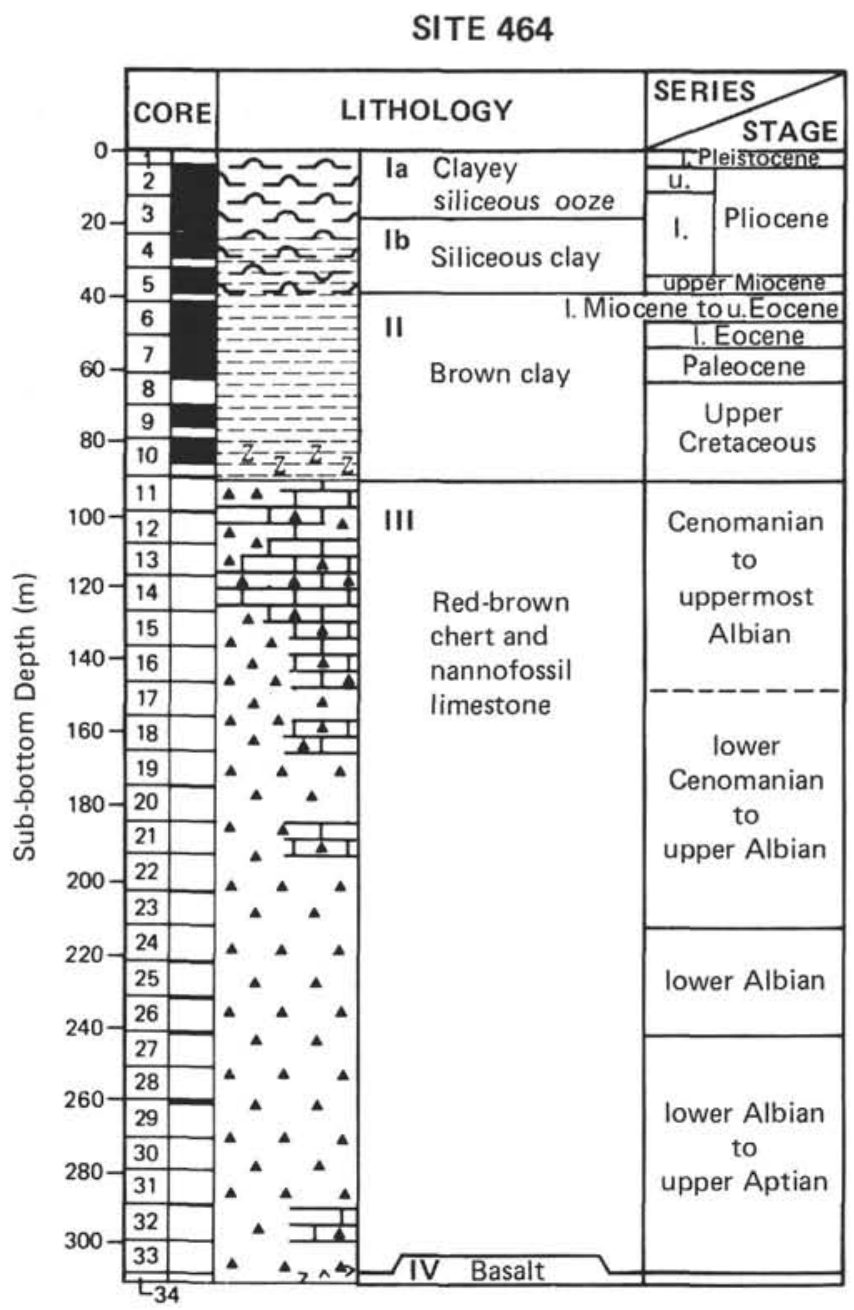

Figure 2. Stratigraphy of Site 464.

Site 464, on northern Hess Rise (Fig. 3), was chosen to answer several paleoenvironmental questions. The site is close to the transition between subtropical and subarctic surface-water masses, thereby providing an excellent opportunity to study Neogene planktonic communities within this temperate water mass. In addition, the site provides a unique opportunity for construction of a biostratigraphic transect of the transition between microfossil assemblages of Site 464 and the subtropical microfossil assemblages of Site 310 (Larson, Moberly, et al., 1975) of central Hess Rise, and Sites 465 and 466 of southern Hess Rise.

Site 310 (Larson, Moberly, et al., 1975) was drilled on central Hess Rise in 3524 meters of water. Poor weather forced abandonment of the site before igneous basement was penetrated. The lithologic column at Site 310 includes about 75 meters of middle Miocene through Quaternary, radiolarian-bearing nannofossil ooze; about 20 meters of lower Eocene to middle Miocene pelagic brown clay, zeolitic nannofossil ooze, and nannofossil ooze; 105 meters of Campanian and Maastrichtian nannofossil ooze and chert; and about 150 meters of nannofossil chalk and chert of Albian to Campanian age. At least three hiatuses interrupt the
Tertiary section. A long hiatus separates the Maastrichtian and lower Eocene.

We expected the stratigraphic column at Site 464 to be somewhat different from that at Site 310 , for three reasons. First, because the northern site crossed the Equator first, higher biogenic sedimentation rates should have occurred earlier in the Cretaceous. Second, Site 464 is more than 1000 meters deeper than Site 310, which implies that-unless later faulting was responsible for the difference in relief-the northern Hess Rise site subsided earlier below the CCD. Third, Site 464 is now closer to the subarctic surface-water mass, which should be reflected by an accumulation of Neogene and Quaternary siliceous microfossils.

High sedimentation rates of biogenic microfossils indicate when a North Pacific Ocean site crossed the equatorial high-productivity zone during northward plate movement (Winterer, 1973; Heezen et al., 1973; Berger, 1973; van Andel, 1974; among others). Therefore, by determining the equatorial crossings of the sites on Hess Rise, we planned to calculate approximate rates of northward movement.

The Conrad 10 air-gun seismic-reflection profile over proposed Site 464 (Fig. 4) shows two major sub-bottom reflectors; the first lies at about 0.15 seconds (two-way time), and the second at about 0.40 seconds. The bottom reflector may correspond to basalt basement, but apparent layering within that unit elsewhere along the profile (e.g., Conrad 10 profile at about 2130 hours, 23 June 1966) suggests that it represents either well-lithified sediment or a sill-sediment sequence. Therefore, another important objective was to recover rocks below the bottom reflector. Knowledge of the characteristics and age of this horizon is critical for developing the acoustic stratigraphy from which the geologic history of Hess Rise can be interpreted. Geochemical studies of igneous rocks can be used to interpret the geologic setting of volcanism. It is important to know whether the rocks were erupted at a mid-ocean ridge or during intraplate volcanism.

\section{OPERATIONS}

After drilling and a brief post-site survey at Site 463, we proceeded north to the first of three drill sites on Hess Rise. The northern part of Hess Rise previously had not been sampled, and we planned to reach igneous basement after penetrating a mid- to high-latitude $\mathrm{Ce}$ nozoic pelagic sequence and a Cretaceous carbonate sequence at a location chosen from a Conrad 10 seismicreflection profile,

After obtaining air-gun seismic-reflection, $3.5-\mathrm{kHz}$, $12-\mathrm{kHz}$, and magnetic profiles during the 7-day traverse, we turned (1515 L, 17 August 1978) onto the Conrad 10 track line across northern Hess Rise and steamed toward the proposed drill site (Fig. 4; Conrad 10 profile close to $0300 \mathrm{Z}$ of 24 June 1966), which is at a $4.5-\mathrm{km}$ water depth. We followed the Conrad 10 track line on a parallel course for over 5 hours at full speed, but slowed to 5.5 knots approximately 6 nautical miles south-southwest of the proposed drill site (Fig. 5). The good quality of our seismic-reflection profiles and their similarity to 


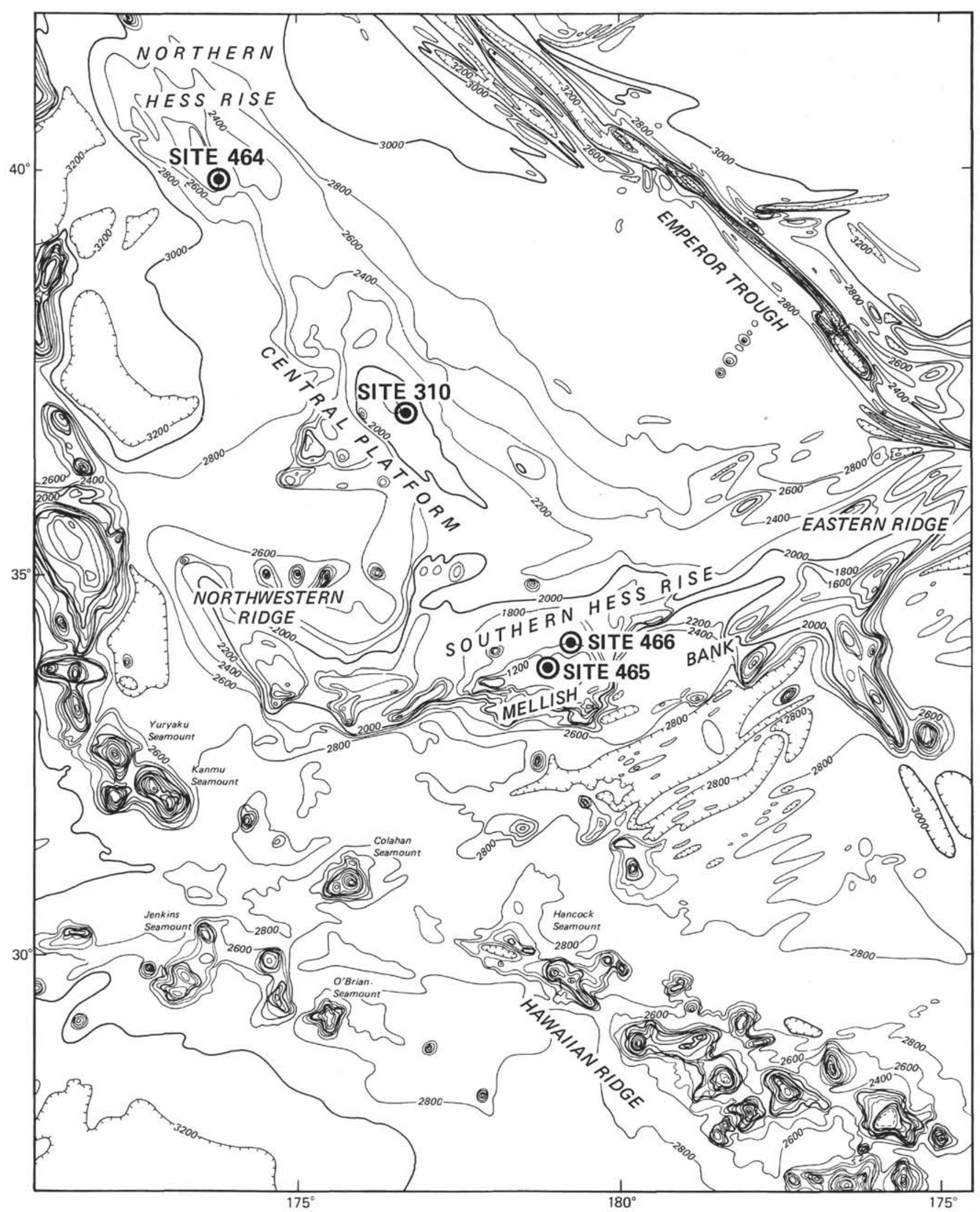

Figure 3. Location map showing sites drilled on Hess Rise. Site 310 was drilled during Leg 32. Bathymetry in fathoms (from Chase et al., 1971). 


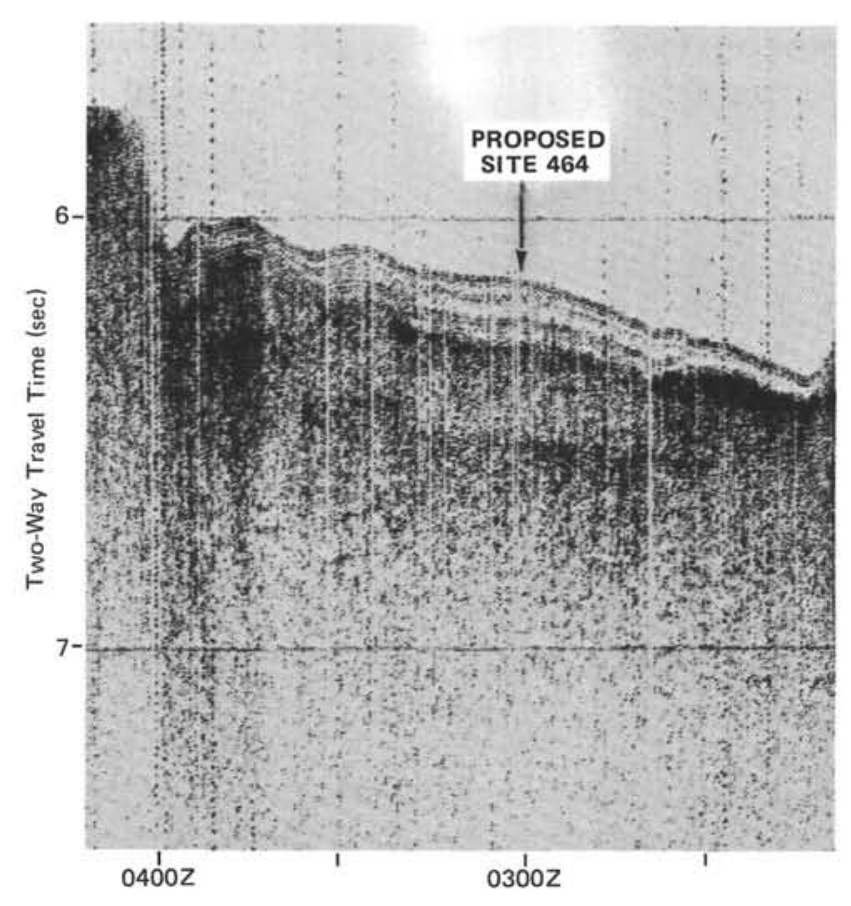

Figure 4. Proposed drill site (464) from Conrad 10 single-channel seismic-reflection record (24 June 1966). Speed was about 10 knots. Seconds are two-way time.

the Conrad 10 line allowed us to drop the beacon during our first approach to the site at $2142 \mathrm{~L}$ (0942Z), 16 August 1978 (Fig. 6). After retrieving the gear, we returned to the beacon. The ship's dynamic-positioning system was switched to automatic at $0102 \mathrm{~L}, 17$ August 1978 (1302Z, 16 August).

On-site coring operations were largely routine, although there were some problems in establishing the mud line. The first core contained only a smear of sediment. The second core was empty. Higher-than-normal pressures during the third coring attempt suggested that the bit might be plugged. After a center-bit run, pressure seemed to be normal, and some material (a few pieces of manganese nodules) was recovered. Coherent sediments finally were found at a drill-pipe depth of 4670 meters (below the rig floor). Because of the difficulty in establishing the mud line, and because the youngest recovered sediments are of early Pleistocene rather than Holocene age, we accepted the corrected PDR depth of 4637 meters for Site 464 .

Coring was continuous to a sub-bottom depth of 308.5 meters (Table 1). Core recovery was excellent in the upper part of the penetrated section, which consisted of siliceous-fossil ooze and pelagic brown clay. However, after entering a sequence of limestone, claystone, and chert, recovery dropped dramatically to about 1 to $5 \%$. No major problems were encountered during the coring until Core 34 , which required 76 minutes in order to core 1 meter. The core barrel was pulled to determine if the bit was plugged. The bit did not appear to be plugged, judging from the pump pressure observed as the new inner barrel was being dropped; however, when the barrel landed we discovered that the drill string was stuck. Water could be circulated in the hole, but the drill string could not be rotated, nor did the bumper subs operate. The pipe was worked for about 8 hours, after which it was decided that the only course of action was to shoot off the pipe. Because of adverse weather and the possibility of lightning, the shooting assembly was not put together for another 12 hours. The charge was detonated at the connection between the first and second drill collars, near the top of the bottom-hole assembly. After the drill string was recovered, the site was abandoned at $2245 \mathrm{~L}$ on 21 August 1978.

We left Site 464 in a northwesterly direction (Fig. 5) and streamed the geophysical gear in order to obtain seismic-reflection profiles perpendicular to the Conrad 10 and our own track lines. We passed the beacon within $1 \mathrm{~km}$ at about $0215 \mathrm{~L}$ on 22 August. Upon completion of the departure survey we headed south toward Site 465 .

\section{LITHOLOGIC SUMMARY}

The stratigraphic column at Site 464 was divided into four lithologic units (Table 2). Unit I is a clayey siliceous-fossil ooze and siliceous-fossil clay about 36.1 meters thick. The age range is early Pleistocene to late Miocene (Sancetta, this volume; Müller, this volume). Younger sediments probably were lost during the early coring attempts. Unit II consists of 52.9 meters of the pelagic brown clay that is characteristic of a large part of the deeper North Pacific Basin. This unit occurs between sub-bottom depths of 36.1 and 89.0 meters and represents an approximate time interval of early Miocene to Late Cretaceous (see Doyle and Riedel, this volume, for ages determined by ichthyolith studies). Underlying the brown clay are 218.6 meters of chalk, marlstone, claystone, and chert of early Cenomanian to early Albian (or Aptian) age (Ćepek, this volume). At the bottom of the hole, $16 \mathrm{~cm}$ of basalt were recovered from a 0.9 -meter cored interval before coring operations were halted.

\section{Unit IA: Clayey Radiolarian and Siliceous Ooze}

The sea floor at Site 464 probably has a veneer of manganese nodules, because several small nodules constituted the total recovery of Core 1 . Underlying the nodules, in Cores 2 and 3 , is 15.3 meters of dominantly gray, clayey siliceous-fossil ooze (Appendix A). This soft sediment is moderately to intensely disturbed by drilling. Streaks and mottles in various shades of light gray to tan are common. Clay minerals constitute about half of this sediment, and siliceous microfossils another 30 to $40 \%$. Radiolarians commonly are dominant over diatoms by roughly two to one. Silicoflagellates and sponge spicules usually constitute a few percent of the sediment in Unit IA; spicules range up to $10 \%$ of some smear slides. Calcareous nannofossils, dominantly coccoliths, average about $5 \%$ and range up to $20 \%$ of the sediment. A manganese nodule was encountered at about 7 meters depth. Bulk- and clay-mineralogy X-ray results indicate an abundance of terrigenous components in this unit (Appendix B). The recovered sedi- 


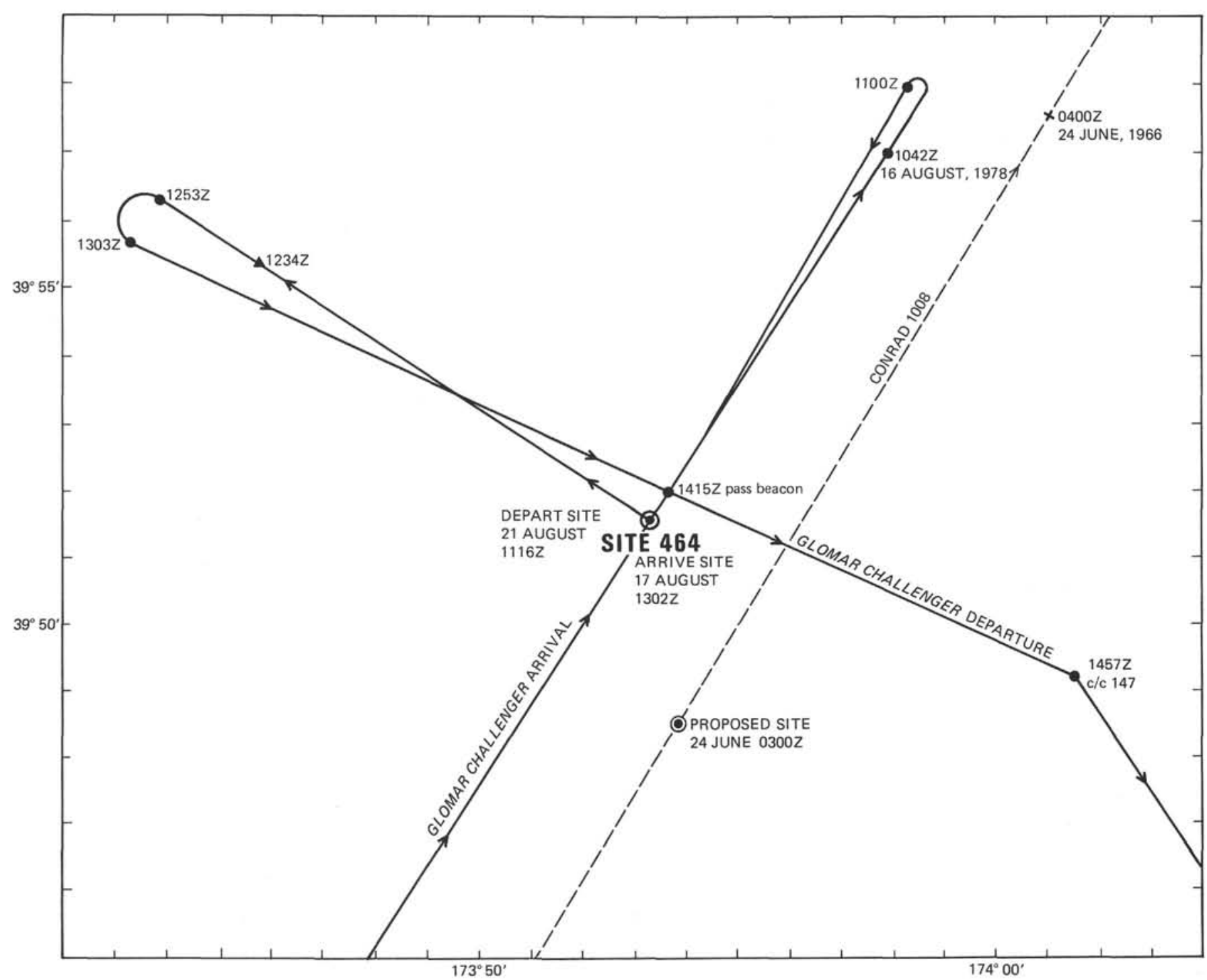

Figure 5. Track lines of Glomar Challenger during the approach to and departure from Site 464. The Conrad 10 track line (1008) is dashed. All times are Greenwich mean time $(\mathrm{Z})$.

ment in Cores 2 and 3 of Unit IA represents a time span of early to late Pliocene, about 1.3 m.y. Rare diatoms in manganese-encrusted blebs of sediment from Core 1 are early Pleistocene in age (Sancetta, this volume).

\section{Unit IB: Siliceous Clay}

Unit I B spans the interval between 18.8 and 36.1 meters sub-bottom. Clay increases to about $75 \%$ of the sediment in this unit, and nannofossils are essentially absent (Appendix A). Radiolarians and diatoms make up most of the non-clay fraction and occur in more or less equal proportions. Sponge spicules and silicoflagellates, quartz, feldspar, volcanic glass, micronodules, and fish debris all occur in trace amounts.

The siliceous clay of Unit IB is greenish-gray, with olive-gray and tan streaks and mottles in the upper part, grading down to brown and dark-brown sediment with brownish-yellow streaks and mottles below 23.0 meters to a depth of 23.5 meters. Drilling disturbance is moderate to intense. Section 1 of Core $4(22.5-24.0 \mathrm{~m})$ contains manganese nodules at 63 and $80 \mathrm{~cm}$; each is 3 or 4 $\mathrm{cm}$ in diameter. The bottom $45 \mathrm{~cm}$ of this section is a nannofossil diatom ooze containing 20 to $25 \%$ calcareous nannofossils, 35 to $40 \%$ siliceous microfossils (diatoms predominating), and only 35 to $40 \%$ clay. Unit IB becomes darker near its base and undergoes a rather abrupt facies change to the brown clay of Unit II at a sub-bottom depth of 36.1 meters. Some zeolites are present (Fig. 7), and large amounts of terrigenous material make up the non-biogenic fractions (Appendix B).

\section{Unit II: Pelagic Brown Clay}

Brown clay occurs in a layer 52.9 meters thick, 36.1 to 89.0 meters below the sea floor. The clay is dark brown to black in its upper part, becoming somewhat lighter in hue down-core, where it is brown and reddishbrown. Drilling disturbance usually is intense, and parts of the cores are soupy. Mottles and streaks occur throughout; generally, they are lighter brown than the dominant color, although some darker streaks were observed. 


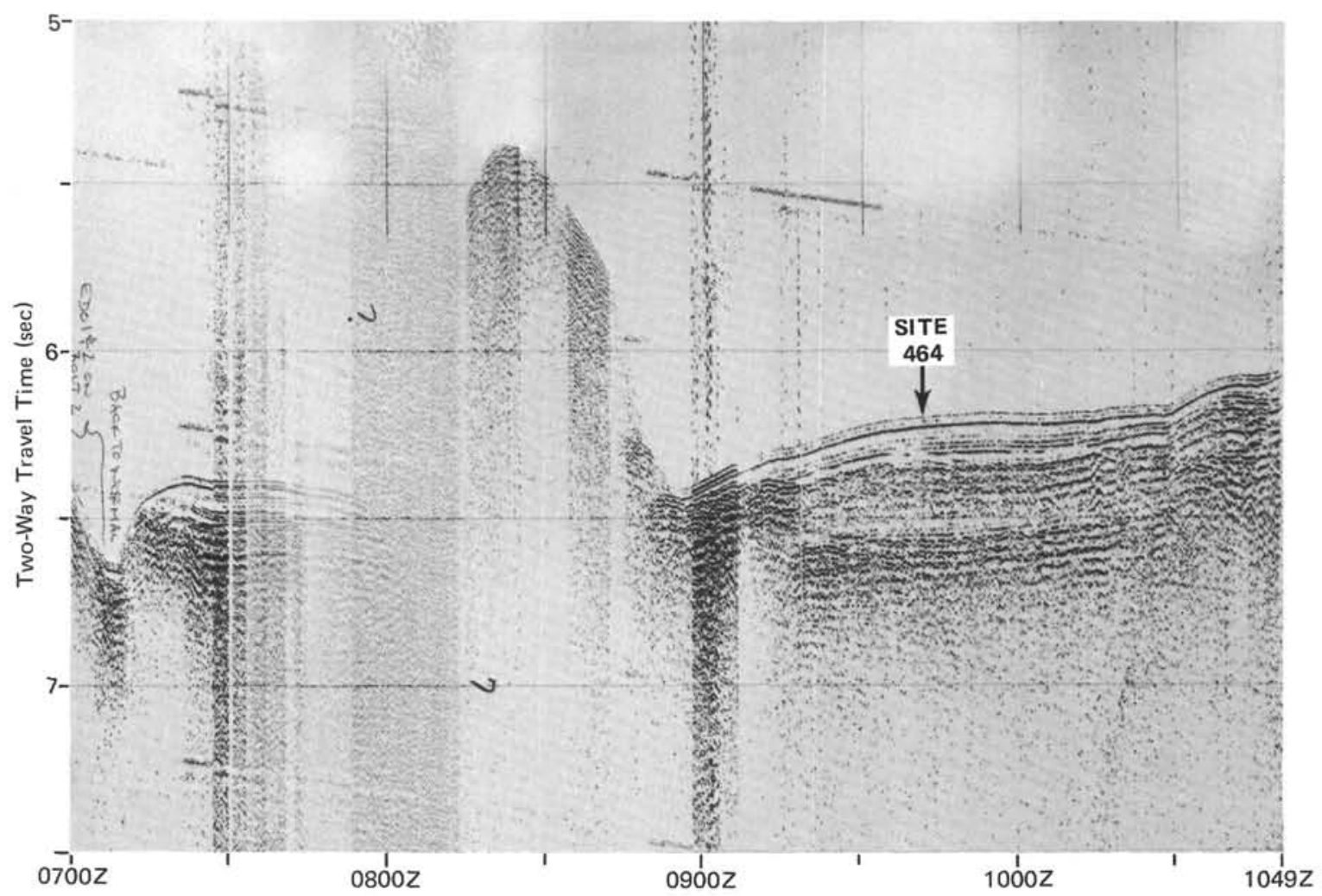

Figure 6. Single-channel seismic-reflection record made during approach to Site 464.

Table 1. Site 464 coring summary.

\begin{tabular}{|c|c|c|c|c|c|c|c|}
\hline $\begin{array}{l}\text { Core } \\
\text { No. }\end{array}$ & $\begin{array}{l}\text { Date } \\
\text { (Aug } \\
\text { 1978) }\end{array}$ & $\begin{array}{c}\text { Time } \\
\text { (L) }\end{array}$ & $\begin{array}{l}\text { Depth Fron } \\
\text { Drill Floor } \\
\quad(\mathrm{m})\end{array}$ & $\begin{array}{l}\text { Depth Below } \\
\text { Sea Floor } \\
\text { (m) } \\
\text { Top Bottom }\end{array}$ & $\begin{array}{l}\text { Length } \\
\text { Cored } \\
(\mathrm{m})\end{array}$ & $\begin{array}{l}\text { Length } \\
\text { Recovered } \\
\text { (m) }\end{array}$ & $\begin{array}{c}\text { Percent } \\
\text { Recovery }\end{array}$ \\
\hline 1 & 17 & 2045 & $4670.0-4673.5$ & $0-3.5$ & 3.5 & 0.02 & 5.7 \\
\hline 2 & 17 & 2202 & $4673.5-4683.0$ & $3.5-13.0$ & 9.5 & 9.51 & $100+$ \\
\hline 3 & 17 & 2312 & $4683.0-4692.5$ & $13.0-22.5$ & 9.5 & 8.47 & 89.2 \\
\hline 4 & 18 & 0032 & $4692.5-4702.0$ & $22.5-32.0$ & 9.5 & 6.65 & 70.0 \\
\hline 5 & 18 & 0145 & $4702.0-4711.5$ & $32.0-41.5$ & 9.5 & 7.27 & 76.5 \\
\hline 6 & 18 & 0315 & $4711.5-4721.0$ & $41.5-51.0$ & 9.5 & 9.65 & $100+$ \\
\hline 7 & 18 & 0430 & $4721.0-4730.5$ & $51.0-60.5$ & 9.5 & 8.96 & 94.3 \\
\hline 8 & 18 & 0725 & $4730.5-4740.0$ & $60.5-70.0$ & 9.5 & 1.82 & 19.2 \\
\hline 9 & 18 & 0850 & $4740.0-4749.5$ & $70.0-79.5$ & 9.5 & 5.95 & 62.6 \\
\hline 10 & 18 & 1053 & $4749.5-4759.0$ & $79.5-89.0$ & 9.5 & 5.58 & 58.7 \\
\hline 11 & 18 & 1253 & $4759.0-4768.5$ & $89.0-98.5$ & 9.5 & 0.75 & 7.9 \\
\hline 12 & 18 & 1447 & $4768.5-4778.0$ & $98.5-108.0$ & 9.5 & 0.75 & 7.9 \\
\hline 13 & 18 & 1652 & $4778.0-4787.5$ & $108.0-117.5$ & 9.5 & 0.21 & 2.2 \\
\hline 14 & 18 & 1829 & $4787.5-4797.0$ & $117.5-127.0$ & 9.5 & 0.32 & 3.4 \\
\hline 15 & 18 & 2015 & $4797.0-4806.5$ & $127.0-136.5$ & 9.5 & 0.24 & 2.5 \\
\hline 16 & 18 & 2142 & $4806.5-4816.0$ & $136.5-146.0$ & 9.5 & 0.15 & 1.6 \\
\hline 17 & 18 & 2339 & $4816.0-4825.5$ & $146.0-155.5$ & 9.5 & 0.27 & 2.8 \\
\hline 18 & 19 & 0136 & $4825.5-4835.0$ & $155.5-165.0$ & 9.5 & 0.15 & 1.6 \\
\hline 19 & 19 & 0310 & $4835,0-4844.5$ & $165.0-174.5$ & 9.5 & 0.22 & 2.3 \\
\hline 20 & 19 & 0505 & $4844.5-4854.0$ & $174.5-184.0$ & 9.5 & 0.76 & 8.0 \\
\hline 21 & 19 & 0700 & $4854.0-4863.5$ & $184.0-193.5$ & 9.5 & 0.73 & 7.7 \\
\hline 22 & 19 & 0847 & $4863.5-4873.0$ & $193.5-203.0$ & 9.5 & 0.35 & 3.7 \\
\hline 23 & 19 & 1017 & $4873.0-4882.5$ & $203.0-212.5$ & 9.5 & 0.77 & 8.1 \\
\hline 24 & 19 & 1209 & $4882.5-4892.0$ & $212.5-222.0$ & 9.5 & 0.20 & 2.1 \\
\hline 25 & 19 & 1418 & $4892.0-4901.5$ & $222.0-231.5$ & 9.5 & 0.82 & 8.6 \\
\hline 26 & 19 & 1556 & $4901.5-4911.0$ & $231.5-241.0$ & 9.5 & 0.62 & 6.5 \\
\hline 27 & 19 & 1743 & $4911.0-4920.5$ & $241.0-250.5$ & 9.5 & 0.70 & 7.3 \\
\hline 28 & 19 & 1957 & $4920.5-4930.0$ & $250.5-260.0$ & 9.5 & 0.47 & 4.9 \\
\hline 29 & 19 & 2209 & $4930.0-4939.5$ & $260.0-269.9$ & 9.5 & 1.06 & 11.2 \\
\hline 30 & 19 & 2344 & $4939.5-4949.0$ & $269.9-279.0$ & 9.5 & 0.32 & 3.4 \\
\hline 31 & 20 & 0215 & $4949.0-4958.5$ & $279.0-288.5$ & 9.5 & 0.44 & 4.6 \\
\hline 32 & 20 & 0507 & $4958.5-4968.0$ & $288.5-298.0$ & 9.5 & 0.78 & 8.2 \\
\hline 33 & 20 & 0652 & $4968.0-4977.5$ & $298.0-307.5$ & 9.5 & 0.50 & 5.0 \\
\hline \multirow[t]{2}{*}{34} & 20 & 0948 & $4977.5-4978.5$ & $307.5-308.5$ & 1.0 & 0.20 & 20.0 \\
\hline & & & & & & 75.66 & 24.5 \\
\hline
\end{tabular}

Smear-slide studies show that clay minerals make up 85 to $97 \%$ of this unit, and average about $90 \%$ (Appendix A). Other important components are micro-nodules, volcanic glass, and zeolites. Zeolites constitute $10 \%$ of the sediment at about 39 meters below the surface, and $20 \%$ in the lowest 5 meters of the unit. Quartz, feldspar, opaque minerals, and fish remains all occur as trace constituents in this unit. Light-brown concretions of zeolite (phillipsite), forming nodules up to $4 \mathrm{~cm}$ in diameter, occur in the lowest 2.5 meters of the clay unit, along with dark-reddish-brown chert. X-ray studies (Appendix B) show a large percentage of smectite in samples from Cores 6 and 7, whereas illite is abundant in Core 9.

The near absence of calcareous microfossils in the pelagic clay hindered age determinations; however, Doyle and Riedel (this volume) were able to give some tentative age assignments based on a study of ichthyoliths. According to their data, the unit ranges in age from early Miocene to Late Cretaceous.

\section{Unit III: Red-brown Chert}

The thickest sedimentary unit at Site 464 , Unit III, spans Cores 11 to $34,89.0$ to 307.6 meters below the sea floor. Chert is the dominant rock type, but recovery was very low; only three of the 23 cores contained more than 1 meter of material, and 12 had less than $50 \mathrm{~cm}$. The chert generally occurs in three colors. Chert from Cores 11 to 15 is dominantly gray. Beginning in Core 15 and 
Table 2. Lithologic units at Site 464.

\begin{tabular}{|c|c|c|c|c|c|}
\hline Unit & Lithology & Cores & $\begin{array}{l}\text { Sub-bottom } \\
\text { Depth } \\
\text { (m) }\end{array}$ & $\begin{array}{l}\text { Thickness } \\
\text { (m) }\end{array}$ & Age \\
\hline LA & $\begin{array}{l}\text { Clayey siliceous-fossil ooze } \\
\text { and clayey radiolarian ooze }\end{array}$ & $2-3^{\mathrm{a}}$ & $3.5-18.8$ & 15.3 & Late and early Pliocene \\
\hline IB & Siliceous-fossil clay & $3-5$ & $18.8-36.1$ & 17.3 & Early Pliocene and late Miocene \\
\hline II & Pelagic brown clay & $5-10$ & $36.1-89.0$ & 52.9 & Middle Miocene to Late Cretaceous \\
\hline III & $\begin{array}{l}\text { Chert, marlstone, chalk, and } \\
\text { claystone }\end{array}$ & $11-34$ & $89.0-307.6$ & 218.6 & $\begin{array}{l}\text { Earliest Cenomanian to early Albian } \\
\text { (possibly Aptian) }\end{array}$ \\
\hline IV & Basalt & 34 & $307.6-308.5$ & - & - \\
\hline
\end{tabular}

a Core 1 , from the sea floor to 3.5 meters, contained only a few manganese nodules; rare diatoms and radiolarians are of early Pleistocene age.

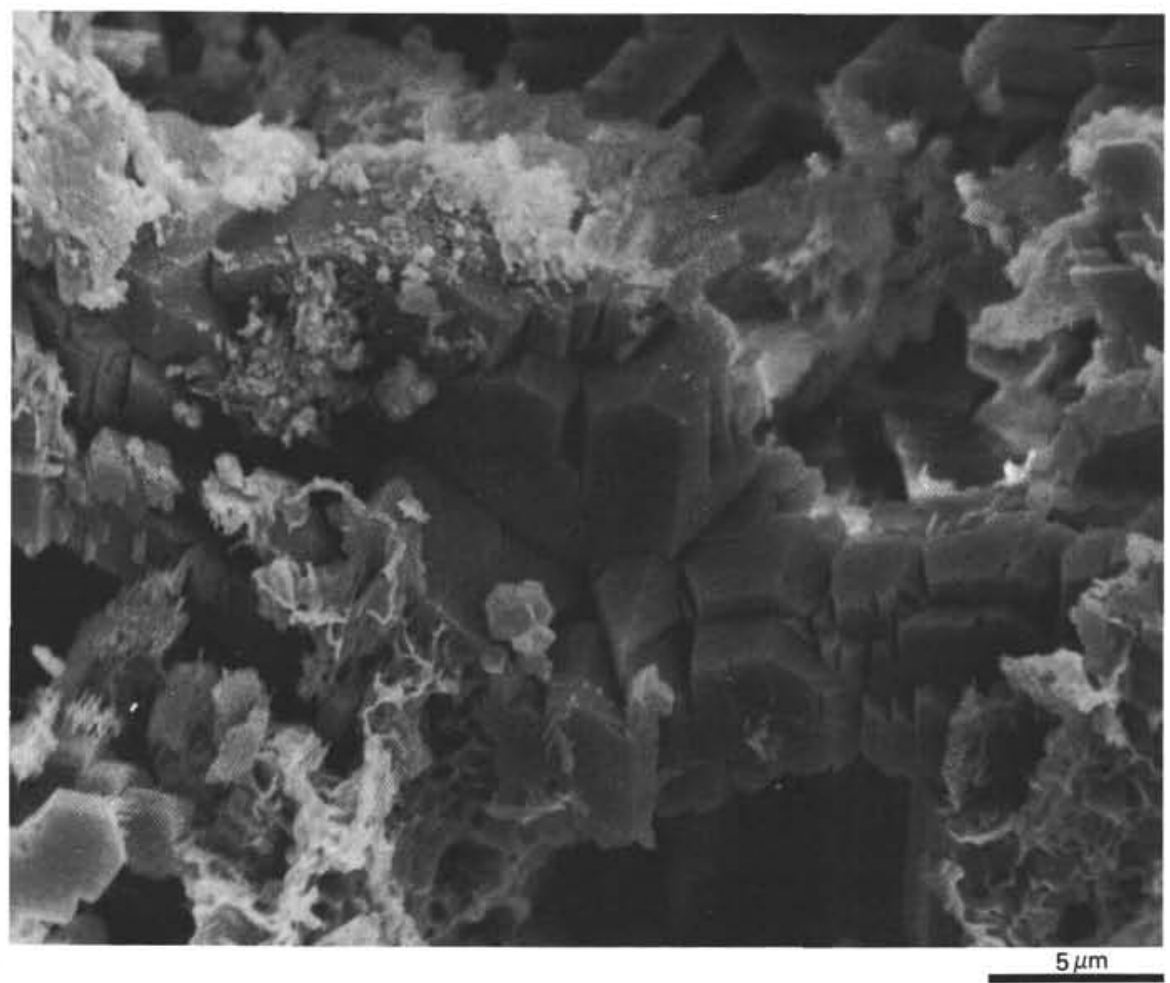

Figure 7. Zeolite [clinoptilolite(?)] in brown clay from Unit II, Sample 464-7-5, 130-132 $\mathrm{cm}$. Dark bar is about $5 \mu \mathrm{m}$ long.

continuing to Core 28 , the chert is mostly reddishbrown and dark reddish-brown. The reddish hue vanishes in chert near the bottom of Core 28 , and the remaining chert samples are commonly dark brownishgray.

Most of the chert is characterized by vugs filled with light-red and $\tan$ sliceous chalk or porcellanite, and light-brown to pink or white surface coatings of similar material. Color banding and mottling are common. Chert in Core 32 is coated with calcite crystals. Other crystalline overgrowths and veins in the lower cores are composed of very small quartz crystals.

We assume that the chert occurs interbedded with a softer material, probably chalk or marlstone, but the nature of this softer material is suggested only by a few recovered fragments; about half of the 23 cores from Unit III contain fragments of other sediment types. Light- to medium-brown porcellanite occurs in Core 11. Cores 12 through 18 contain fragments of siliceous limestone that are light gray, green, and blue. Another piece of light-colored porcellanite occurs in Core 27. Dark-red and brown limestone, marlstone, and nannofossil claystone occur in Cores 21, 29, 30, and 32. The clay content of the claystone and marlstone in Cores 29 and 30 is 70 to $90 \%$, decreasing to $55 \%$ in Core 32 . The soft interlayers therefore appear to be calcareous; they are light colored above about Core 20 and dark red below, the clay content increasing in the lower part of the section.

\section{Unit IV: Basalt}

Fragments of highly altered, fine-grained, gray basalt containing scattered feldspar microphenocrysts were obtained in Section 34,CC at a sub-bottom depth of 307.6 to 308.5 meters. One basalt fragment appears to be brecciated, the fractures being filled by green smectite. 
Thin-section studies indicate an intersertal texture and a primary mineralogy of approximately $35 \%$ plagioclase, $29 \%$ pyroxene, $25 \%$ glass, $10 \%$ opaque minerals, and $1 \%$ olivine. A variety of green and brown smectite minerals occur as pseudomorphs of the primary minerals. Euhedral crystal outlines indicate that olivine was one of the microphenocryst phases, along with plagioclase. Plagioclase is variably altered, and only a few remnants of pyroxene remain. The groundmass probably was variolitic tachylite that subsequently altered to smectite.

Major-, minor-, and trace-element data for the basalt from Hole 464 are consistent with these rocks being transitional tholeiites that have undergone low-temperature alteration by reaction with sea water (Seifert et al., this volume). Plagioclase compositions range from about $\mathrm{An}_{46}$ to $\mathrm{An}_{54}$ mole percent (Lee-Wong, this volume). From these data, it cannot be determined whether the tholeiite was erupted at a mid-ocean ridge or by intraplate volcanism.

\section{Conclusions}

Linear sedimentation rates can be calculated by combining the thickness of each unit with paleontologically determined ages of the boundaries (Table 3 ). Unit I, the clayey siliceous ooze and siliceous clay, was deposited at an overall rate of about $5.7 \mathrm{~m} / \mathrm{m} . \mathrm{y}$. , which is a normal rate for the deposition of siliceous oozes with high clay contents.

Unfortunately, we do not have good age control for Unit II, the pelagic-clay sequence. Our best data are from the study of ichthyoliths (Doyle and Riedel, this volume). If we arbitrarily assign an age of $75 \mathrm{~m}$.y. to the oldest brown clay, based on a "Late Cretaceous" age, then the calculated linear sedimentation rate is about 0.8 $\mathrm{m} / \mathrm{m} . \mathrm{y}$., which is typical of brown-clay deposition. If, however, we assume that the brown clay was deposited continuously between the top of Unit III ( $\sim 98$ m.y. ago) and the base of Unit I ( $~ 8$ m.y. ago), then the linear sedimentation rate for the $90 \mathrm{~m} . \mathrm{y}$. is only about $0.6 \mathrm{~m} / \mathrm{m} . \mathrm{y}$. , a low but possibly acceptable figure for brown-clay sedimentation if we assume that several hiatuses occur in Unit II.

Table 3. Approximate ages and linear sedimentation rates of sedimentary units recovered at Site 464 .

\begin{tabular}{|c|c|c|c|}
\hline $\begin{array}{l}\text { Lithologic } \\
\text { Unit }\end{array}$ & Geologic Age & $\begin{array}{l}\text { Thickness } \\
\text { (m) }\end{array}$ & $\begin{array}{l}\text { Sedimentation Rate } \\
(\mathrm{m} / \mathrm{m} . \mathrm{y} .)\end{array}$ \\
\hline IA & $\begin{array}{l}\text { late Pliocene to early } \\
\text { Pliocene }(2.25-3.5 \text { m.y.) }\end{array}$ & 15.3 & 12.2 \\
\hline IB & $\begin{array}{l}\text { early Pliocene } \\
(3.5-8 \text { m.y.) to late } \\
\text { Miocene }\end{array}$ & 17.3 & 3.8 \\
\hline II & $\begin{array}{l}\text { late Miocene to } \\
\text { late Cretaceous } \\
(8-75(?) \text { m.y. })^{\mathrm{a}}\end{array}$ & 52.9 & 0.8 \\
\hline III & $\begin{array}{l}\text { early Cenomanian to } \\
\text { early Albian/late Aptian } \\
\text { (98-108 m.y.) }\end{array}$ & 218.6 & 21.9 \\
\hline
\end{tabular}

a 75-m.y. age arbitrarily picked from "Late Cretaceous" age of ichthyoliths (Doyle and Riedel, this volume); if an age of $98 \mathrm{~m} . y$. is used for the base of Unit II, then a rate of $0.6 \mathrm{~m} / \mathrm{m} . \mathrm{y}$. is calculated.
Cenomanian to Albian (possibly upper Aptian) rocks of Unit III presumably are mostly chalks which grade down to clay-rich calcareous sediment and consist of at least 5 to $10 \%$ interbedded chert. The time of equator crossing of Site 464 is probably late Albian (100-103 m.y.), which corresponds to the upper two-thirds of Unit 3. These materials have a high linear sedimentation rate, which is normal for pelagic biogenic sediment. The few pieces of rock recovered from Core 29 ( $260 \mathrm{~m}$ subbottom) and below are nannofossil claystone and marlstone, and those above are chalk. Waters collected from the liners of Cores 11 to 20 contained well-preserved planktonic foraminifers of Albian age; none were found in the lower cores. This fragmentary information suggests that the lowermost 50 meters of Unit III were deposited near the shallow $(\sim 3 \mathrm{~km})$ middle Cretaceous $C C D$, south of the equatorial high-productivity zone, and the remainder of Unit III records the passage of Site 464 below the equatorial high-productivity zone.

\section{INTERSTITIAL-WATER GEOCHEMISTRY}

Because of poor recovery of unconsolidated and weakly consolidated sediments below Core 10 ( 89 meters), only three samples for interstitial water were collected. Analyses of these three samples are presented in Fig. 8. Values of $p \mathrm{H}$ are slightly lower than those for normal sea water and do not change significantly within the 75-meter sediment section sampled for interstitial water. Values for salinity, chlorinity, and alkalinity are slightly higher than those for normal sea water and exhibit slight decreases with depth. The inverse relationship between variations in $\mathrm{Ca}$ and $\mathrm{Mg}$, commonly observed in deep sea sediments, begins in Hole 464 at a depth of about 25 meters. Ca increases from about 12 $\mathrm{mmol} / \mathrm{l}$ to about $23 \mathrm{mmol} / \mathrm{l}$ between 25 and 75 meters, while $\mathrm{Mg}$ decreases from about $52 \mathrm{mmol} / \mathrm{l}$ to about 41 $\mathrm{mmol} / l$ within the same interval. Unfortunately, additional samples could not be collected to further define this trend, particularly as it relates to the diagenesis of $\mathrm{CaCO}_{3}$ and $\mathrm{SiO}_{2}$ at depth.

\section{PHYSICAL PROPERTIES}

For unconsolidated sediments of Cores 2 to 10 (clayey radiolarian ooze, diatom ooze, siliceous-fossil clay, and pelagic brown clay), wet-bulk density and, occasionally, sound velocity were measured by using the analog-GRAPE technique and Hamilton Frame Velocimeter, respectively. Thermal conductivity was also measured in two cores by using QTM. Because of poor sample recovery in the interval of Cores 11 to 34 , only a small portion of limestone, chert, and altered basalt was minicored for the measurements of 2-minute GRAPE and gravimetric wet-bulk densities, sound velocity, and thermal conductivity. All of the measured values of sound velocity, wet-bulk density, porosity, and thermal conductivity at room temperature are shown in Figure 9.

Because the measured specimens were very scarce, the data were simply averaged, and an interval velocity was estimated for the acoustic units (Table 4). In estimating the mean density and interval velocity in Litho- 


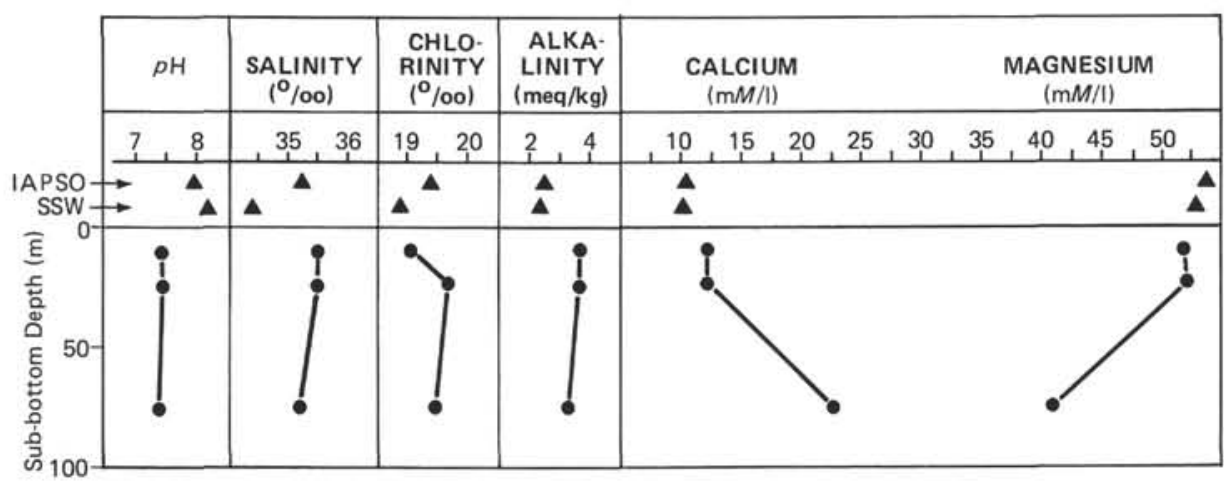

Figure 8. Interstitial-water geochemistry, Site 464.

logic Unit III (acoustic unit II), the sedimentary rock is assumed to be composed $95 \%$ of limestone $\left(2.0 \mathrm{~g} / \mathrm{cm}^{3}\right.$ and $2.2 \mathrm{~km} / \mathrm{s})$ and $5 \%$ of chert $\left(2.57 \mathrm{~g} / \mathrm{cm}^{3}\right.$ and 5.2 $\mathrm{km} / \mathrm{s})$.

\section{CORRELATION OF SEISMIC-REFLECTION PROFILES WITH DRILLING RESULTS}

Three acoustic units can be identified on the seismicreflection profile (Fig. 10). Velocity measurements on laboratory samples from acoustic unit I are about the same as that calculated for the interval velocity. In acoustic unit II, the sample velocities are much higher, because chert was a major component of recovered cores, although it apparently made up only a small part of the drilled section (Table 4). The interval velocity calculated from the two-way times still is lower than the velocity calculated from the formula (Table 4), which might mean that there is more chalk than limestone in the section.

The low velocity for basalt probably is caused by extensive alteration. Primary components-including pyroxene, plagioclase, and glass-are replaced by smectite.

\section{BIOSTRATIGRAPHY}

\section{Summary}

At Site 464, the sedimentary section (Fig. 11) was cored continuously to a sub-bottom depth of 307.6 meters. The upper Cenozoic sequence is typified by an abundance of siliceous microfossils in Cores 2 to 5 , and is essentially barren in the brown clays of Cores 5 to 10 . The recovered sediment of the Lower Cretaceous sequence is mainly chert, with an occasional layer or coating of non-indurated sediment containing nannoplankton, foraminifers, and radiolarians. The section consists, from top to bottom, of the following:

1) 32.6 meters of upper Pliocene to lower Miocene radiolarian and siliceous-fossil oozes and siliceous-fossil clays (Cores 2-5). The radiolarian and diatom assemblages are diverse and well preserved, showing a mixing of water masses of (sub)tropical and high-latitude belts. This mixture permits recognition of both the tropical zonation and the high-latitude zonation of the two fossil groups. The mixing of indicators of bordering water masses suggests an oceanographic regime similar to that of the present time for this latitude. In Cores 2 to 4 , moderately to strongly etched nannofossil assemblages and exceptionally rare planktonic-foraminifer specimens indicate that deposition was just above the CCD for nannoplankton, and below the CCD for planktonic foraminifers. Deep-water calcareous benthic forms (more resistant to solution than planktonic foraminifers) were recovered from this interval. Nannofossils, radiolarians, and diatoms provide age determinations.

2) 52.9 meters of Upper Cretaceous to lower Miocene brown clays (Cores 5-10), almost barren of microfossils. One poorly preserved but age-determinate assemblage of radiolarians was recovered from Core 7, giving an age of 4 to $6.5 \mathrm{~m}$.y. The preservation (etching) is such that the assemblage does not look like a contaminant from above. In Sample 10,CC, a recrystallized Cretaceous radiolarian fauna is considered reworked. Age assignments for this interval based on ichthyoliths are given by Doyle and Riedel (this volume).

3) A probable lacuna occurs at 89 meters (between Cores 10 and 11).

4) 218.6 meters (Cores 11-33) of red-brown chert (interval probably mostly softer sediments) extends to the base of the sediment column. Very low recovery includes mostly chert and small amounts of the intercalated non-indurated lithologies. The small scrapings of sediments on and between the chert fragments in Cores 11 to 24 contain fairly well-preserved nannofossils of Albian to Cenomanian age. Farther down-core, the nannofloras show dissolution features, until precise age determinations are no longer possible in Cores 29 to 33. Albian planktonic foraminifers were recovered from core-water samples and one core-catcher sample in Cores 13 to 33. Mostly deep-water benthic foraminifers were found, with the exception of a sample in Core 27 with large benthic foraminifers of a neritic environment, most likely redeposited in deeper water. Occasionally, poorly preserved radiolarian faunas of indeterminate age were recovered from the larger pieces of soft sediment, or from the water in the core liners. The age of sediment at the bottom of Hole 464 cannot be determined precisely, but it is considered to be early Albian or slightly older.

\section{Nannoplankton}

Nannofossils are present in Lithologic Units I and III, in Cores 1 to 4 and 11 to 32, respectively. In the siliceous oozes of Unit I are moderately to strongly etched 


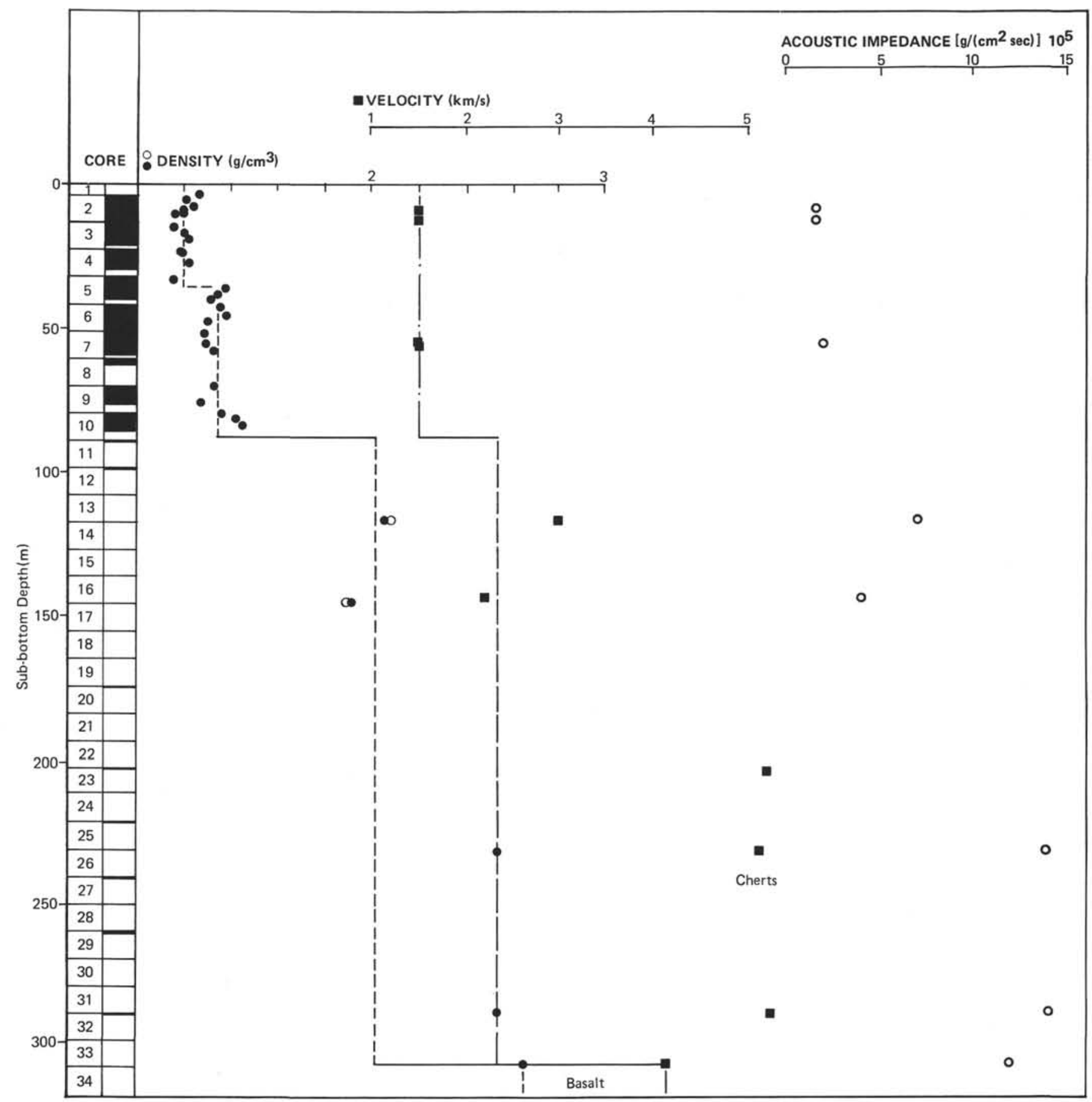

Figure 9. Shipboard measurements of porosity, compressional-sound velocity, acoustic impedance, and wet-bulk density, Hole 464.

Table 4. Physical properties of acoustic and lithologic units, Site 464.

\begin{tabular}{|c|c|c|c|c|c|c|}
\hline $\begin{array}{l}\text { Lithologic } \\
\text { Unit }\end{array}$ & $\begin{array}{c}\text { Acoustic } \\
\text { Unit }\end{array}$ & $\begin{array}{l}\text { Sub-bottom } \\
\text { Depth } \\
\text { (m) }\end{array}$ & $\begin{array}{l}\text { Density } \\
\left(\mathrm{g} / \mathrm{cm}^{3}\right)\end{array}$ & $\begin{array}{c}\text { Sample } \\
V_{\mathrm{p}} \\
(\mathrm{km} / \mathrm{s})\end{array}$ & $\begin{array}{c}\text { Interval } \\
V_{\mathrm{p}} \\
(\mathrm{km} / \mathrm{s})\end{array}$ & $\begin{array}{c}\text { DT } \\
\text { (sec) }\end{array}$ \\
\hline I, II & I & $0-89$ & $1.2-1.34$ & 1.52 & 1.47 & 0.13 \\
\hline III & II & $89-307.6$ & $2.35^{\mathrm{a}}$ & 2.35 & 2.08 & 0.21 \\
\hline IV & III & $307.6-308.5$ & 2.65 & 4.10 & - & - \\
\hline
\end{tabular}

a Unit II measurements are biased by chert samples; it is assumed that the unit is $95 \%$ limestone and $5 \%$ chert; the value was obtained from the following formula: $(2.2 \mathrm{~km} / \mathrm{s} \times 0.95)+(5.2 \mathrm{~km} / \mathrm{s} \times 0.05)=2.35 \mathrm{~km} / \mathrm{s}$ (limestone $\left.V_{\mathrm{p}} \times \%\right)\left(\right.$ chert $\left.V_{\mathrm{p}} \times \%\right)$ nannofossil assemblages assignable to standard zones of early and late Pliocene age. All nannofossils are removed by dissolution by Core 4 , Section 2 . Nannofossils are absent in the non-calcareous pelagic clay of Unit II. After a probable hiatus at 89 meters, the semi-indurated sediments on and between the chert pieces of Unit III yielded nannofossils of varying abundance and preservation. Assemblages from Cores 11 to 24 are readily assignable to the Albian to Cenomanian, but it becomes increasingly difficult down-core to give zone and age determinations, because of selective removal of index species by dissolution. 

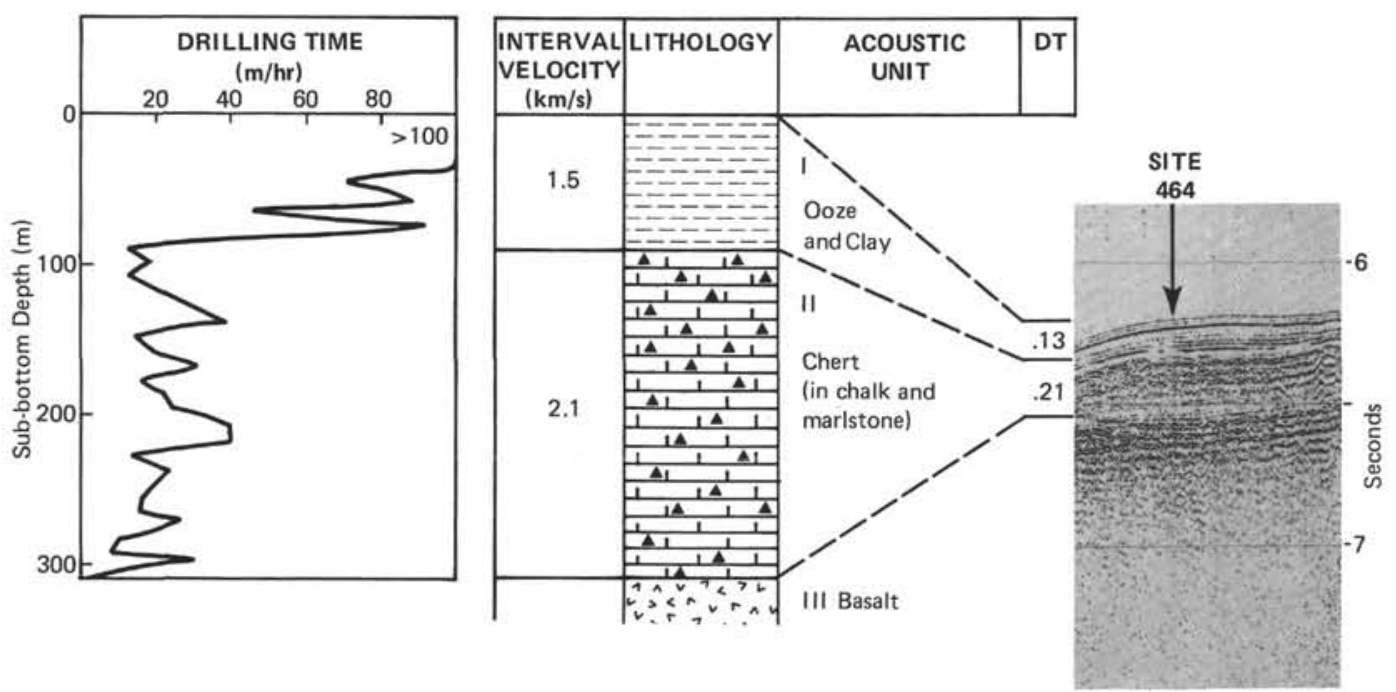

Figure 10. Correlation of seismic-reflection profile with drilling results. Interval velocity is calculated from thickness of lithologic units.

\section{Cenozoic}

A sequence of lower Pliocene to upper Pliocene nannofossil zones has been observed from Cores 2 to Section 4-2. In addition, small traces of sediment in Core 1 (and the two abortive cores before them) were sampled. Most of these belong to the Pseudoemiliania lacunosa Zone (NN19) of the early Pleistocene. From Core 1, a small smear of sediment on a bottom tooth of the core catcher contained discoasters diagnostic of the Discoaster surculus Zone (NN16). Sampling the mud line at this site was difficult, and we infer that an unknown thickness of upper Pliocene through Pleistocene sediments occurs above Core 2.

The first six sections of Core 2 can be assigned to the Discoaster surculus Zone. Samples from Sections 2-6 to 4-1 belong to the Discoaster asymmetricus (NN14)/ Reticulofenestra pseudoumbilica (NN15) zonal interval. Samples in Sections 4-1 to 4-2 are assigned to the Amaurolithus tricorniculatus (NN12)/Ceratolithus rugosus (NN12) zonal interval. A more-detailed zonation in the Pliocene is hampered by the rarity of ceratolithids important to detailed zonation. Since they are solutionresistant, like discoasters, their rarity must be explained by some paleoenvironmental factor, such as their being more restricted to tropical waters.

Sections 4-2 to $10, \mathrm{CC}$ are barren of calcareous nannofossils. The nannofossil assemblages recovered from Cores 1 to 4 are moderately to strongly etched. Most of the small, more-delicate coccoliths are almost completely dissolved, and even some of the structurally stronger, larger coccoliths are etched or fragmented.

\section{Mesozoic}

Abundant to rare (predominantly abundant) but poorly preserved calcareous-nannofossil assemblages are found throughout the Lower Cretaceous and lowermost Upper Cretaceous. A sequence of five nannofossil zones or zonal intervals has been recognized within Lithologic Unit III:

1) Uppermost Albian to Cenomanian (464-11-1, 68-69 cm, to 464-18,CC, 22-23 cm), Lithraphidites alatus Zone.

2) Upper Albian (464-18,CC, base, to 464-24-1, $15-16 \mathrm{~cm})$, Eiffelithus turriseiffeli Zone.

3) Middle Albian (464-25,CC to 464-26-1, 75-76 $\mathrm{cm})$, Prediscosphaera cretacea Zone.

4) Lower Albian (464-27-1, 25-26 cm), Parhabdolithus angustus Zone.

5) Lower Cretaceous $(464-28-1,25-26 \mathrm{~cm}$, to $464-$ $32-1,18-19 \mathrm{~cm})$. Core 28 is barren of calcareous nannofossils. Cores 29 to 32 generally contain abundant nannofossils which are very poorly preserved. As a result of strong dissolution, all index species are missing, and only solution-resistant species like Watznaueria barnesae, Manivitella pemmatoidea, Parhabdolithus embergeri, and Lithraphidites carniolensis are present. The absence of index species makes it impossible to determine an exact interval within the Lower Cretaceous. Probably this third interval is not older than early Aptian, because Nannoconus colomii, a very solution resistant species which has its last occurrence at the top of the Barremian, is not present.

\section{Foraminifers}

\section{Coarse Fraction ( $>63 \mu \mathrm{m}$ ) Components; Abundance and Preservation of Foraminifers}

A visual estimate of the relative abundance of main components of the sediment coarse fraction is presented in Appendix C. The coarse fraction of Core 1 is exclusively pumice. In the siliceous oozes of Cores 2 through 5, biogenic silica is the main component of the coarse fraction. In this interval, radiolarians are very abundant, and diatoms and sponge spicules are common, whereas volcanic glass, phillipsite, iron oxide, fish 


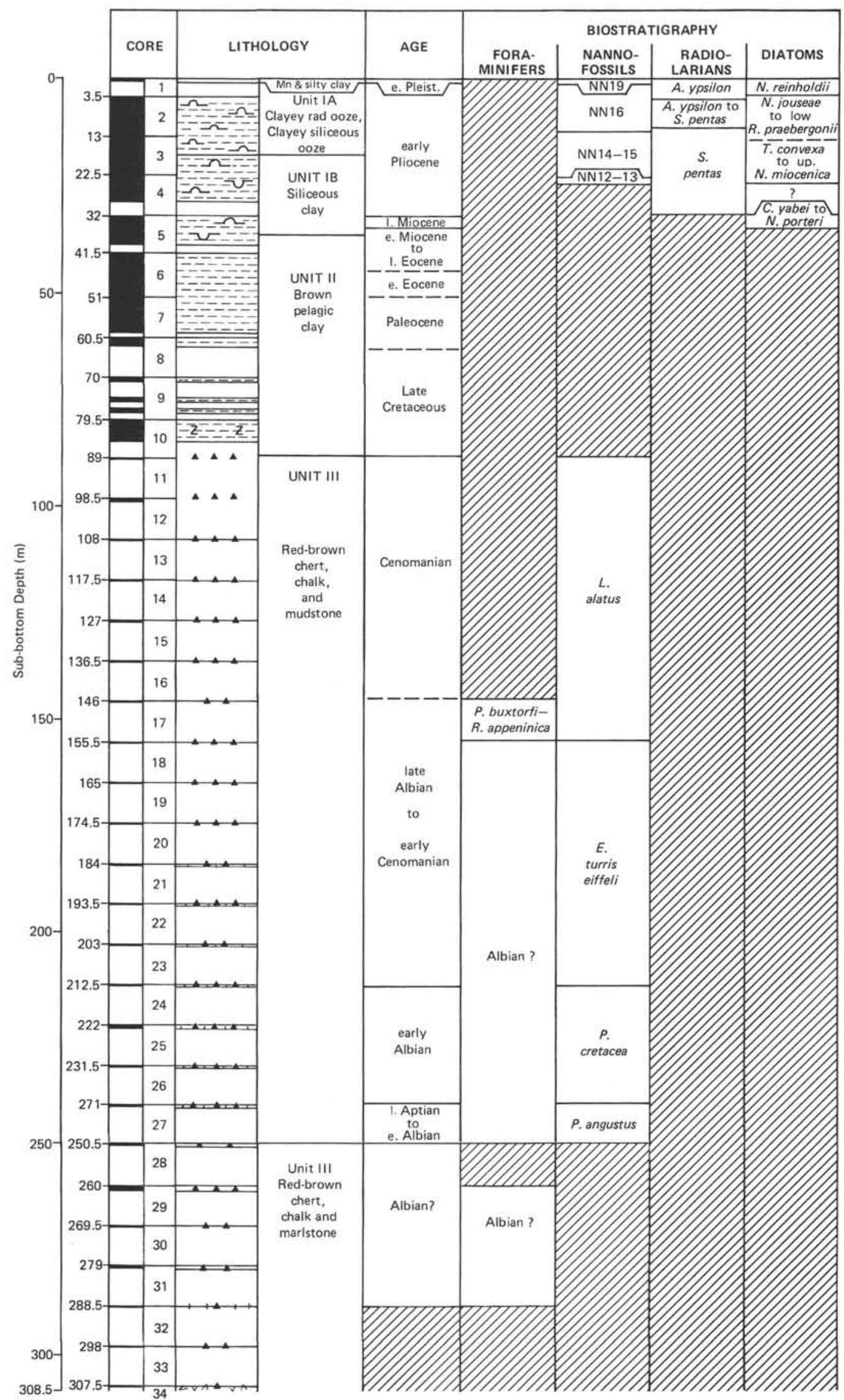

Figure 11. Biostratigraphy of Hole 464 . 
fragments, and calcareous benthic foraminifers (more resistant to solution than planktonic foraminifers) are rare. Only 3 individual planktonic foraminifers were found in this interval.

The remainder of the section yielded a very small amount of coarse fraction. In the brown clays of Core 6 through 8 , clay aggregates and iron oxide are the main components of the coarse fraction, whereas fish fragments and arenaceous benthic foraminifers are rare.

In Cores 10 through 27, recovered sediments are mainly chert, with only an extremely small amount of iron-hydroxide-stained chalk. This chalk and the water flowing out of the core barrels yielded abundant chert fragments and iron-stained chalk aggregates and common to abundant, moderately well-preserved planktonic foraminifers.

From Core 28 down to the bottom of the hole, calcareous material is virtually absent, and radiolarians and chert dominate the coarse fraction.

\section{Foraminifer Assemblages}

\section{Cenozoic}

Only three individual planktonic foraminifers were found. One specimen of Globigerinita glutinata occurred in Section 2,CC. This species is known to range from the Miocene to the Recent. Two individuals, one each of Sphaeroidinellopsis seminulina and of Sphaeroidinellopsis subdehiscens, occurred at 464-4-1, 118-122 $\mathrm{cm}$, indicating that this horizon is middle Miocene to lower Pliocene (interval from N13 to N19).

The calcareous deep-water benthic-foraminifer fauna in Cores 2 through 4 includes common Epistominella exigua and rare Cassidulina subglobosa, Laticarinina pauperata, Oridonali sp., Melonis pompiloides, Gyroidina sp., and Pyrgo sp. The benthic-foraminifer fauna of Cores 6 through 8 is composed exclusively of tubular and gnarled arenaceous forms.

\section{Cretaceous}

Cretaceous foraminifers were recovered in core-water samples and one core-catcher sample from Cores 17 through 33 . The foraminifers in the water samples probably came from sediment originally intercalated between the chert lenses, but not recovered. In Core 23 it was possible to scrape the core liner and recover a small amount of the sediment.

The small foraminifer faunas were only moderately well-preserved and contained small planktonic and deep-water benthic foraminifers; these foraminifers were included in a matrix of chert and mineral particles. Planktonic populations were dominated by the small hedgerellids, some Globigerinelloides sp. and Ticinella sp. cf. $T$. primula. The zonal index fossils for the late Shackoina molinensis and S. cenomana Zones were present in Section 17,CC.

Section $27-1,25 \mathrm{~cm}$, contained very large calcareous and agglutinated benthic foraminifers typical of a neritic environment, along with the small, but moderately well-preserved planktonic assemblage. This suggests redeposition of neritic sediments into deeper water.

\section{Radiolarians}

At Site 464, Cenozoic radiolarians are abundant and generally well preserved, whereas Cretaceous radiolarians, although occasionally common, are poorly preserved.

\section{Cenozoic}

Core 1 consists only of a manganese nodule in which the sediment nucleus was barren. However, water collected from the core barrel produced an abundant and well-preserved radiolarian fauna. In spite of the moderately high latitude, the assemblage consists of a mixing of radiolarians that are indicators of different water masses. The following are present (after Casey, 1971): equatorial central shallow radiolarians such as $L$. maritalis, $P$. praetextum, and $P$. trilobum; equatorial radiolarians such as $P$. murrayana and $A$. cineraria; transitional central radiolarians such as $P$. circumtexta and $S$. erucosa; subarctic intermediate radiolarians such as C. profunda and C. laguncula; and transitional Arctic radiolarians such as $P$. hirundo.

The diversity of this assemblage permits the recognition of both the high-latitude zonation (Hays, 1970) and the equatorial zonation (Nigrini, 1971). The age of the fauna is early Pleistocene (E. matuyamai Zone from Hays, or $A$. ypsilon Zone from Nigrini).

In Sections 2-1 to 2-5, the fauna is lower Pleistocene (E. matuyamai Zone) with reworked lower Pliocene ( $S$. pentas Zone).

In Cores 2 to 5 (whose core catcher has a rare and poorly preserved fauna) the radiolarians indicate an early Pliocene age ( $S$. pentas Zone).

Cores 8 and 9 are barren, except for the core catcher of 7 , where a very poorly preserved assemblage with $S$. peregrina gives a late Miocene to early Pliocene age ( $S$. peregrina or $S$. pentas Zone).

In the core catcher of Core 10, there appears an undateable, reworked Cretaceous fauna. All the specimens are recrystallized, and index radiolarians such as Spongosaturnalis are fragmented.

\section{Mesozoic}

In the rest of the hole (Cores 11-33), common but very poorly preserved radiolarians are present. Always recrystallized, these faunas are essentially composed of non-diagnostic genera such as Amphipyndax, Dictyomitra, and cryptocephalic Nasselaria. The poor preservation does not permit age determinations.

\section{Diatoms}

At Site 464, diatoms are present in Cores 1 through 5, where the lower Pliocene and upper Miocene are represented by a fairly diverse assemblage.

Core 1 consists of a manganese-encrusted bleb of sediment, with moderately well-preserved but fragmented diatoms. The core falls within the early Pleistocene Nitzschia reinholdii Zone, equivalent to the Actinocyclus oculatus Zone of the North Pacific (1.0-1.8 m.y.).

Core 2 through Core 3, Section 2 belong to the Nitzschia jouseae Zone of the early Pliocene, equivalent to 
the upper Denticula kamtschatica or lower D. seminae fossilis/D. kamtschatica Zone (3.0-4.6 m.y.).

Between Core 3, Section 3, and Core 4, Section 2, there are few useful age-diagnostic species. The absence of $N$. jouseae, combined with the presence of $D$. kamschatica, suggests an age between 4.6 and 6.2 m.y. (earliest Pliocene to late Miocene D. kamschatica Zone, correlative with the $T$. convexa and upper $N$. miocenica Zones).

Core 5, Section 3, contains D. hustedtii, T. burckliana, and $N$. porteri, which puts it in the late Miocene $N$. porteri Zone. If $T$. burckliana is in situ (not reworked), then the sample falls in the lowermost Epoch 7 or Epoch 8 (8-9 m.y.); if, on the other hand, only $D$. hustedtii is reliable, the sample could be as young as 5 m.y. (Mio-Pliocene boundary). T. burckliana is very rare, and $N$. porteri fairly rare. Core 5 is certainly within the late Miocene.

Below Core 5, Section 3, diatoms become very rare, and only non-diagnostic species are present.

Warm-water, subtropical species predominate through this interval, but subarctic species are also represented, especially in the lower part of Core 2, which may indicate a cooling interval. Preservation decreases with increasing clay content; Cores 2 to 4 are well preserved, and Core 5 shows rapidly deteriorating preservation.

\section{SEDIMENTATION RATES}

Accumulation rates at Site 464 have been estimated using the time scales agreed upon for Leg 62 . Each fossil group that contains data contributing to an age determination is plotted separately on Figure 12. In Figure 12 , the accumulation curve is determined mainly from the nannoplankton data; the detailed inset for the upper Miocene to upper Pliocene sediments contains all the available data from nannoplankton, diatoms, and radiolarians.

The most-detailed data concerning zonal boundaries are from the nannoplankton. The boundaries for the Discoaster asymmetricus (NN14)/Reticulofenestra pseudoumbilica (NN15) zonal interval can be determined accurately and provide an accumulation rate of $11 \mathrm{~m} /$ m.y.

A summary of accumulation-rate data for the Pliocene and Albian from Sites 464 and 463 is summarized below:

\begin{tabular}{lrr}
\hline Site & Pliocene $(1.8-5 \mathrm{~m} . \mathrm{y})$. & Albian $(100-108 \mathrm{~m} . \mathrm{y})$. \\
\hline 464 & $11 \mathrm{~m} / \mathrm{m} . \mathrm{y}$. & $12 \mathrm{~m} / \mathrm{m} . \mathrm{y}$. \\
463 & $3.5 \mathrm{~m} / \mathrm{m} . \mathrm{y}$. & $10 \mathrm{~m} / \mathrm{m} . \mathrm{y}$. \\
\hline
\end{tabular}

The accumulation rates for the Pliocene at Site 464 are noticeably higher than at Site 463 . For a higher accumulation rate at Site 464 than at Site 463 during the Pliocene, higher productivity of siliceous organisms seems necessary. Colliding water masses of the transition zone probably result in blooms of diatoms and radiolarians, whose overabundance must be sufficient to compensate for the decrease in accumulation of most calcareous microfossils. Terrigenous clays also increase the sedimentation rate.

A comparison of the accumulation rates for Sites 463 and 464 in the Albian does not confirm the model of equatorial crossing and high productivity (Lancelot and Larson, 1975). According to their model, Site 464 should have crossed the equatorial high-productivity zone between 100 and 110 m.y. ago, during the Albian time. The Albian accumulation rate at Site 464, how-

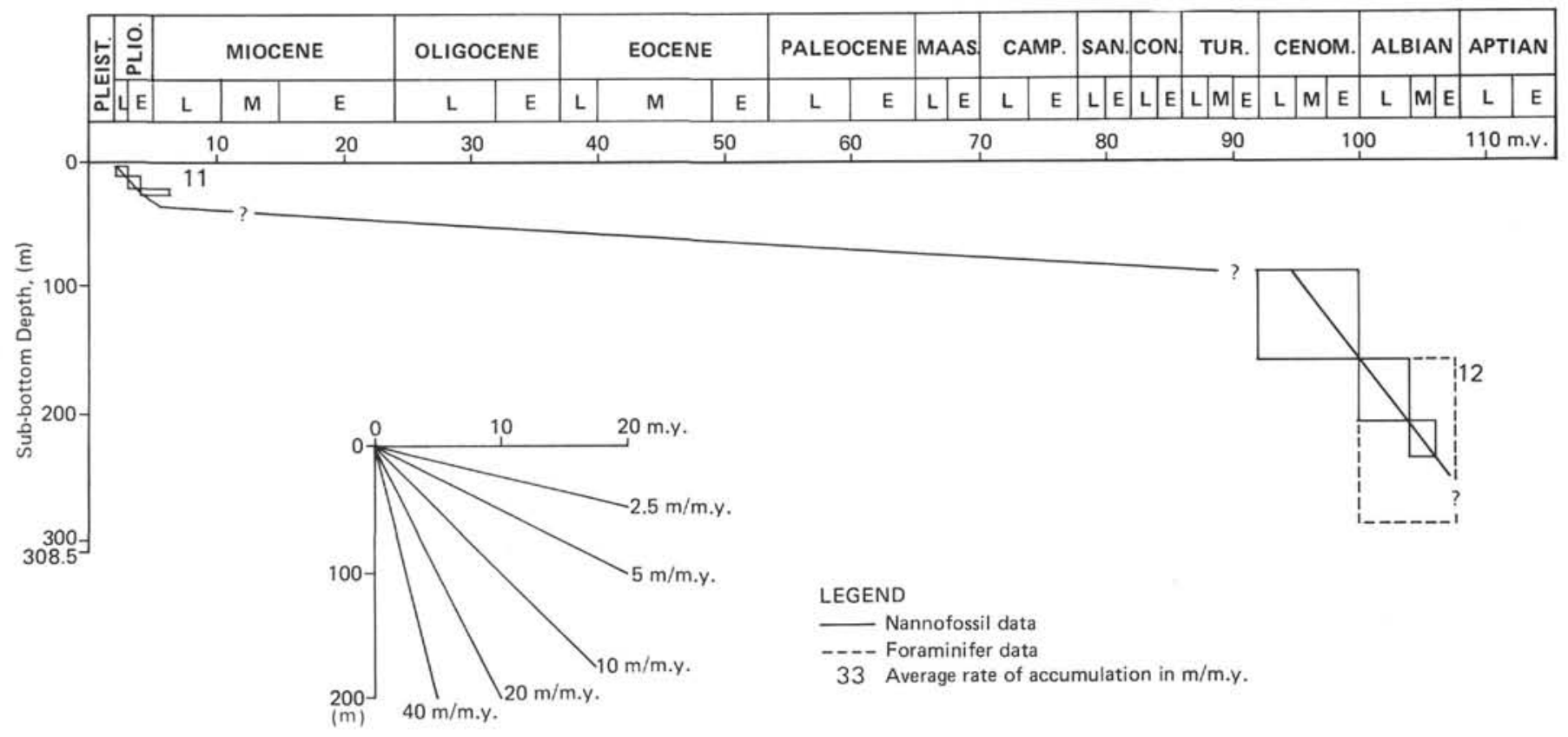

Figure 12. Sedimentation-rate diagram for Hole 464. 
ever, is similar to that at Site 463 . It is possible that other factors affected the relatively high biogenic-sedimentation rate at Site 463 .

\section{SUMMARY AND CONCLUSIONS}

Major results of drilling at Site 464 are (1) recovery of tholeiitic basalt at the base of the hole, (2) penetration of a thick, mostly Albian, chert, chalk, and marlstone sequence, (3) recovery of a thick section of pelagic clay that ranges in age from Late Cretaceous to late Miocene, and (4) recovery of a Neogene sequence of siliceous clay and clayey siliceous ooze deposited under the transition zone between subarctic and subtropical water masses. A site-summary diagram is given in Figure 13.

The basalt marks acoustic basement for the airgun single-channel seismic-reflection profiles. Total recovery was only $16 \mathrm{~cm}$, and the rocks are highly altered. Most primary components are partially or wholly replaced by smectite. Textures are both variolitic and intersertal, which suggests that parts of a chilled margin were recovered. Major minerals are plagioclase $\left(\mathrm{An}_{45^{-}}\right.$ $\mathrm{An}_{54}$ ), clinopyroxene (replaced), glass and olivine (both replaced by smectite), and opaque minerals. The tholeiitic nature of the basalt is confirmed by trace elements, particularly the rare earths (Seifert et al., this volume). Alteration apparently mobilized significant proportions of the major elements. It is not clear if the basalt is part of a pillowed flow, or the chilled margin of a sill. The flatness of acoustic basement and the possible acoustic layering seen on the seismic-reflection profiles suggest that the basalt is the top of a layered sequence. It may be a pile of volcanic flows and intercalated sediments, or the layering, if real, may represent a sill-sediment sequence. Alternatively, the layering may be an acoustic artifact caused by a velocity inversion where altered basalt is overlain by limestone. The chemical data are insufficient to distinguish the geological setting, and the basalt may be either a mid-ocean-ridge effusive or the product of intraplate volcanism.

The oldest sediment overlying the basalt consists of red and brown chert which apparently is intercalated with marlstone, chalk, and claystone. Because of the ubiquitous chert, the other lithologies were washed out of the hole during coring. There is apparently a high percentage of red claystones near the basalt contact, but it is not clear whether these are entirely pelagic or if they have a significant amount of metalliferous components, like those observed at many deep-sea drill sites just above the igneous rocks.

Because of the poor preservation of all fossil groups, the age of oldest sediment cannot be determined precisely; Cepek (this volume) reports that it can be no older than early Aptian. In order to determine an approximate absolute age for the oldest sediment, we calculated the linear sedimentation rate for the well-dated middle and late Albian and extrapolated to the base of the hole. Based on our calculations, the age of the oldest sediment is about 112 m.y., which is early Aptian according to van Hinte (1976).

The poor recovery of representative lithologies in the oldest sediment sequence (Unit III) and the ubiquitous chert biased our interpretations of that unit's sedimentology. However, drilling records, calculated interval compressional-wave velocities, microfossil-rich water from some of the core barrels, and the fragments of chalk, marlstone, and claystone indicate that chert is not the dominant lithology; it probably constitutes only 5 to $10 \%$ of the unit.

A 52.9-meter-thick pelagic clay (Unit II) overlies Unit III. An absence of microfossils greatly hindered our shipboard interpretations, but later shore-based studies of ichthyoliths (Doyle and Riedel, this volume) show that the brown-clay unit records a long period of sedimentation from the Late Cretaceous to early Miocene (late Miocene according to diatoms). The pelagic clay unit is similar to other pelagic-clay units elsewhere in the world's oceans, as indicated by the high smectite content of the clay-mineral fraction, and by the abundance of metals (Dean, this volume).

The youngest unit is a mixture of siliceous microfossils and clay; some calcareous nannofossils occur in the upper parts. Age of sampled sediment ranges from late Miocene to early Pleistocene. Younger Pleistocene and Holocene sediments probably were lost during attempts to core the mud line. The presence of manganese nodules in the first core suggests that nodules may be abundant on the sea floor in the area around Site 464.

Site 464 is situated well below the modern local CCD, and apparently has been below the CCD since some time in the Late Cretaceous. According to Thierstein (1979), the CCD in the Pacific was shallow (about $3.4 \mathrm{~km}$ ) during the mid-Cretaceous, and data from the Atlantic (Thiede, 1979) are similar. If we assume that Site 464 was created at a depth of about $2.5 \mathrm{~km}$ along a midocean spreading ridge, then using the general subsidence curve of Sclater et al. (1971) we can calculate that Site 464 subsided $0.9 \mathrm{~km}$ in about $9 \mathrm{~m}$.y. If the age of basement is $112 \mathrm{~m} . \mathrm{y}$., then the site could have subsided below the CCD by 103 m.y. ago, during the late Albian. The CCD, however, probably was depressed during the deposition of Albian sediments, because of the high rate of calcareous biogenic sedimentation. This would suggest that the CCD was deeper than $3.4 \mathrm{~km}$, and that the site was younger when it finally passed through the CCD. The 103-m.y. age is relatively close to the age of youngest sediment in Unit III, and if the CCD passage were delayed by 3 to $5 \mathrm{~m}$.y., as suggested, then there is a good correlation between the expected CCD crossing and the age of youngest calcareous sediment in the unit.

From the available data, it is reasonable to conclude that no hiatus occurs between Units II and III. Rather, the transition from calcareous sediments to pelagic clay probably took place when the site subsided below the local CCD. There may be some hiatuses in the pelagicclay unit, but if sedimentation were continuous from the mid-Cretaceous through the early Miocene, then a linear sedimentation rate of about $0.6 \mathrm{~m} / \mathrm{m}$.y. is calculated. This rate is a somewhat low, but acceptable, value for pelagic-brown-clay deposition. We believe, however, that several hiatuses occur in the section.

The site likely formed south of the Equator and moved north during the Albian under the fertile equato- 


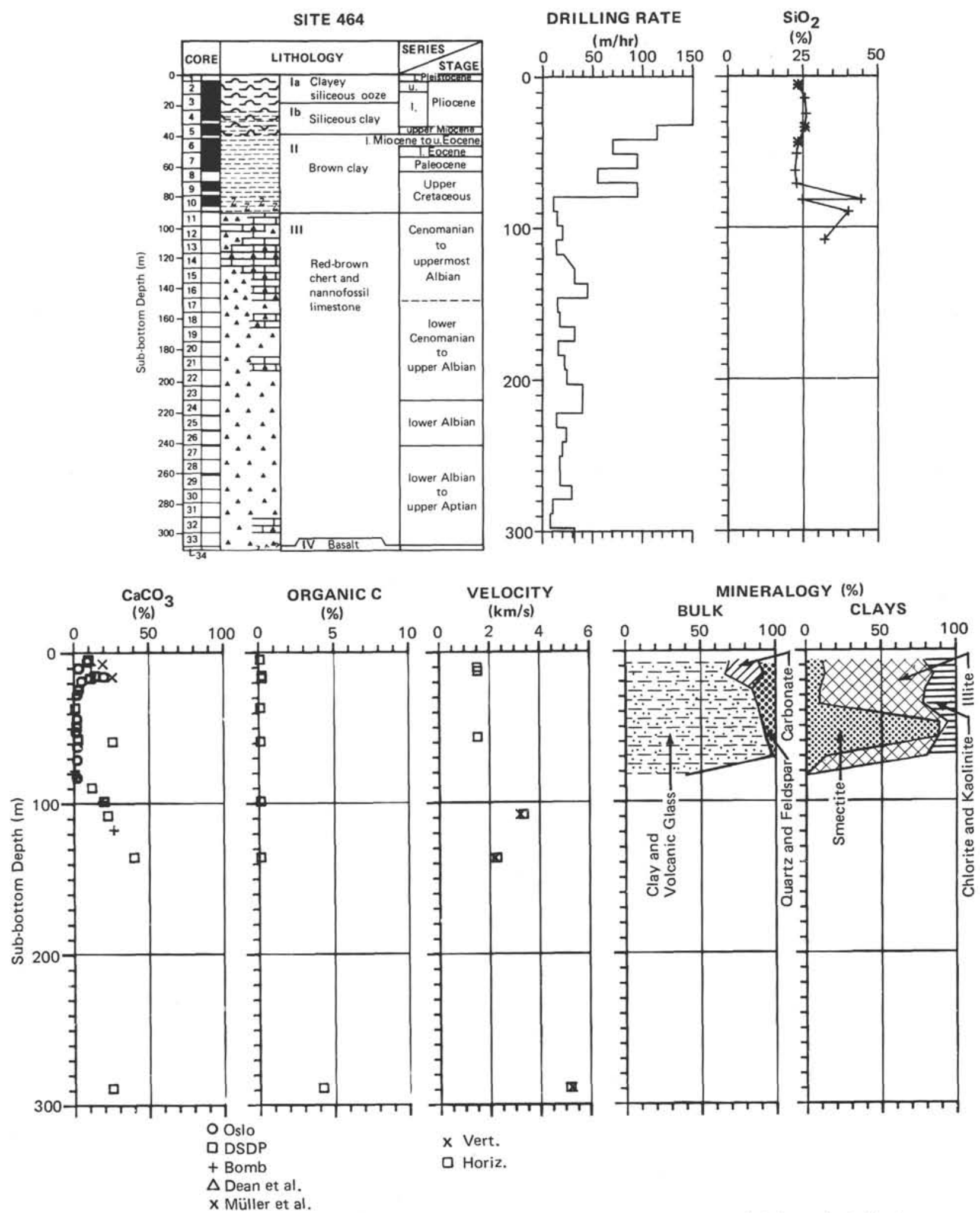

Figure 13. Site-summary chart, Site 464 , northern Hess Rise. The data for the summary are compiled from the following sources: $\% \mathrm{CaCO}_{3}$ and $\%$ organic carbon from Dean (this volume); density, $\%$ porosity, water content ( $\%$ water), and sound velocity from Appendix D (this chapter) and Fujii (this volume); \% sand, silt, and clay from Appendix E (this chapter); and clay mineralogy from Appendix C (this chapter) and Nagel and Schumann (this volume). 
rial surface water. This interpretation agrees with the models of both van Andel (1974) and Lancelot and Larson (1975). The high sedimentation rate, the thickness of the Albian sediments, and the common chert layers are related to the site's crossing of the mid-Cretaceous Equator. The preservation of calcareous material was also enhanced during Albian time, because the CCD was depressed under the equatorial current regime relative to other areas of the ocean.

The youngest unit was deposited under the transitional zone between subarctic and subtropical surfacewater masses and contains a diverse fossil assemblage of diatoms, calcareous nannofossils, silicoflagellates, radiolarians, and some benthic-foraminifer remains; feldspar, quartz, and kaolinite represent terrigenous components. Micronodules, fish debris, and volcanic glass were observed in trace amounts.

Physical-property measurements also were hindered by the poor recovery. Wet-bulk densities, however, show a close correlation with lithologic units. Densities are $1.2 \pm 0.03 \mathrm{~g} / \mathrm{cm}^{3}$ in Unit $\mathrm{I}, 1.34 \pm 0.05 \mathrm{~g} / \mathrm{cm}^{3}$ in Unit II, $2.03 \mathrm{~g} / \mathrm{cm}^{3}$ in Unit III, and $2.65 \mathrm{~g} / \mathrm{cm}^{3}$ in the basalt in Unit IV. Velocity $\left(V_{\mathrm{p}}\right)$ measurements on samples from the top 89 meters (Units I and II) agree fairly well with velocities calculated from seismicreflection records. Samples from lithologic Unit III have high velocities because only measurements on chert samples were completed. Estimating that the unit is made up $95 \%$ of limestone, however, we obtain an interval velocity of about $2.08 \mathrm{~km} / \mathrm{s}$. The low velocity for basalt $(4.1 \mathrm{~km} / \mathrm{s})$ is caused by the alteration effects.

The geologic history of Site 464 on northern Hess Rise can be interpreted by using existing models of vertical and horizontal movements of the Pacific Plate. Vertical movement (subsidence) controlled the change from calcareous sediment to pelagic-clay in the midCretaceous, and horizontal motion influenced the types of sediments because of movement under different surface-water regimes. The recorded geologic history probably began with the extrusion of basalt along or near a mid-ocean-ridge crest south of the Equator. Sedimentation began in the Aptian or early Albian, and calcareous and siliceous microfossils were deposited rapidly as the site passed under the very fertile surface water of the equatorial zone. Some clay also was deposited, but the origin of this material is unknown. As the site subsided and moved north, it passed through the CCD during the Cenomanian, and pelagic clay accumulated until the middle Miocene. During the late Miocene to Pleistocene, the site passed under more-fertile surface water, where subtropical and subarctic water masses mix, leading to deposition of both calcareous and siliceous microfossils. The site also approached North Pacific land masses, and some terrigenous material was brought to the site by winds. Dispersed volcanic glass indicates that explosive volcanism was occurring along the Pacific rim island arcs.

\section{REFERENCES}

Berger, W. H., 1973. Cenozoic sedimentation in the eastern tropical Pacific. Geol. Soc. Am. Bull., 84:1941-1954.

Casey, R. E., 1971. Radiolarians as indicators of past and present water masses. In Funnell, B. M., and Riedel, W. R. (Eds.), The Micropaleontology of Oceans: Cambridge (Cambridge Univ. Press), pp. 331-341.

Chase, T. E., Menard, H. W., and Mammerickx, J., 1971. Topography of the North Pacific: La Jolla (Univ. Calif.).

Hays, J. D., 1970. Stratigraphy and evolutionary trends of Radiolaria in North Pacific deep sea sediments. Geological Investigations of the North Pacific: Geol. Soc. Rev. Mem., 126:185-218.

Heezen, B. C., MacGregor, I. D., Foreman, H. P., et al., 1973. Diachronous deposits: a kinematic interpretation of the post Jurassic sedimentary sequence of the Pacific plate. Nature, 241:25-32.

Lancelot, Y., and Larson, R. L., 1975. Sedimentary and tectonic evolution of the northwestern Pacific. In Larson, R. L., Moberly, R., et al., Init. Repts. DSDP, 32: Washington (U.S. Govt. Printing Office), 925-939.

Larson, R. L., Moberly, R., et al., 1975. Init. Repts. DSDP, 32: Washington (U.S. Govt. Printing Office).

Nigrini, C. A., 1971. Radiolarian zones in the Quaternary of the equatorial Pacific Ocean. In Funnell, B. M., and Riedel, W. R. (Eds.), The Micropaleontology of Oceans: Cambridge (Cambridge Univ. Press), pp. 443-461.

Sclater, J. G., Anderson, R. N., and Bell, M. L., 1971. Elevation of ridges and evolution of the central eastern Pacific. J. Geophys. Res., 76:7888-7915.

Thiede, Jörn, 1979. History of the North Atlantic Ocean: evolution of an asymmetric zonal paleoenvironment in a latitudinal ocean basin. In Talwani, M. (Ed.), Deep Drilling Results in the Atlantic Ocean: Continental Margins and Paleoenvironment: Washington (Am. Geophys. Union), pp. 275-296.

Thierstein, H. R., 1979. Paleoceanographic implications of organic carbon and carbonate distribution in Mesozoic deep sea sediments. In Talwani, M. (Ed.), Deep Drilling Results in the Atlantic Ocean. Continental Margins and Paleoenvironment: Washington (Am. Geophys. Union), pp. 249-274.

van Andel, Tj. H., 1974. Cenozoic migration of the Pacific plate, northward shift of the axis of deposition, and paleobathymetry of the central equatorial Pacific. Geology, 2:507-510.

van Hinte, J. E., 1976. A Cretaceous time scale. Bull. Am. Assoc. Petrol. Geol., 60:498-516.

Winterer, E. L., 1973. Sedimentary facies and plate tectonics of equatorial Pacific. Bull. Am. Assoc. Petrol. Geol., 57:265-282. 
APPENDIX A

Major Components in Smear Slides of Sediment from Hole 464

SITE 464
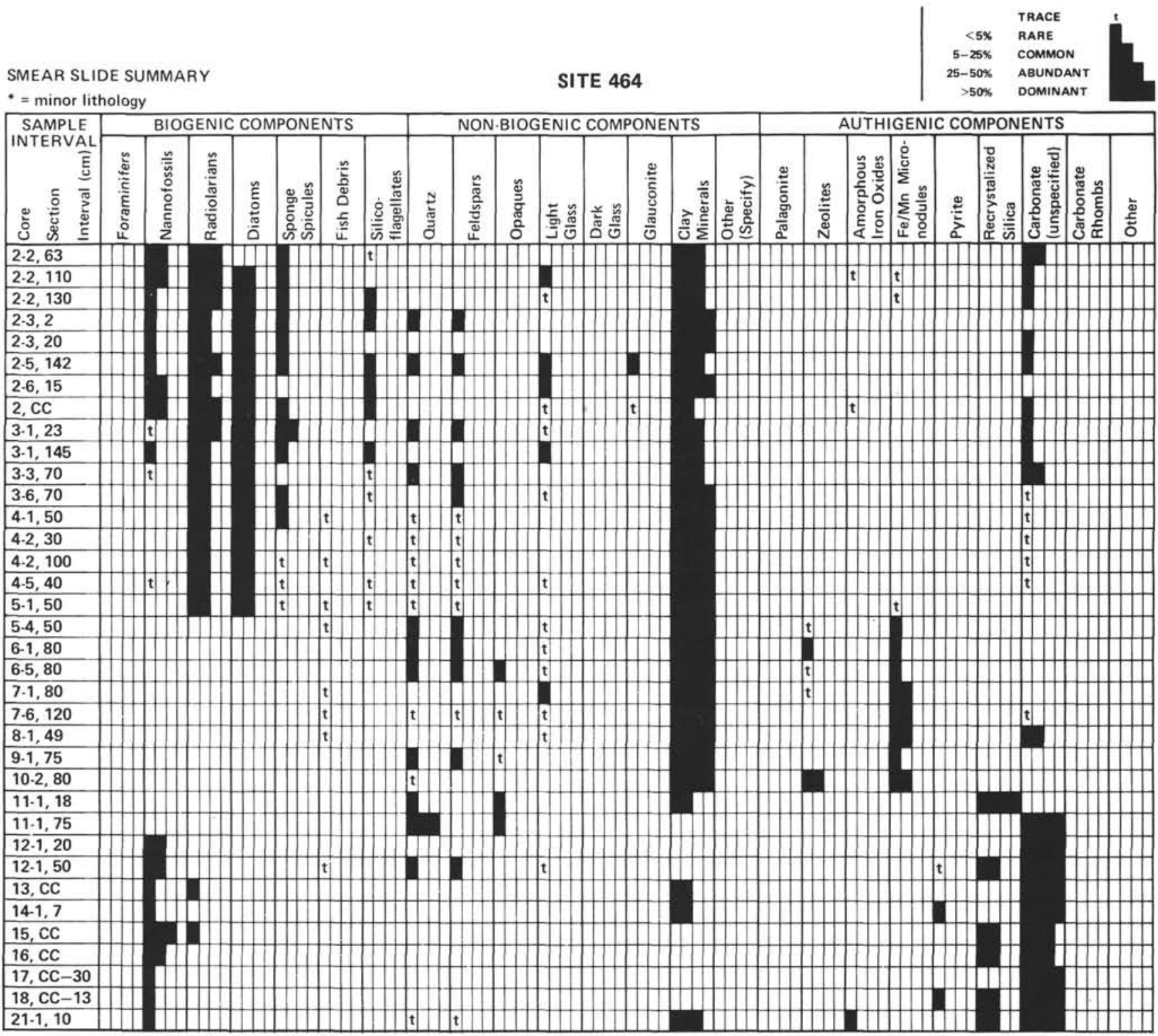

APPENDIX B

X-ray Diffraction Results for Bulk and Clay-Size Fractions of the Sediment from Site $\mathbf{4 6 4}$

\begin{tabular}{|c|c|c|c|c|c|c|c|c|c|c|c|c|c|c|c|c|c|}
\hline \multirow[b]{2}{*}{ Core } & \multirow[b]{2}{*}{ Section } & \multirow[b]{2}{*}{$\begin{array}{c}\text { Interval } \\
(\mathrm{cm})\end{array}$} & \multirow[b]{2}{*}{ Sample } & \multirow{2}{*}{$\begin{array}{l}\text { Sub-bottom } \\
\text { Depth } \\
\text { (m) }\end{array}$} & \multicolumn{8}{|c|}{ Bulk Mineralogy $(\%)$} & \multicolumn{5}{|c|}{ Clay Mineralogy $(\%)$} \\
\hline & & & & & $\begin{array}{l}\text { Clay Minerals } \\
+ \text { Volcanic Glass }\end{array}$ & Quartz & Feldspar & Carbonates & Opal-CT & Pyrite & Clinoptilolite & Others & Smectite & Illite & Chlorite & Kaolinite & Others \\
\hline 2 & 3 & $91-93$ & 1 & 7.42 & 69.4 & 10.4 & 2.0 & 19.2 & - & - & - & - & 11.1 & 67.4 & 15.0 & 6.5 & - \\
\hline 3 & 3 & $20-22$ & 2 & 16.21 & 66.2 & 7.2 & 1 & 25.6 & - & - & - & - & 12.4 & 72.4 & 4.2 & 11 & - \\
\hline 4 & 3 & $85-87$ & 3 & 26.36 & 84.4 & 13.0 & 2.6 & tr. & - & - & - & - & 9.0 & 70.0 & 10.5 & 10.5 & - \\
\hline 5 & 3 & $80-82$ & 4 & 35.81 & 87.6 & 10.4 & 2.0 & - & - & - & - & - & 8.9 & 68.8 & 12.7 & 9.6 & - \\
\hline 6 & 5 & $94-96$ & 5 & 48.45 & 91.2 & 3.9 & 4.6 & - & - & - & - & - & 89.0 & 5.5 & & 5.5 & - \\
\hline 7 & 5 & $83-85$ & 6 & 57.84 & 93.4 & 2.6 & 4.0 & - & - & - & - & - & 88 & - & 12 & & - \\
\hline 9 & 1 & $75-77$ & 7 & 70.76 & 98.0 & 2.0 & - & - & - & - & - & - & 13 & 67 & 20 & & - \\
\hline 10 & 3 & $70-72$ & 8 & 83.21 & 40.0 & 45.0 & - & - & 15 & - & - & Goethite & - & - & - & - & - \\
\hline
\end{tabular}


APPENDIX C

Coarse Fraction (>62 $\mu \mathrm{m}$ ) Components, Hole 464.

\begin{tabular}{|c|c|c|c|c|c|c|c|c|c|c|c|c|c|c|c|c|c|c|c|c|c|c|c|}
\hline \multirow[b]{3}{*}{$\begin{array}{c}\text { Sample } \\
\text { (interval in } \mathrm{cm} \text { ) }\end{array}$} & \multirow{3}{*}{ 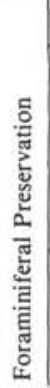 } & \multicolumn{21}{|c|}{ Coarse-Fraction Components } & \multirow{3}{*}{ 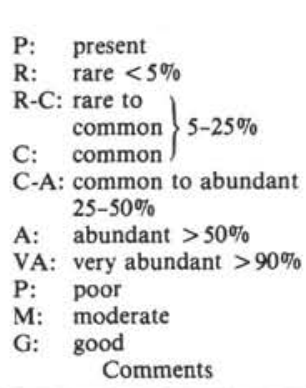 } \\
\hline & & \multicolumn{2}{|c|}{ 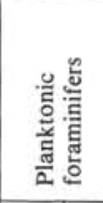 } & \multirow{2}{*}{ 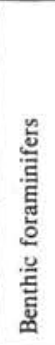 } & \multirow{2}{*}{ 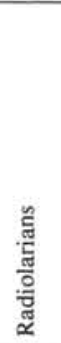 } & \multirow{2}{*}{ 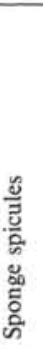 } & \multirow[b]{2}{*}{ 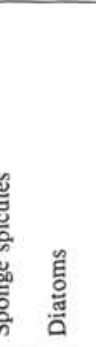 } & \multirow{2}{*}{ 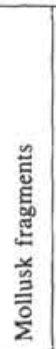 } & \multirow{2}{*}{ 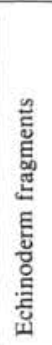 } & \multirow{2}{*}{ 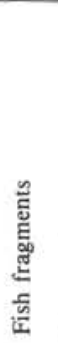 } & \multirow{2}{*}{ 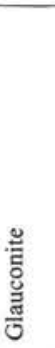 } & \multirow{2}{*}{ 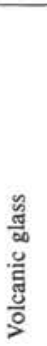 } & \multirow{2}{*}{ 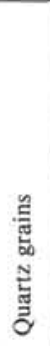 } & \multirow[b]{2}{*}{$\sum$} & \multirow{2}{*}{ 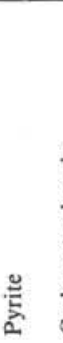 } & \multirow{2}{*}{ 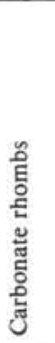 } & \multirow{2}{*}{ 厸 } & \multirow{2}{*}{ 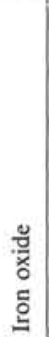 } & \multirow{2}{*}{ 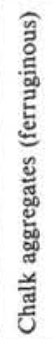 } & \multirow{2}{*}{\multicolumn{2}{|c|}{ 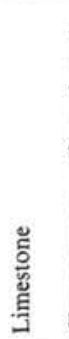 }} & \multirow{2}{*}{ 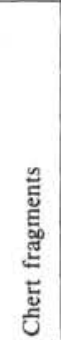 } & \\
\hline & & $\frac{0}{3}$ & 总 & & & & & & & & & & & & & & & & & & & & \\
\hline $\begin{array}{l}464-1-1,0-1 \\
2, \mathrm{CC} \\
4-1,118-122 \\
4, \mathrm{CC} \\
5, \mathrm{CC}\end{array}$ & & $\begin{array}{l}\mathrm{P} \\
\mathrm{P}\end{array}$ & & $\begin{array}{l}R \\
R \\
P\end{array}$ & $\begin{array}{l}\text { A } \\
\text { VA } \\
\text { VA } \\
\text { R }\end{array}$ & $\begin{array}{l}\mathrm{C} \\
\mathrm{C} \\
\mathrm{C} \\
\mathrm{R}\end{array}$ & $\begin{array}{l}\mathrm{C} \\
\mathrm{R}-\mathrm{C} \\
\mathrm{R}-\mathrm{C}\end{array}$ & & & $\begin{array}{l}\mathrm{P} \\
\mathrm{P} \\
\mathrm{R}\end{array}$ & & $\begin{array}{l}\mathrm{R} \\
\mathrm{C}\end{array}$ & $P$ & & & & $\begin{array}{l}\mathrm{P} \\
\mathrm{C}\end{array}$ & $\begin{array}{l}\mathrm{P} \\
\mathrm{C}\end{array}$ & & & & & \\
\hline $\begin{array}{l}6, \mathrm{CC} \\
7, \mathrm{CC} \\
8, \mathrm{CC} \\
9, \mathrm{CC} \\
10, \mathrm{CC}\end{array}$ & & & & $\begin{array}{l}\mathrm{C} * * \\
\mathrm{R} * * \\
\mathrm{R} * *\end{array}$ & $\mathrm{R}^{*}$ & & & & & $\begin{array}{l}C \\
C \\
R \\
R\end{array}$ & & $\begin{array}{l}\mathrm{A} \\
\mathrm{R}\end{array}$ & & & & & & $\begin{array}{l}\text { C } \\
\text { A } \\
\text { C } \\
\text { C }\end{array}$ & & & $\begin{array}{l}\text { A } \\
\text { A } \\
\text { A } \\
\text { C } \\
\text { A }\end{array}$ & A & \\
\hline $\begin{array}{l}13 \text { (water) } \\
17 \text { (water) } \\
20-1 \\
21-1,3-4 \\
21 \text { (water) }\end{array}$ & & $\begin{array}{l}\mathrm{R} \\
\mathrm{R}\end{array}$ & & & $\begin{array}{l}\text { C } \\
\text { A } \\
\text { VA } \\
\text { C }\end{array}$ & C & & & & & & & $\mathrm{R}$ & & & & & & $\begin{array}{l}\text { A } \\
\text { A } \\
\text { C } \\
\text { A }\end{array}$ & & & $\begin{array}{l}\mathrm{R} \\
\mathrm{C} \\
\mathrm{A}\end{array}$ & $\begin{array}{l}\text { very small } \\
\text { amount of } \\
\text { coarse fraction }\end{array}$ \\
\hline $\begin{array}{l}23, \mathrm{CC} \\
27-1,25 \\
27 \text { (water) } \\
28-1,25 \\
29-1,20-22\end{array}$ & & $\begin{array}{l}\text { C-A } \\
\text { A } \\
\text { C }\end{array}$ & & & $\begin{array}{c}\text { VA } \\
\text { A }\end{array}$ & $\mathrm{R}$ & & & & & & & & & & & & & $\begin{array}{l}\mathrm{C} \\
\mathrm{C} \\
\mathrm{R}\end{array}$ & & & $\begin{array}{l}\text { C-A } \\
\text { A } \\
\text { R }\end{array}$ & \\
\hline $\begin{array}{l}29-1,90-91 \\
30 \text { (water) } \\
31 \text { (water) } \\
32-1,18 \\
33 \text { (water) }\end{array}$ & $P$ & $\begin{array}{l}\mathrm{R} \\
\mathrm{P} \\
\mathrm{P}\end{array}$ & & & $\begin{array}{l}\text { VA } \\
\text { A } \\
R \\
R\end{array}$ & & & & & & $\begin{array}{l}\mathrm{P} ? \\
\mathrm{R} ?\end{array}$ & & $\begin{array}{l}\mathrm{P} \\
\mathrm{R} \\
\mathrm{R} \\
\mathrm{R} \\
\mathrm{R}\end{array}$ & & & & & $\begin{array}{l}\mathrm{C} \\
\mathrm{R} \\
\mathrm{C}\end{array}$ & & & $\begin{array}{l}\mathrm{R} \\
\mathrm{C} \\
\mathrm{C}\end{array}$ & $\begin{array}{c}\mathrm{R} \\
\mathrm{C} \\
\mathrm{A} \\
\mathrm{VA} \\
\mathrm{C}\end{array}$ & \\
\hline
\end{tabular}

- Recrystallized.

** Arenaceous.

APPENDIX D

Grain-Size Analysis, Site 464

\begin{tabular}{lcccccccl}
\hline Hole & Core & Section & $\begin{array}{c}\text { Interval } \\
(\mathrm{cm})\end{array}$ & $\begin{array}{c}\text { Sub-bottom } \\
\text { Depth } \\
(\mathrm{m})\end{array}$ & $\begin{array}{c}\text { Sand } \\
(\%)\end{array}$ & $\begin{array}{c}\text { Silt } \\
(\%)\end{array}$ & $\begin{array}{c}\text { Clay } \\
(\%)\end{array}$ & Classification \\
\hline 464 & 2 & 2 & 101.0 & 6.01 & 2.2 & 33.8 & 64.0 & Silty clay \\
464 & 3 & 2 & 40.0 & 14.90 & 2.8 & 36.3 & 60.8 & Silty clay \\
464 & 3 & 4 & 40.0 & 17.90 & 1.9 & 35.6 & 62.5 & Silty clay \\
464 & 4 & 2 & 58.0 & 24.58 & 0.7 & 31.0 & 68.3 & Silty clay \\
464 & 4 & 4 & 60.0 & 27.60 & 1.0 & 33.2 & 65.8 & Silty clay \\
464 & 5 & 2 & 70.0 & 34.20 & 0.5 & 42.1 & 57.4 & Silty clay \\
464 & 5 & 4 & 70.0 & 37.20 & 0.1 & 23.1 & 76.8 & Clay \\
464 & 6 & 2 & 100.0 & 44.00 & 0.0 & 12.8 & 87.2 & Clay \\
464 & 7 & 5 & 72.0 & 57.72 & 0.1 & 49.7 & 50.1 & Silty clay \\
464 & 9 & 1 & 104.0 & 71.04 & 0.0 & 23.4 & 76.5 & Clay \\
464 & 10 & 2 & 136.0 & 82.36 & 7.5 & 15.7 & 76.9 & Clay \\
\hline
\end{tabular}



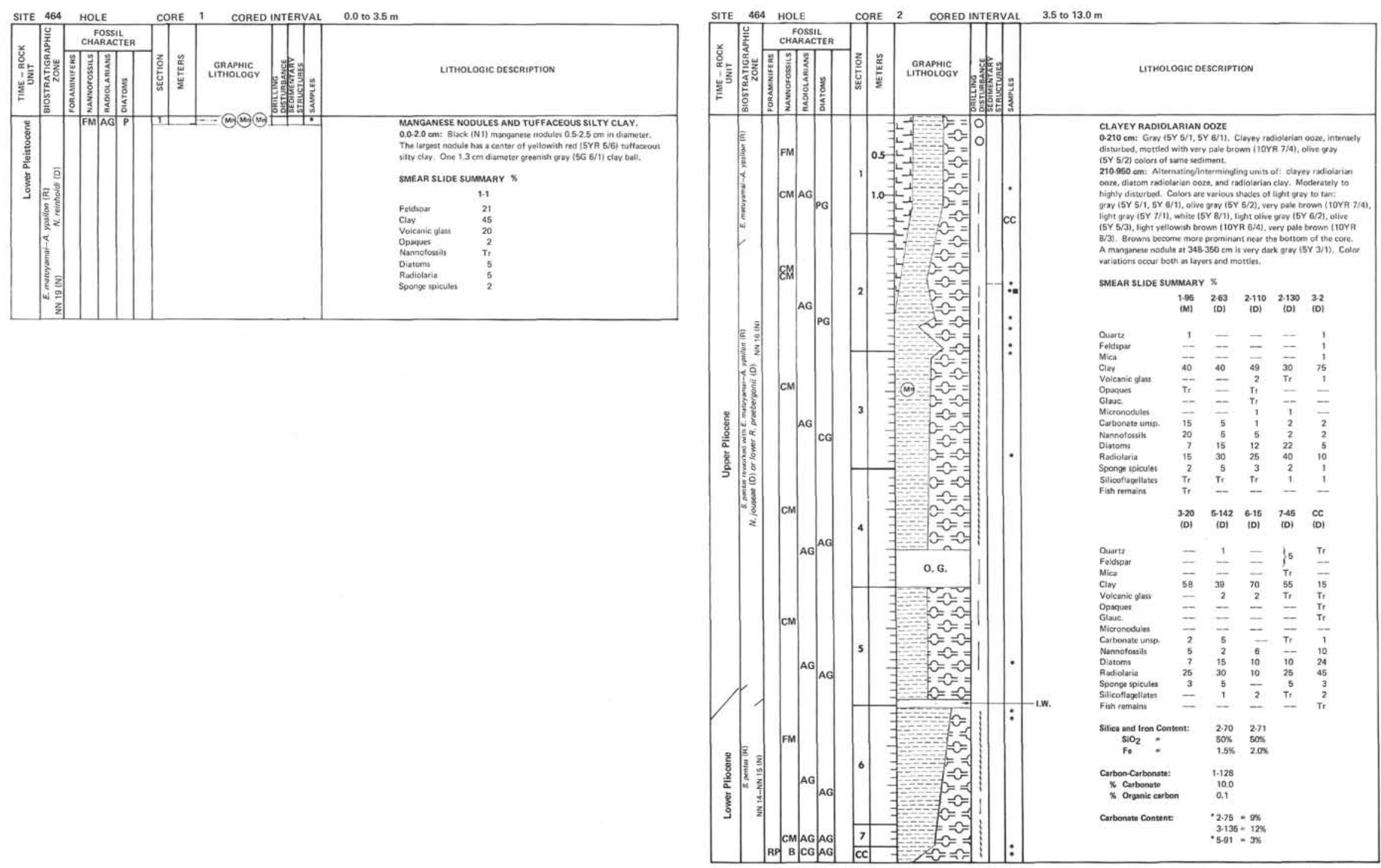

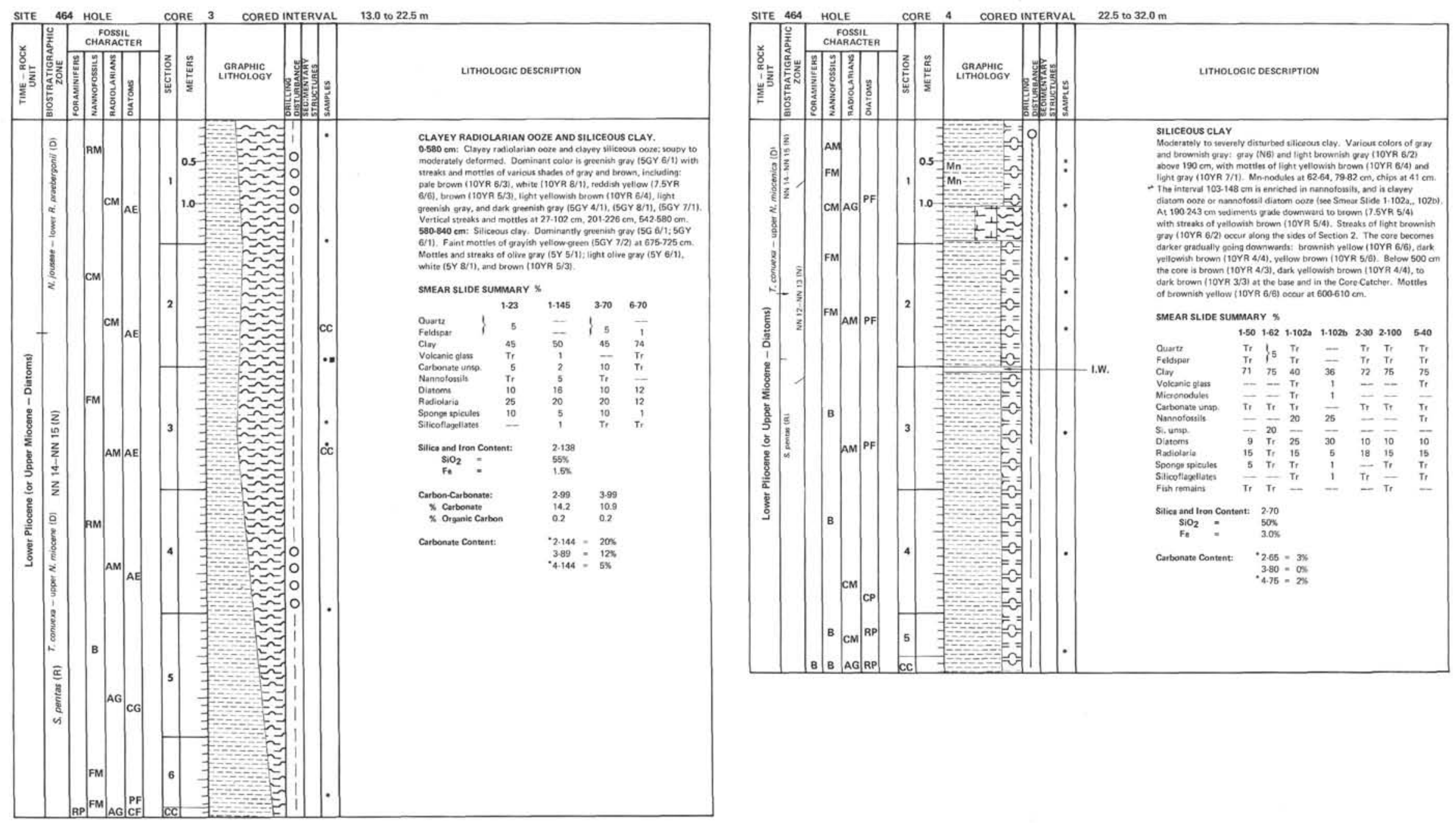

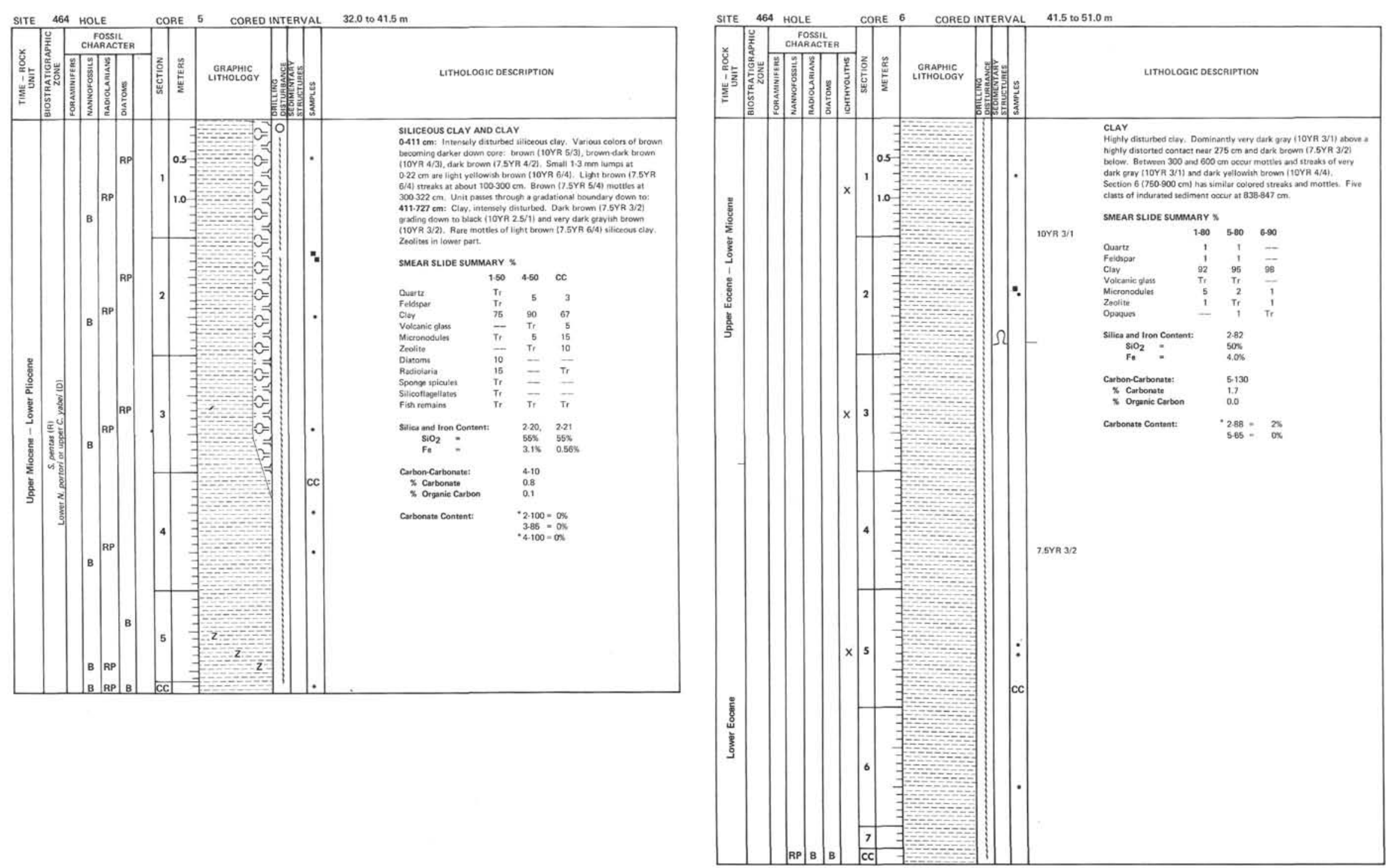

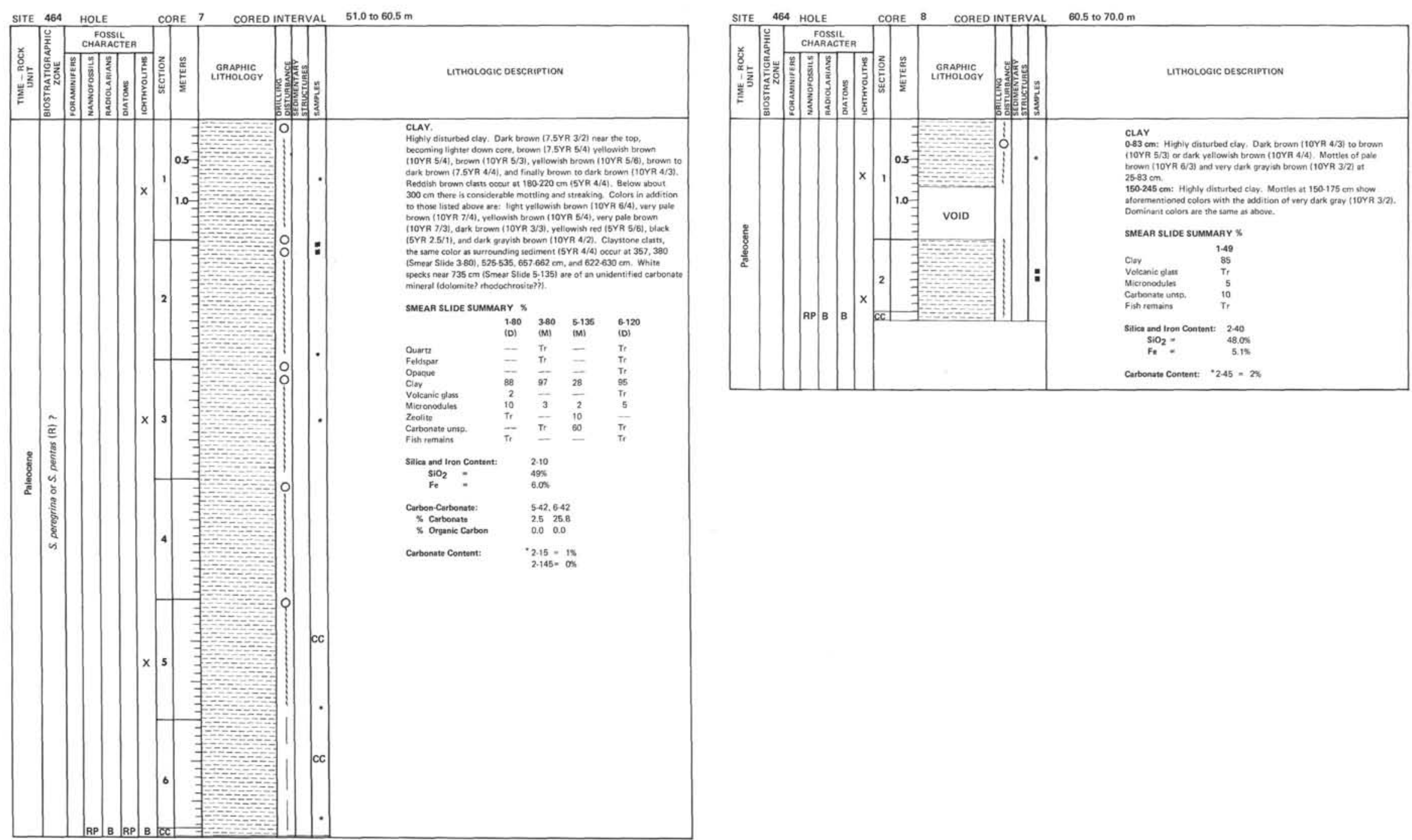

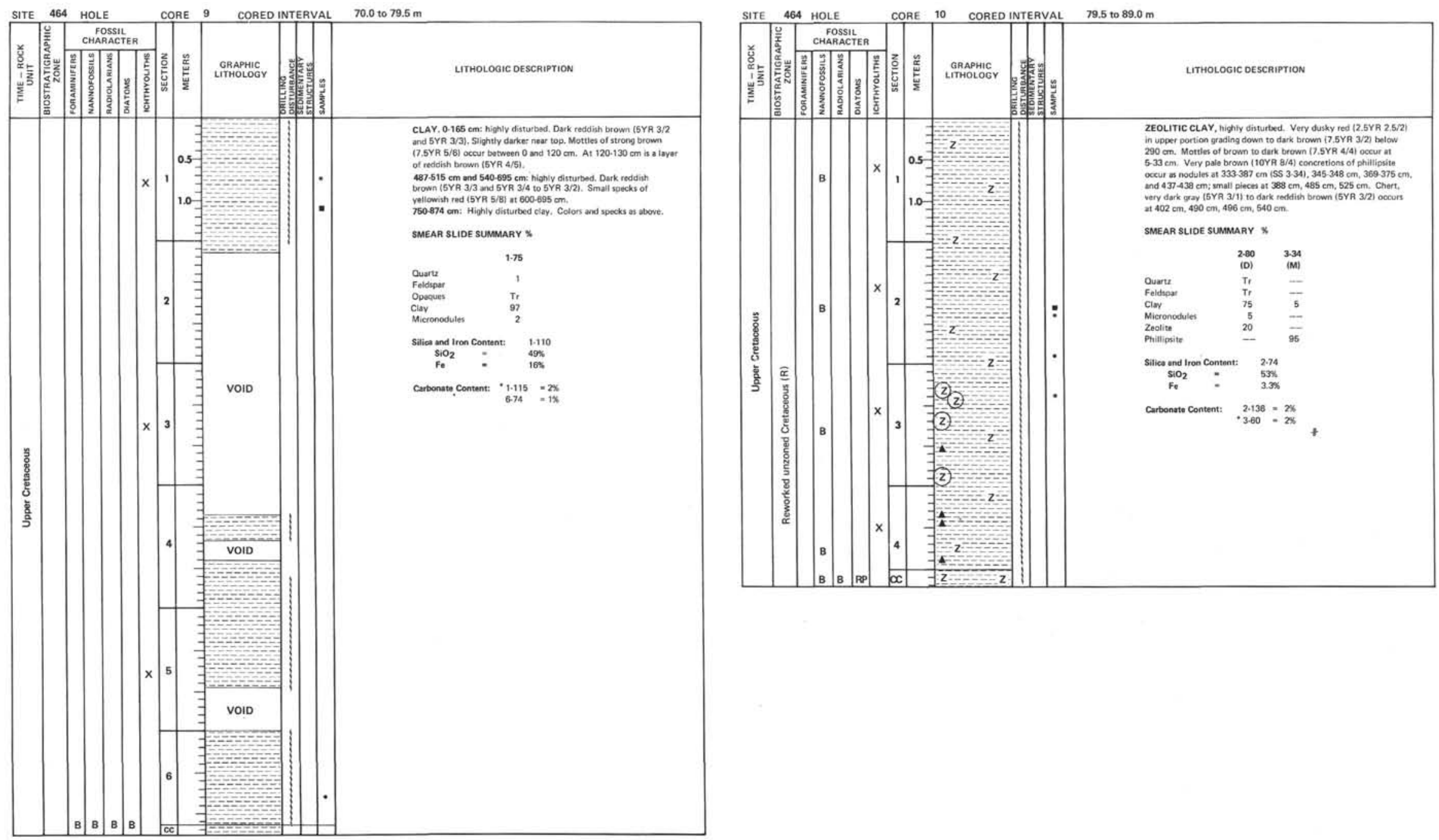

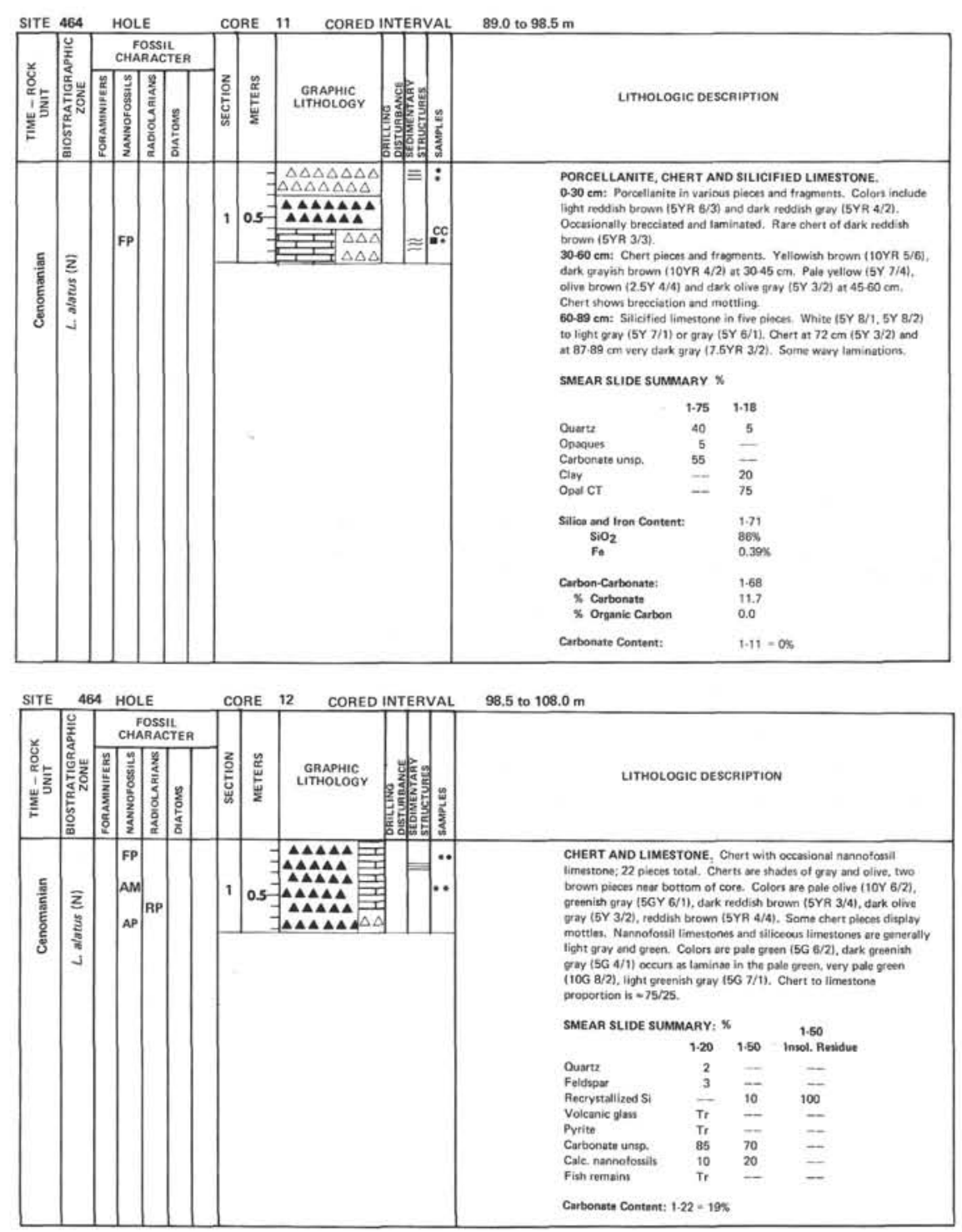
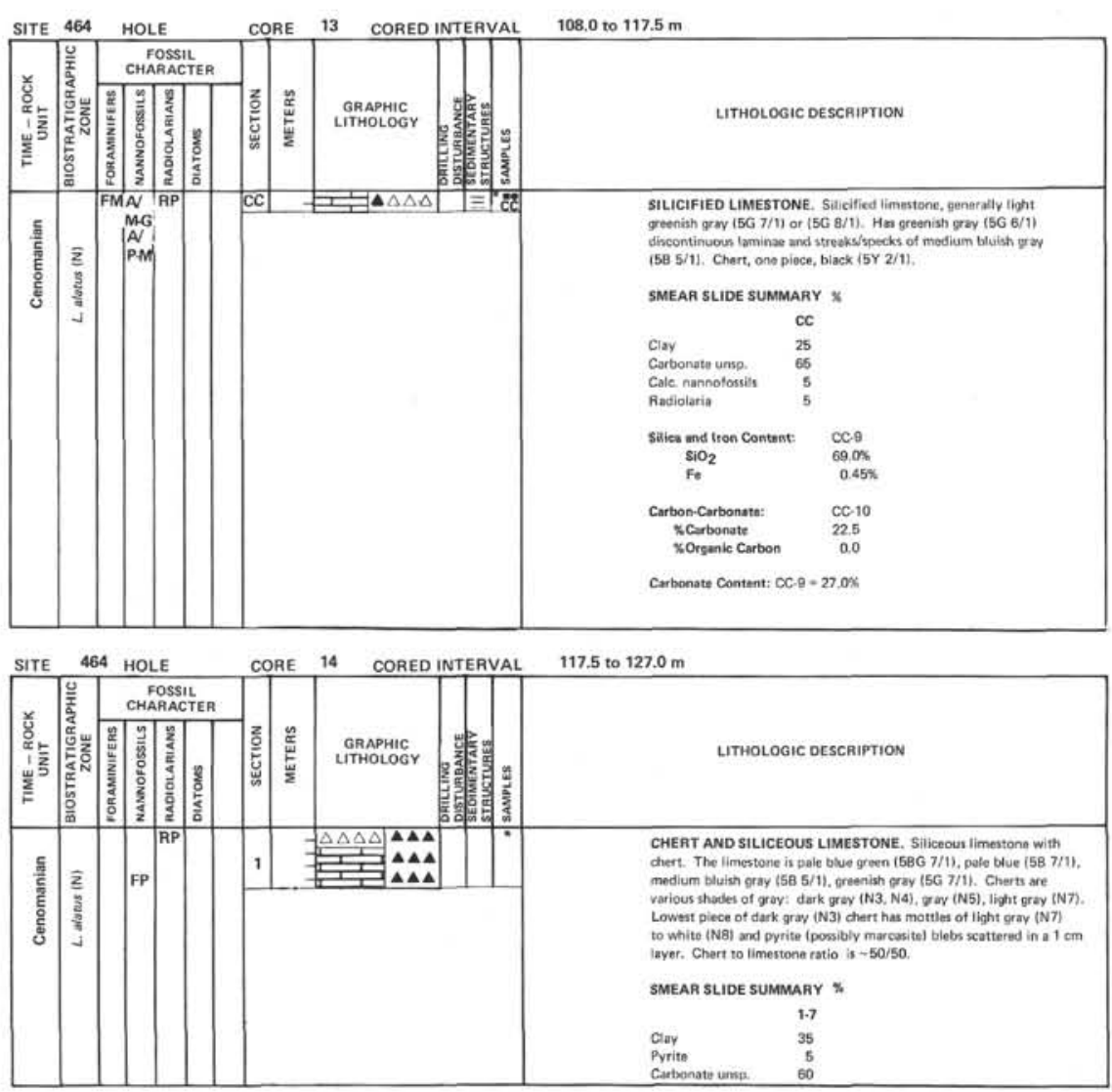

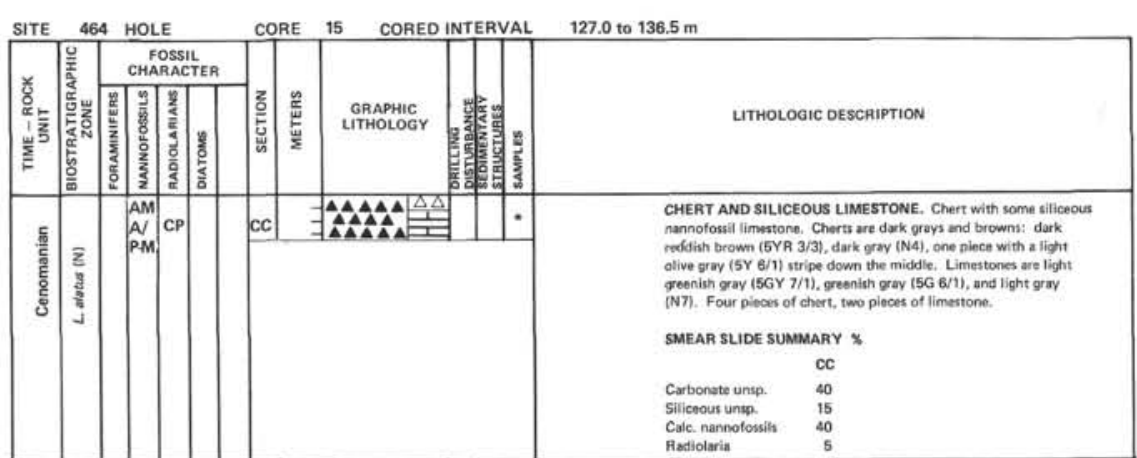



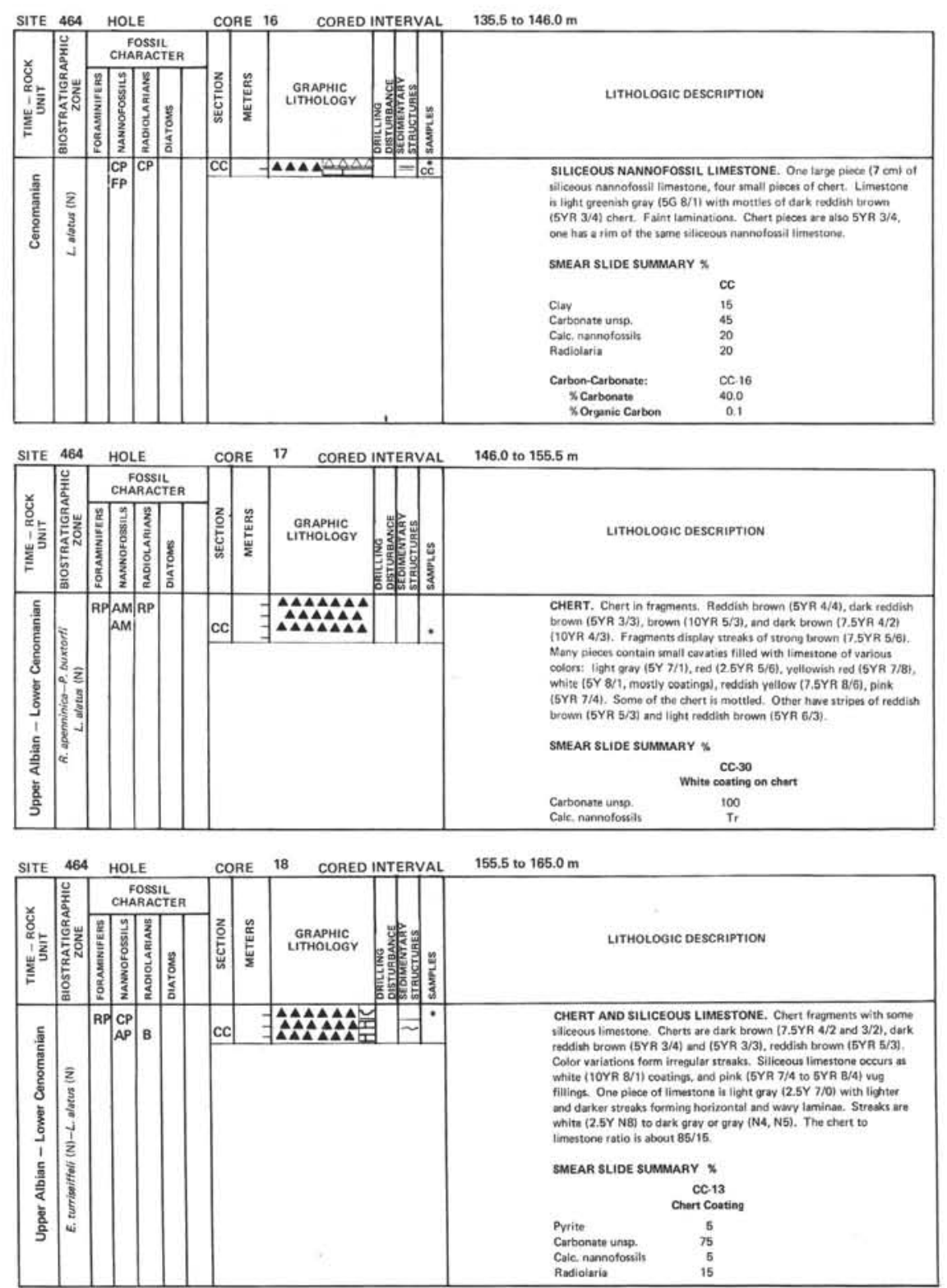
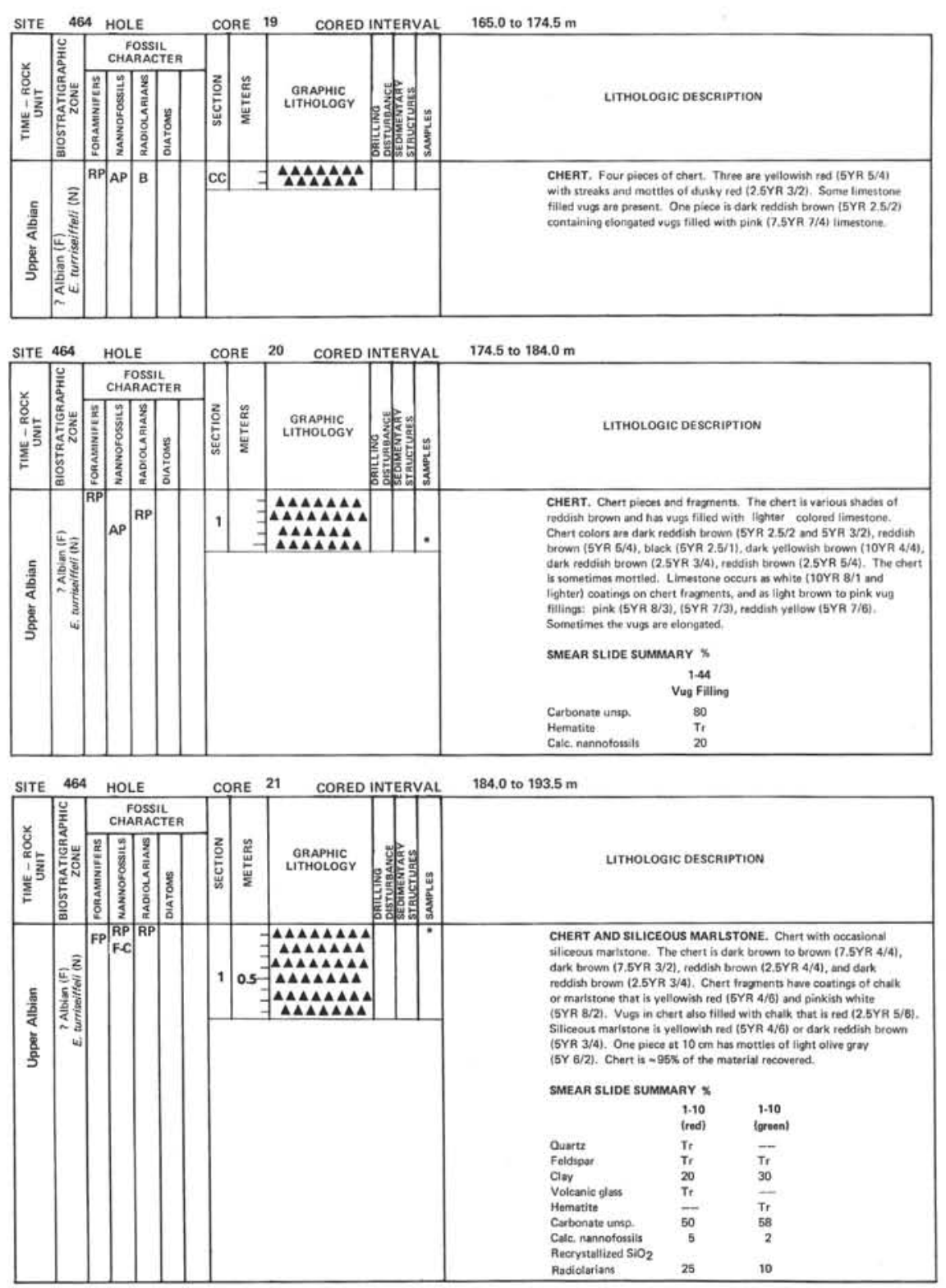

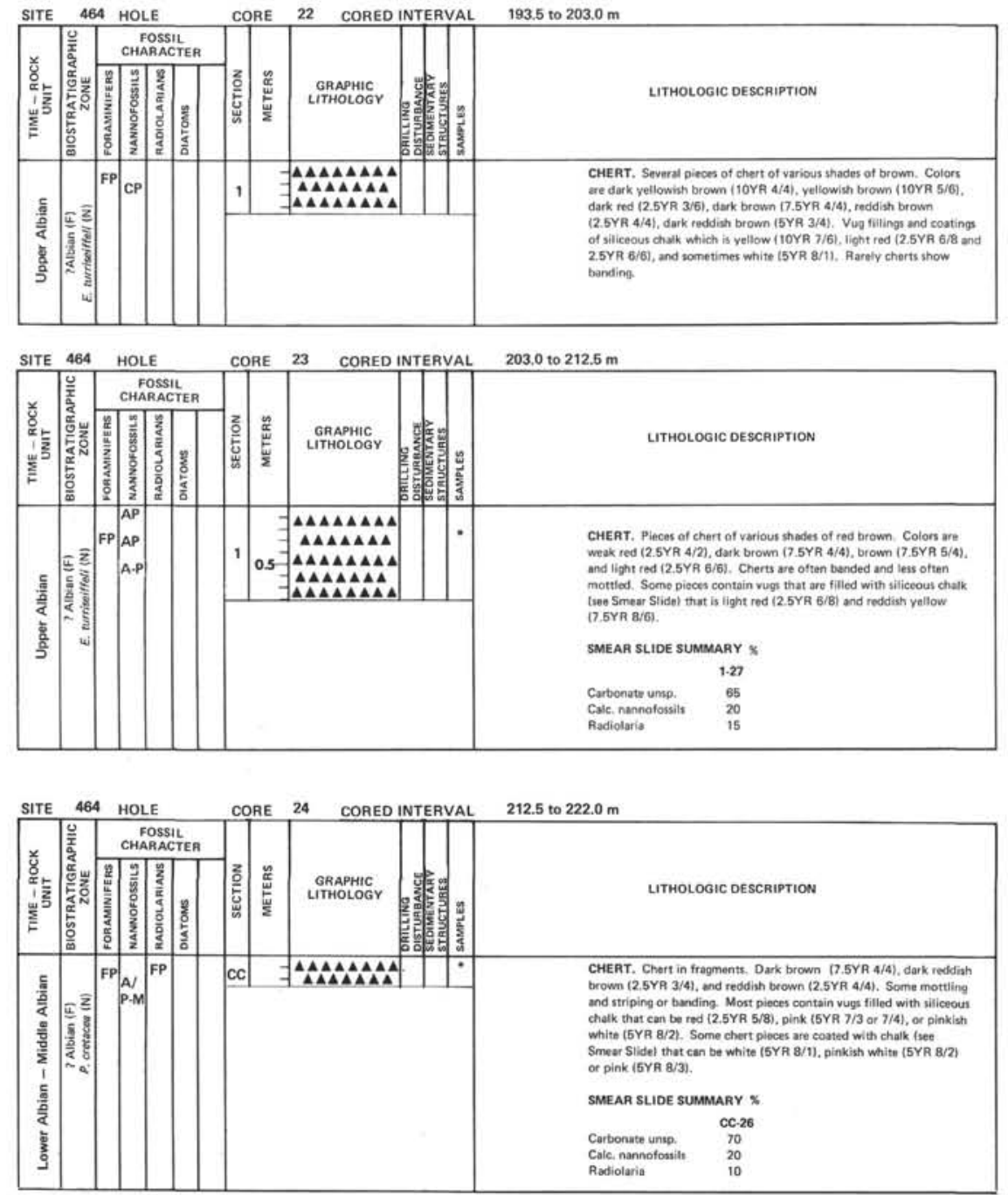
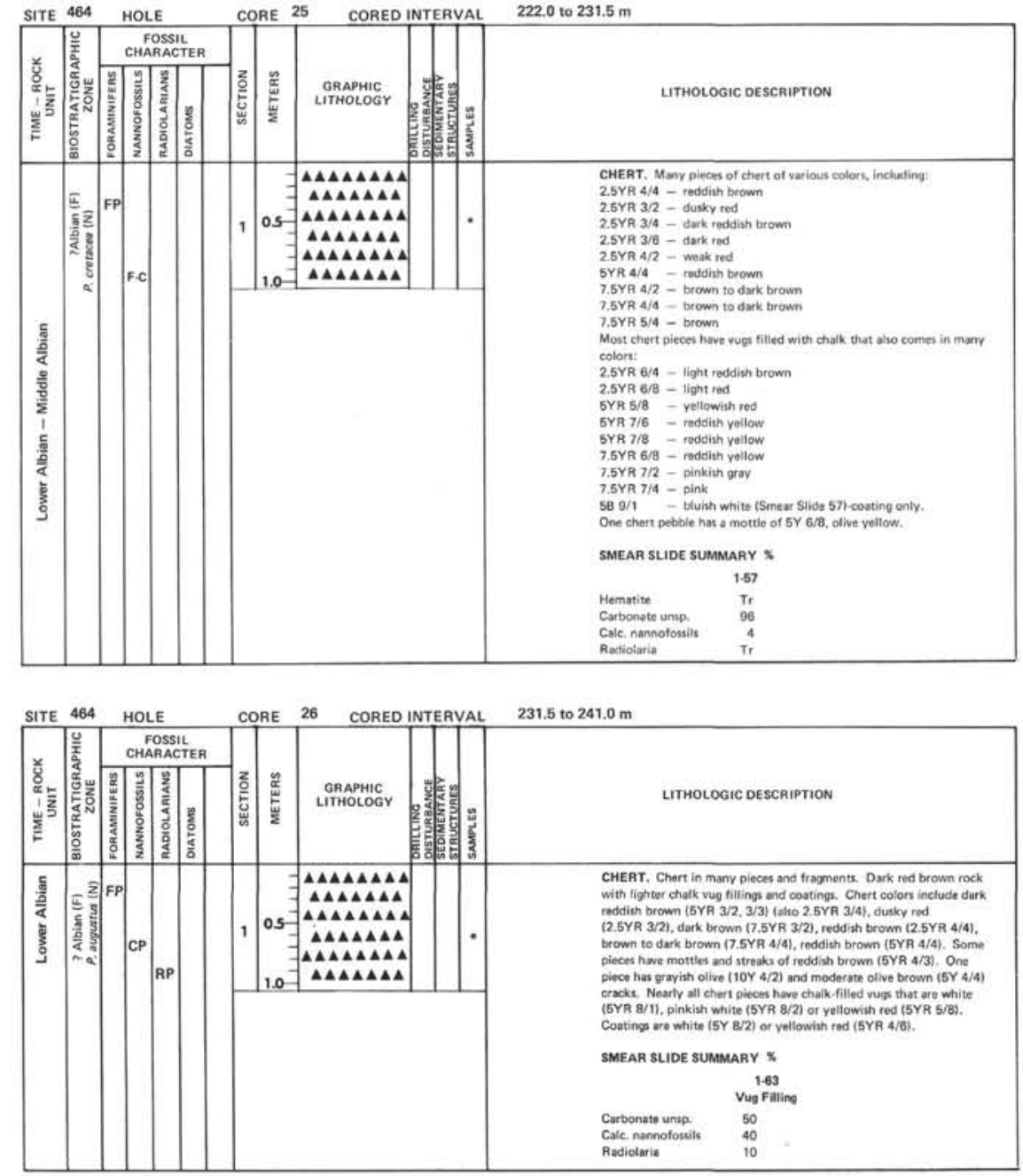

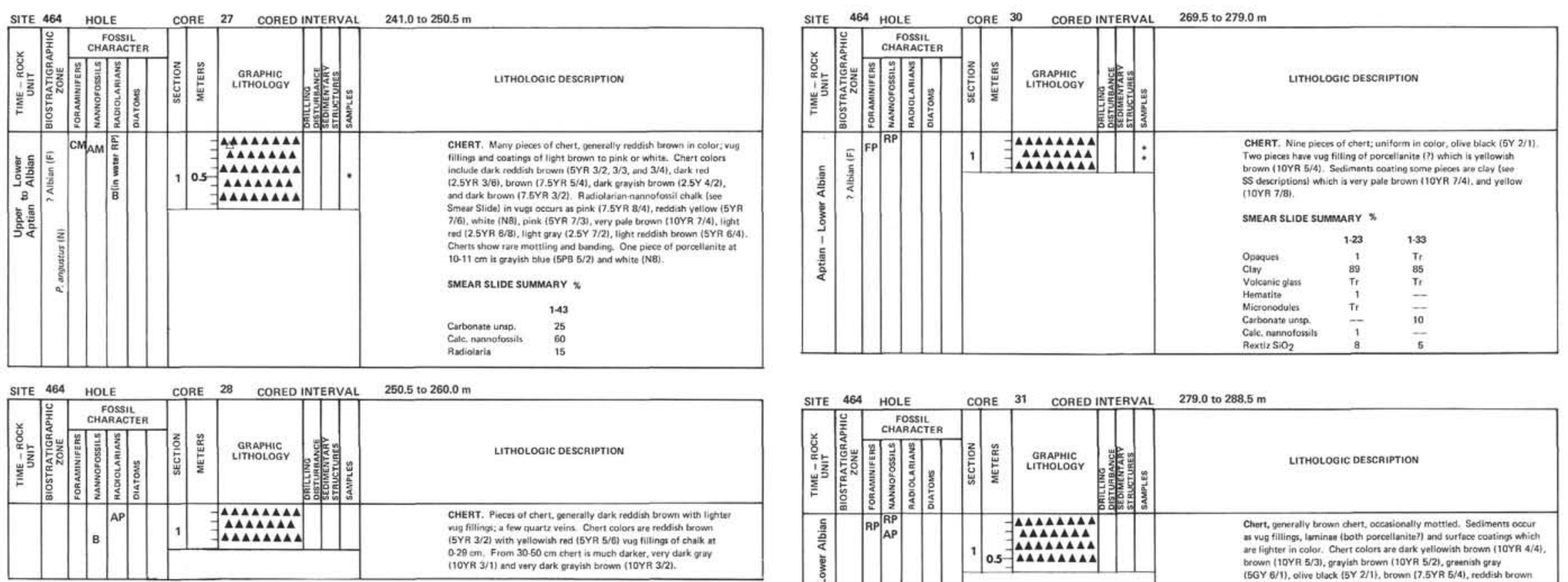

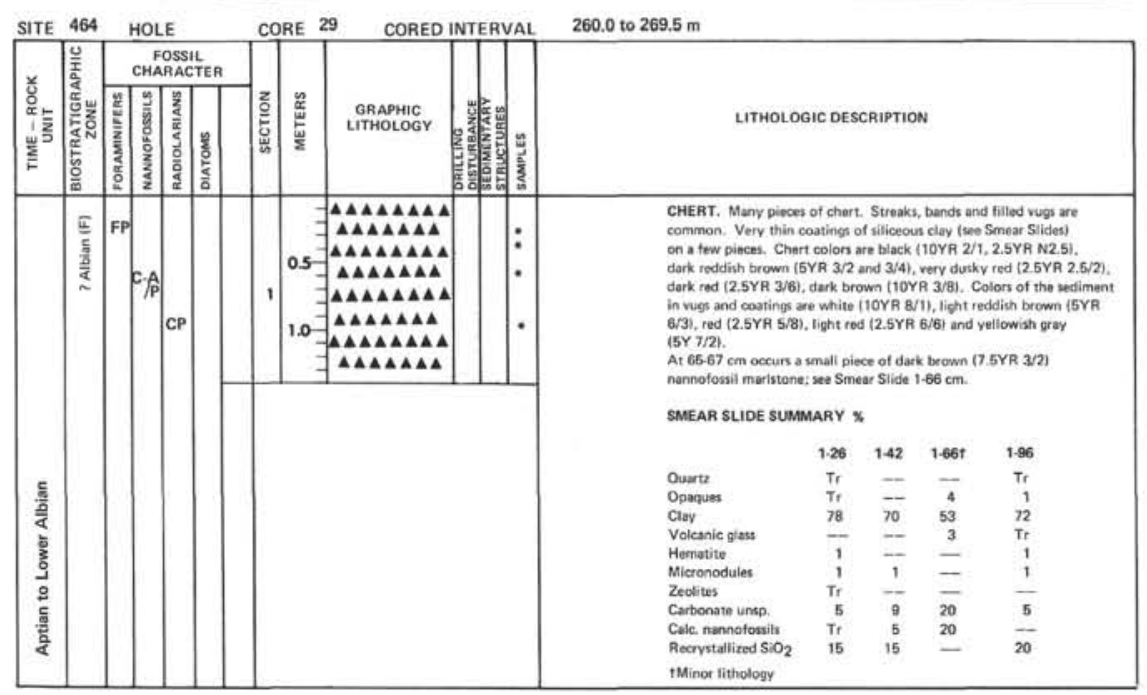

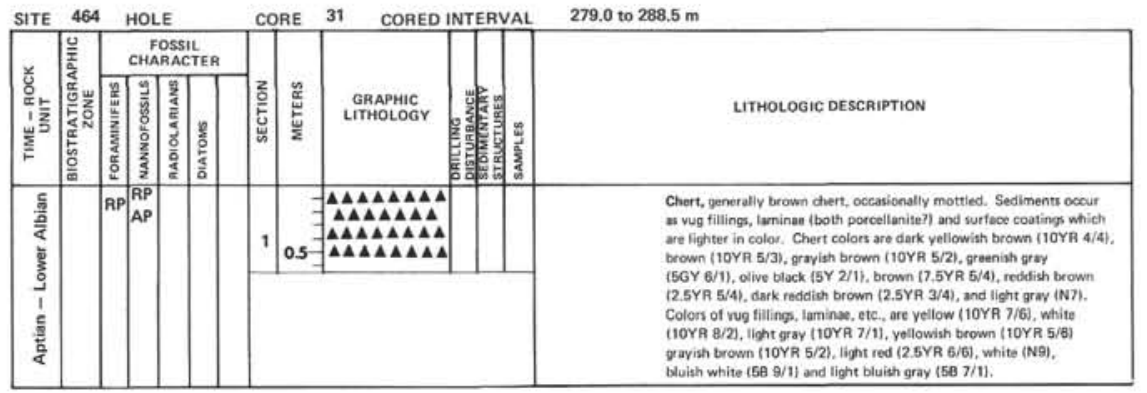

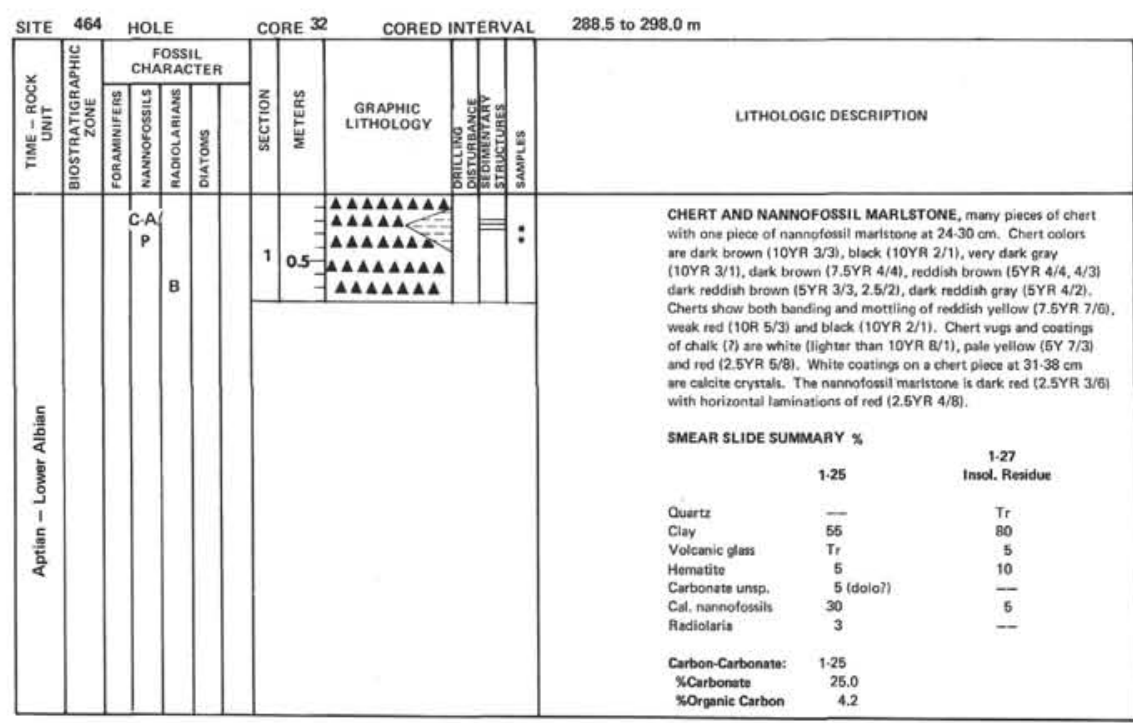




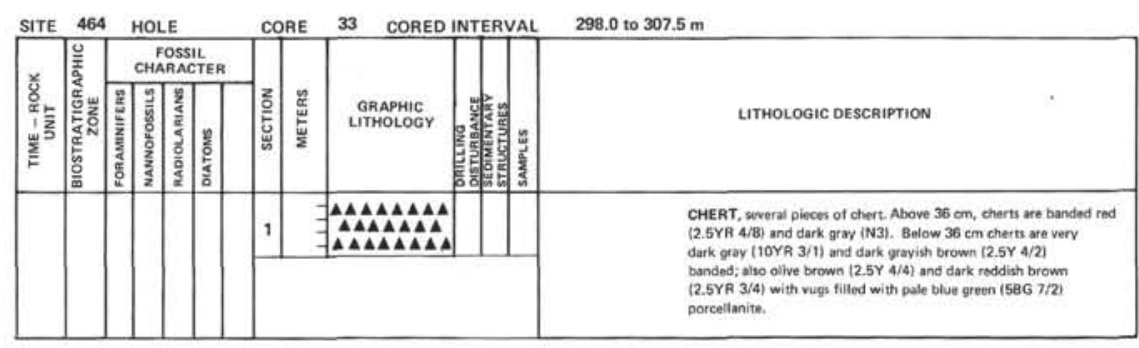

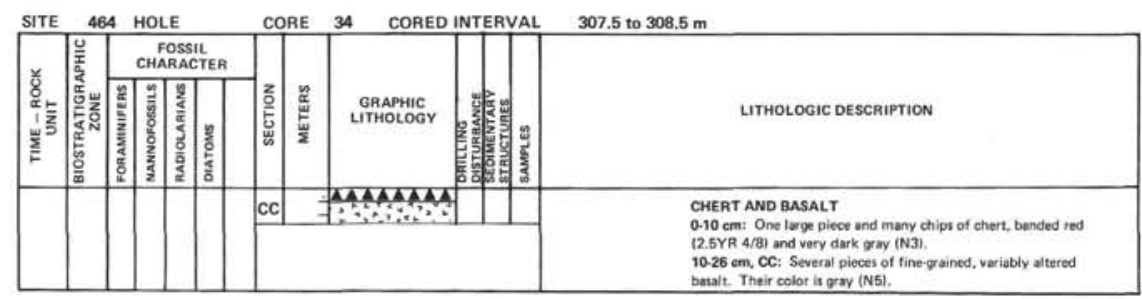


464-2 (464-1 NO DATA)

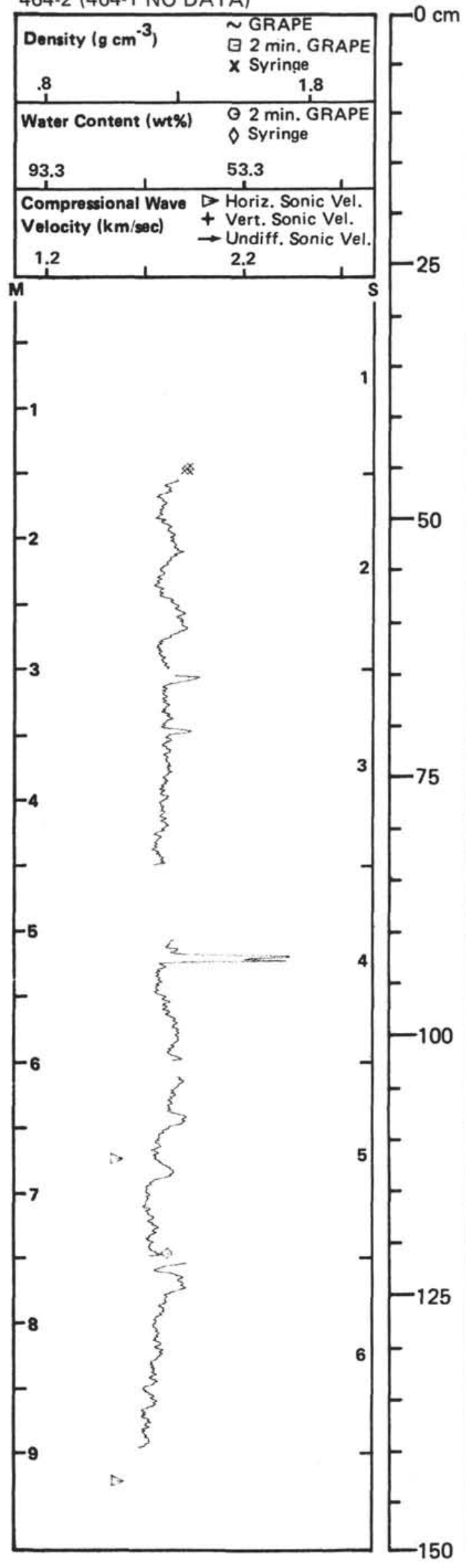

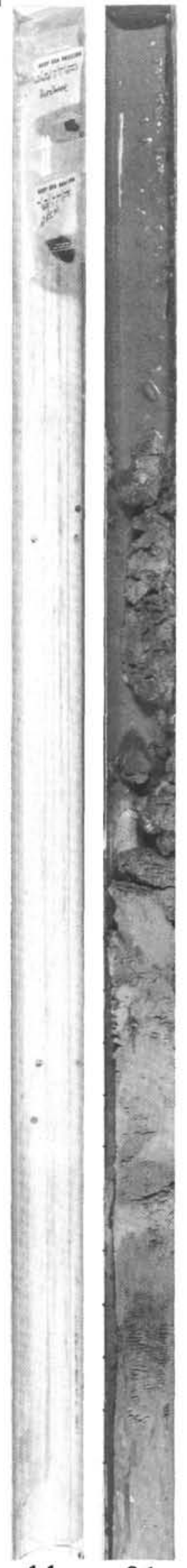

1-1
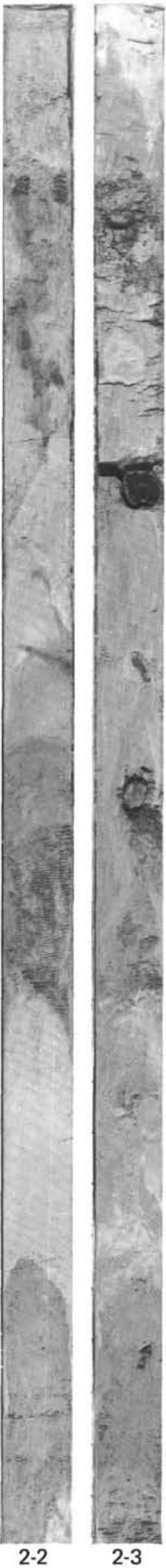
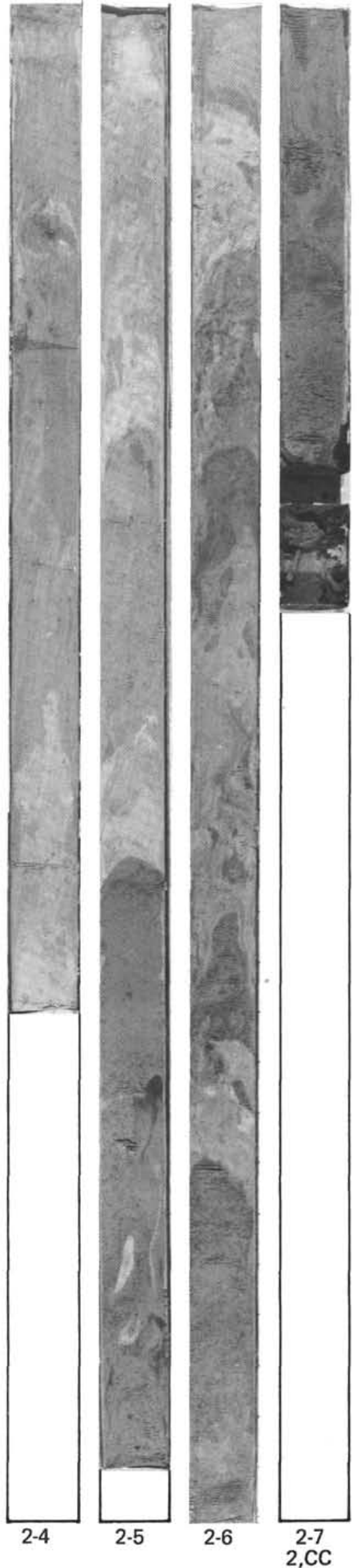
464-3

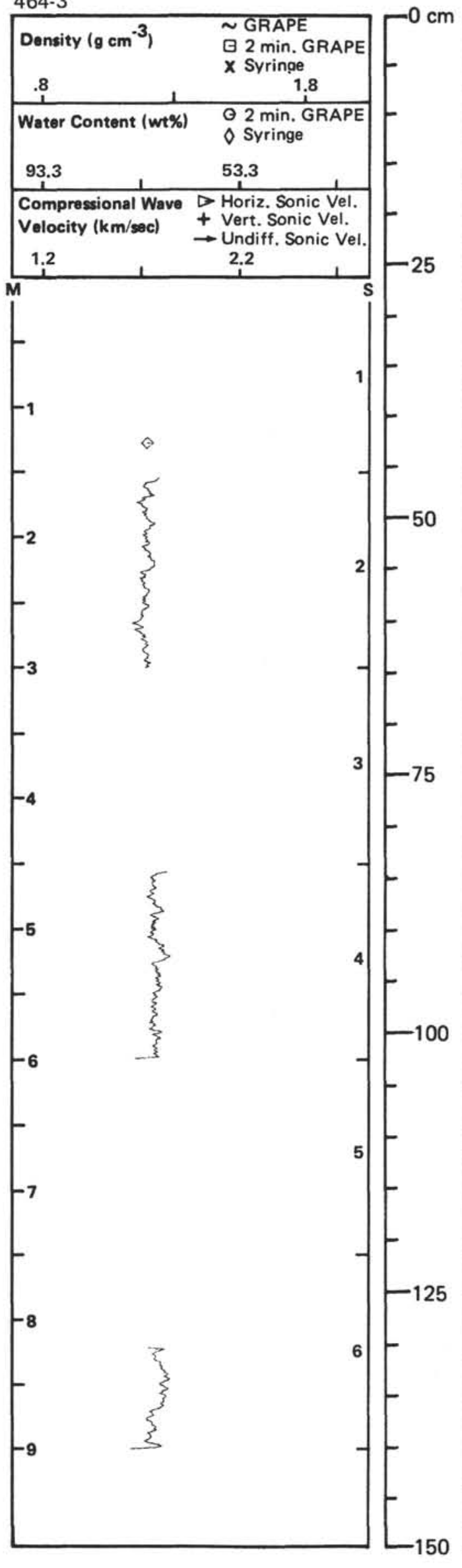

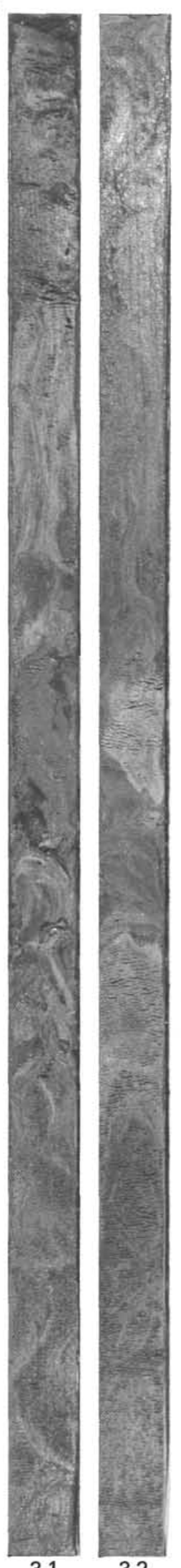

3-2
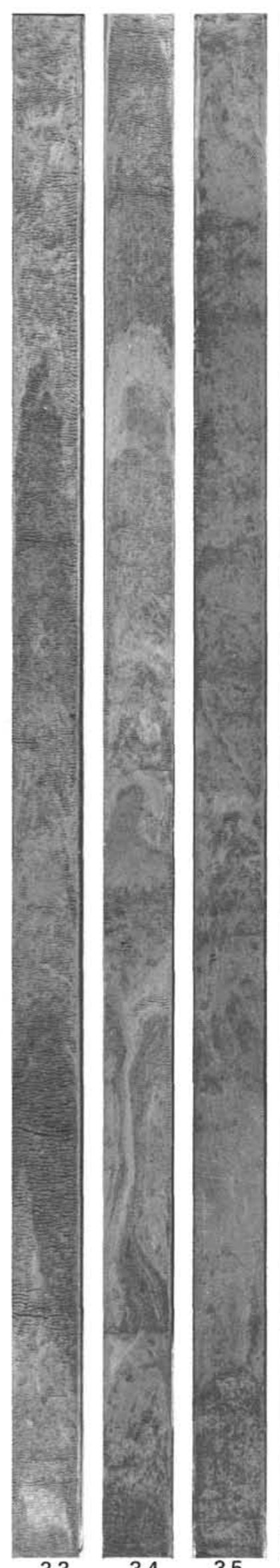

3-5

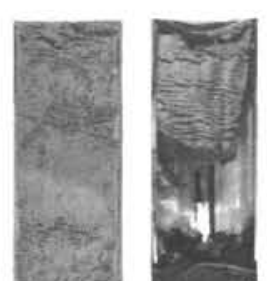




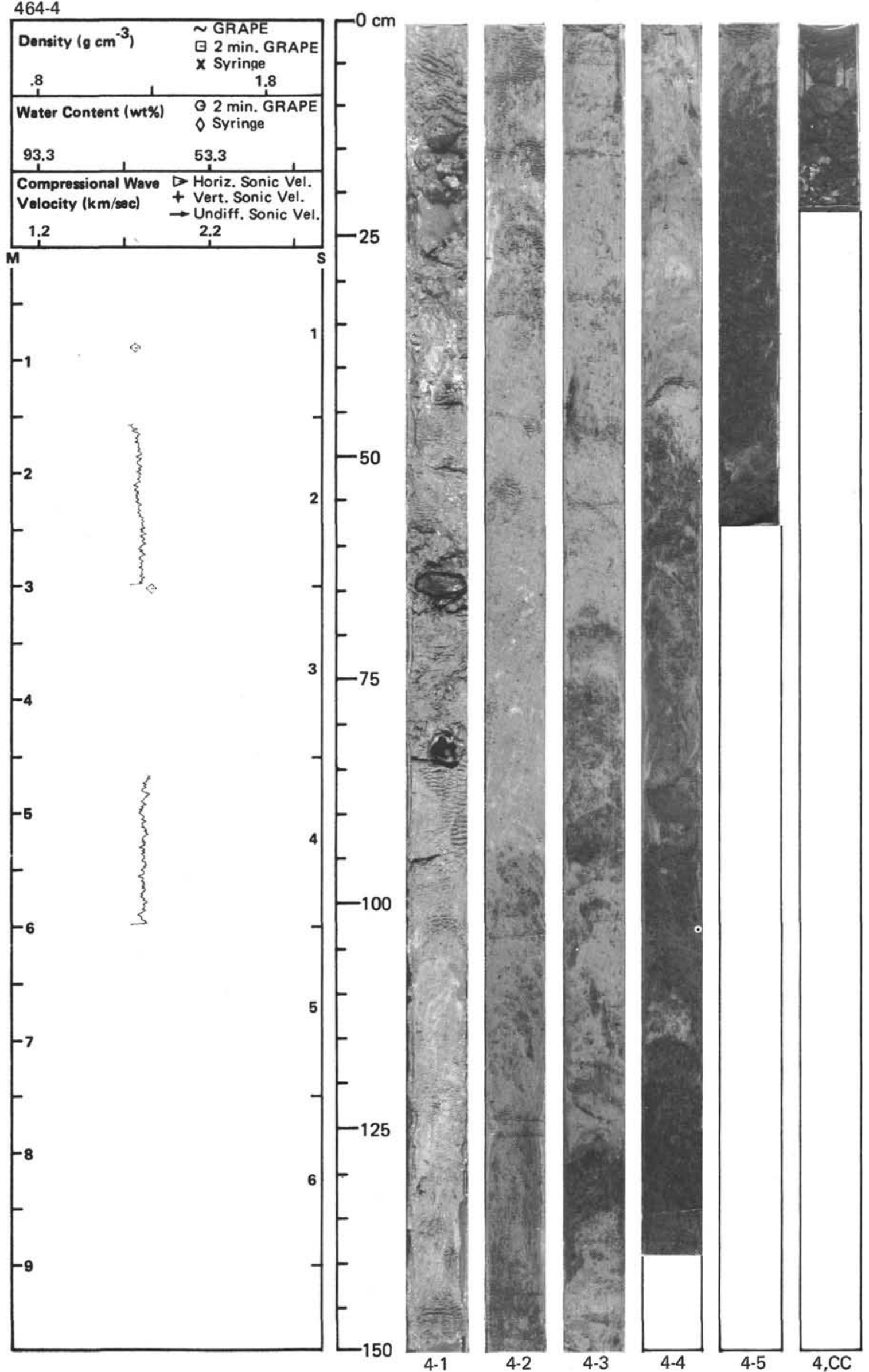


464-5

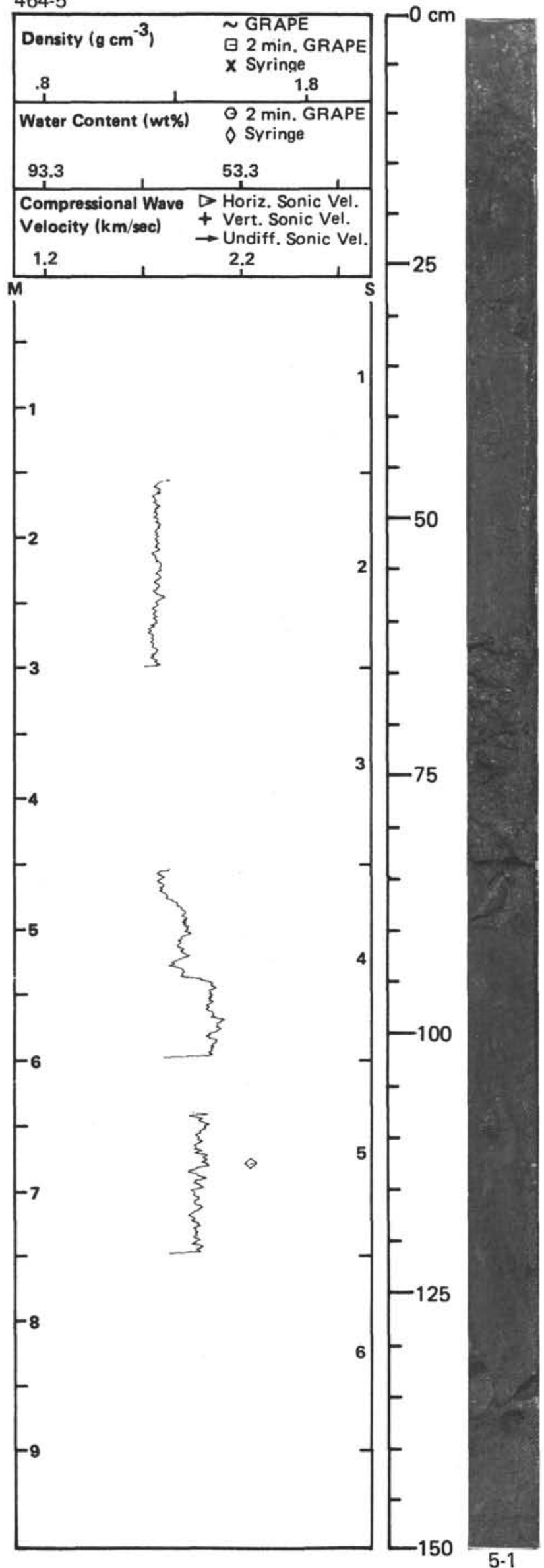

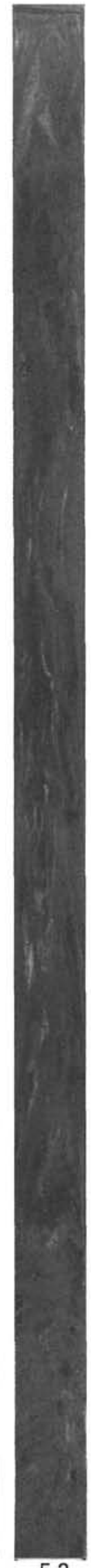

5-2

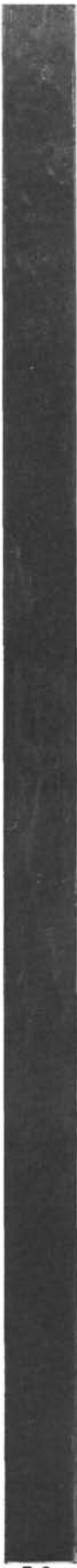

5-3

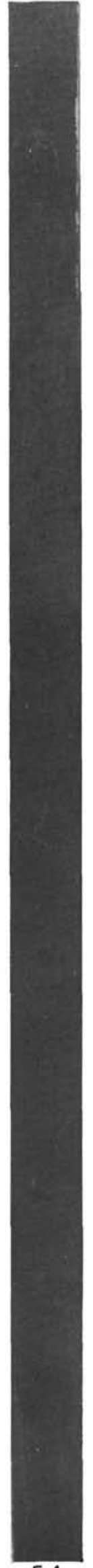

5-4

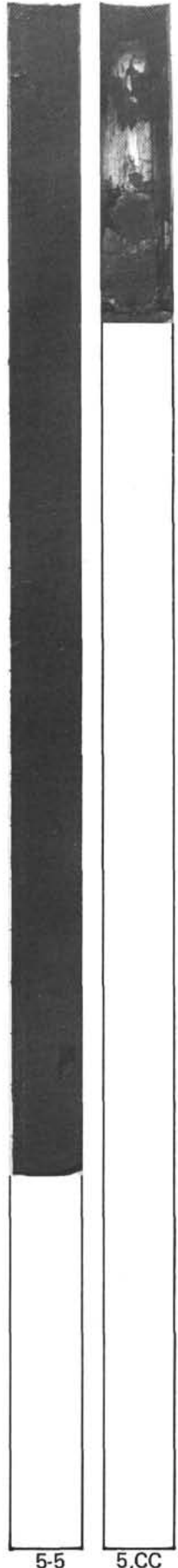




\section{4-6}
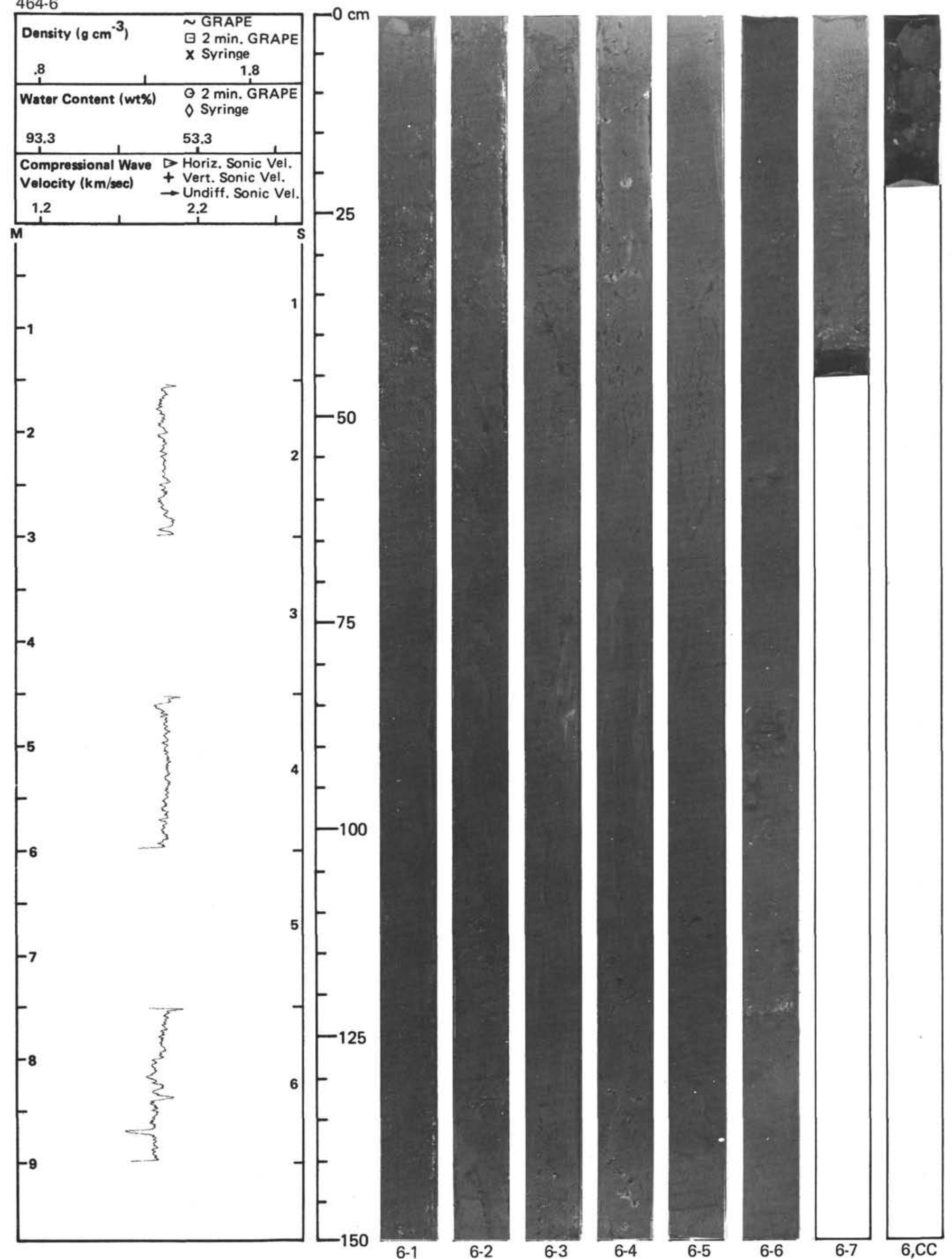


\section{4-7}

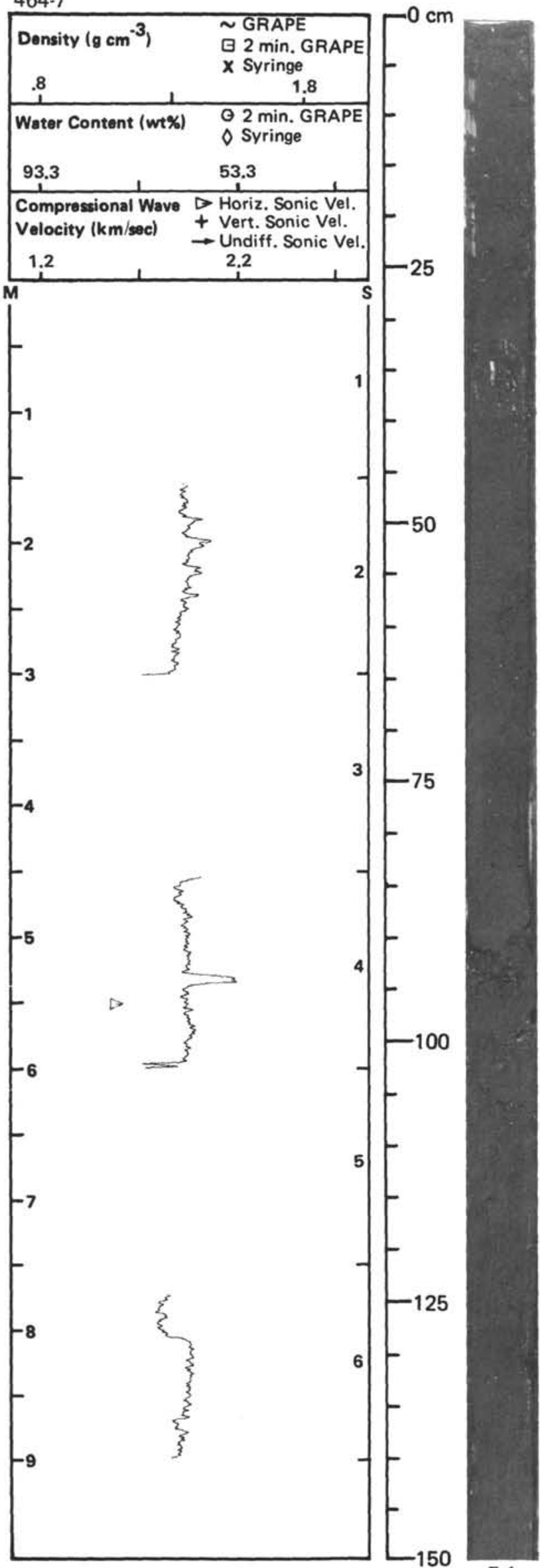

150

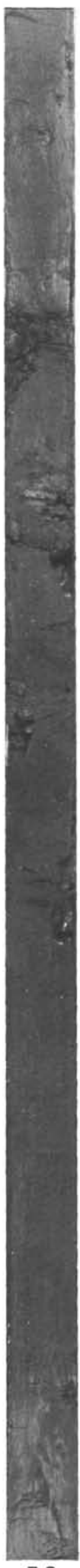

7-2

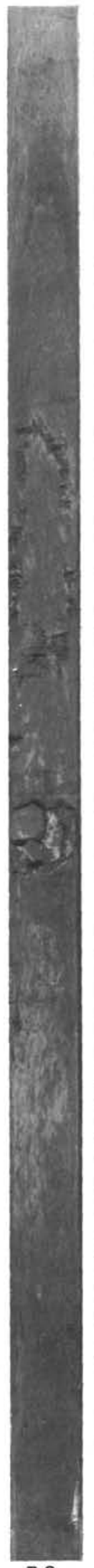

7-3
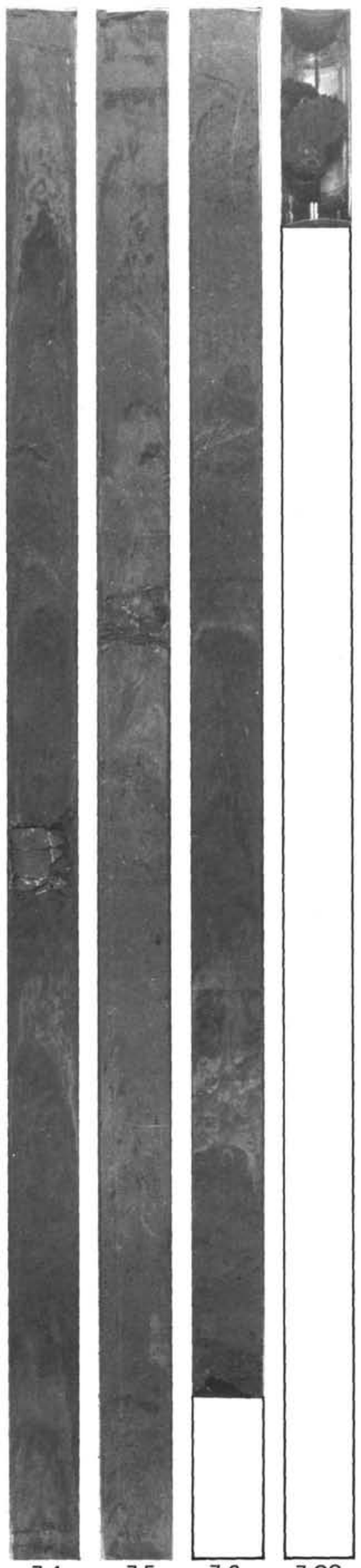
SITE 464

464-9 (464-8 NO DATA)

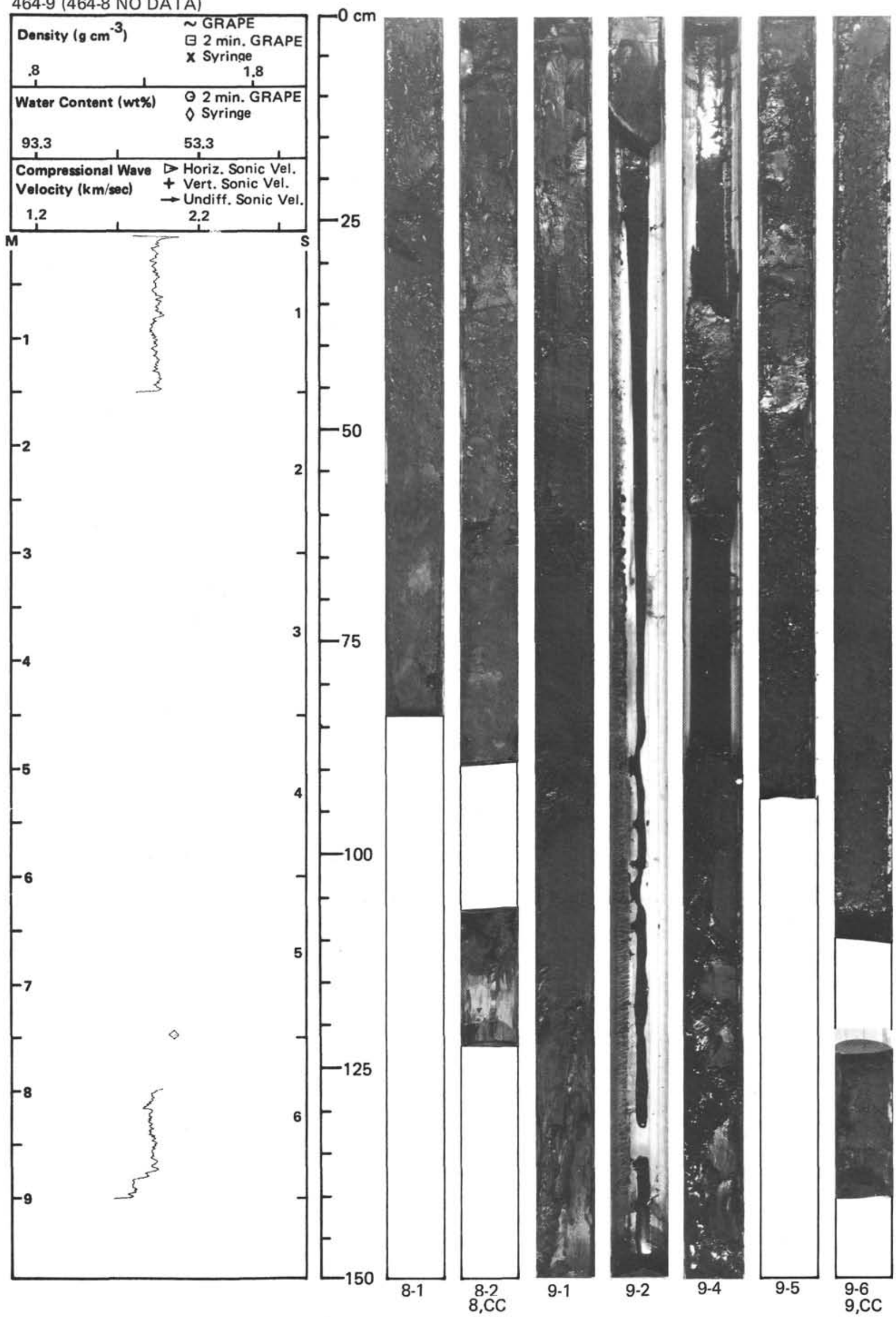




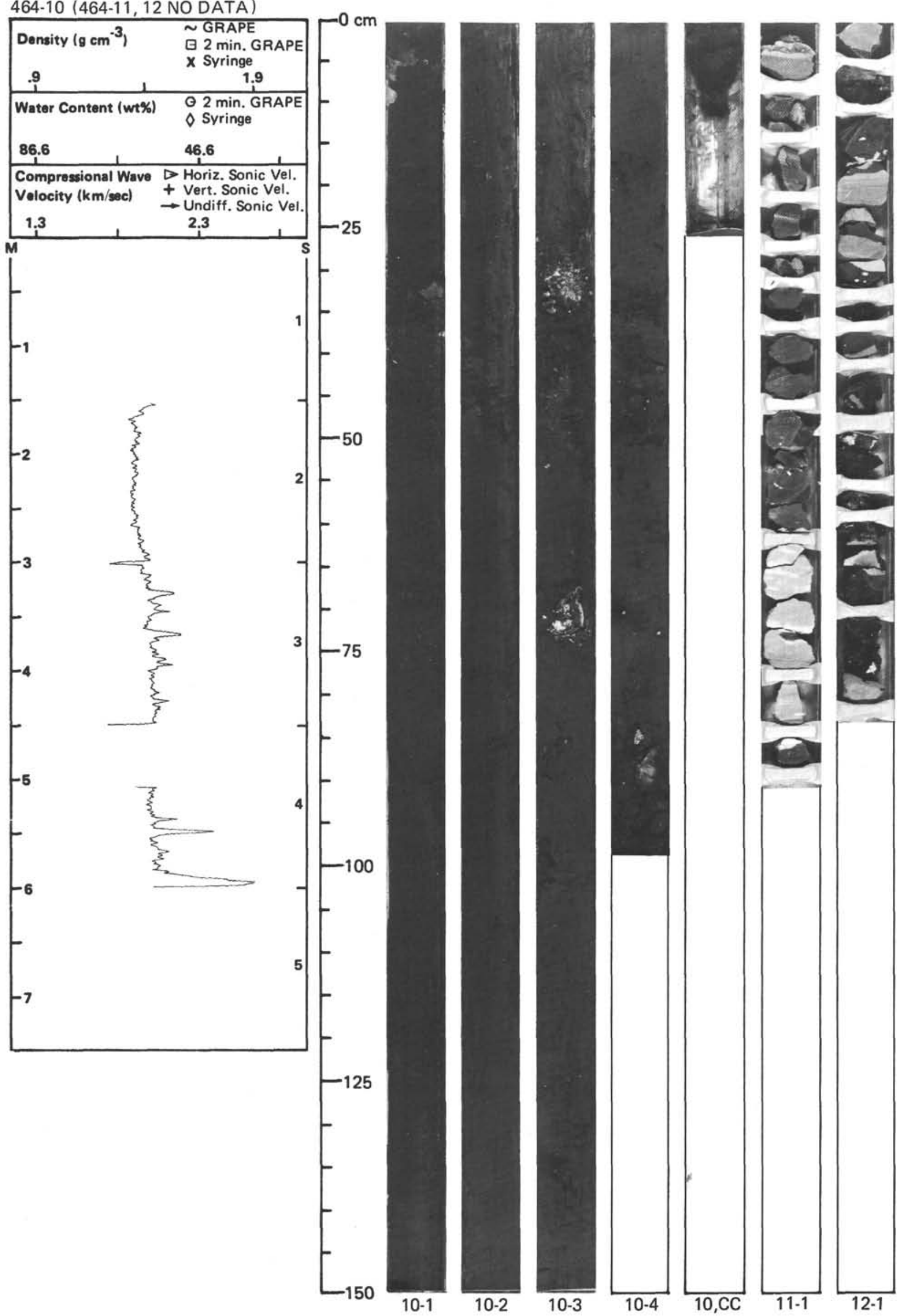




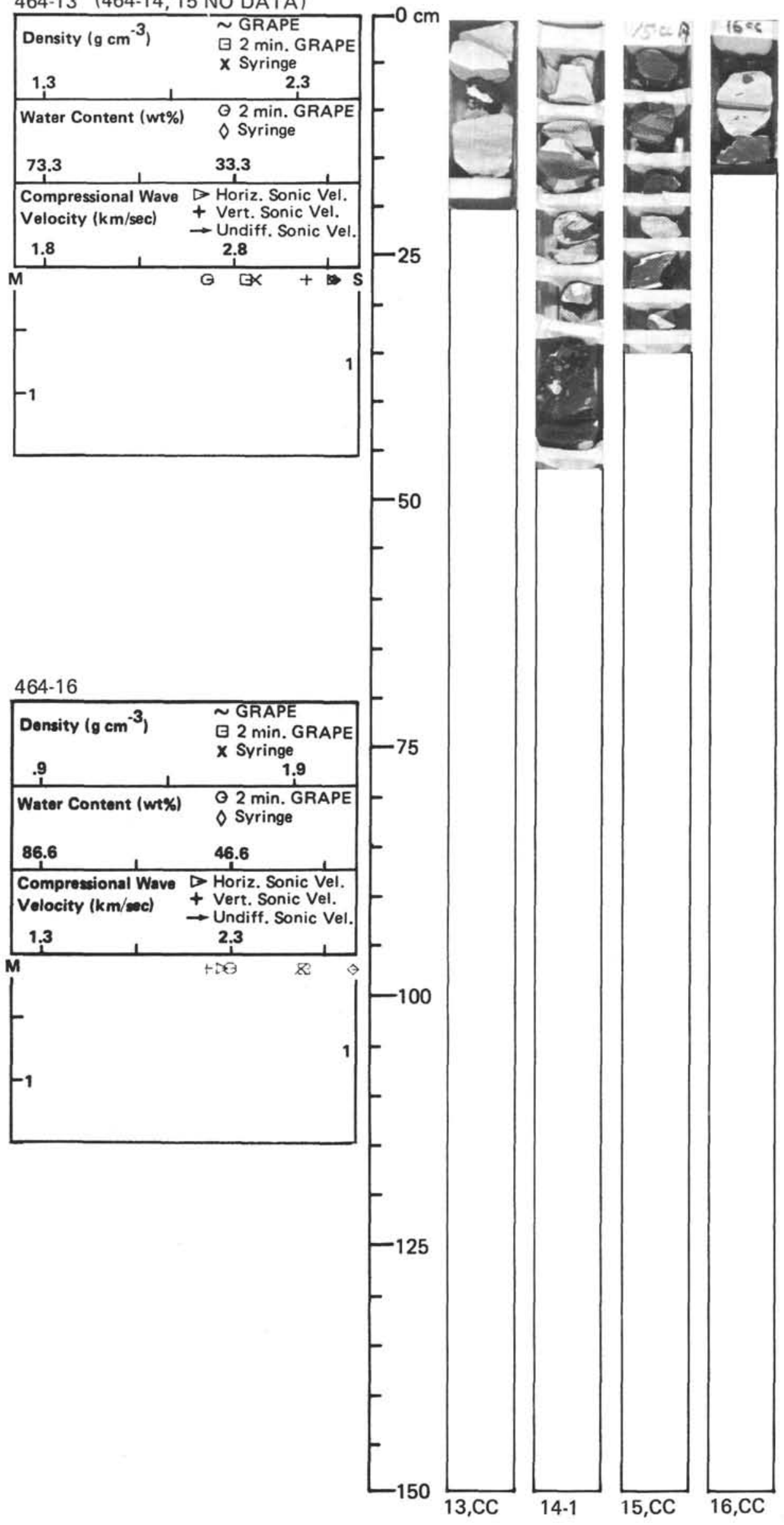




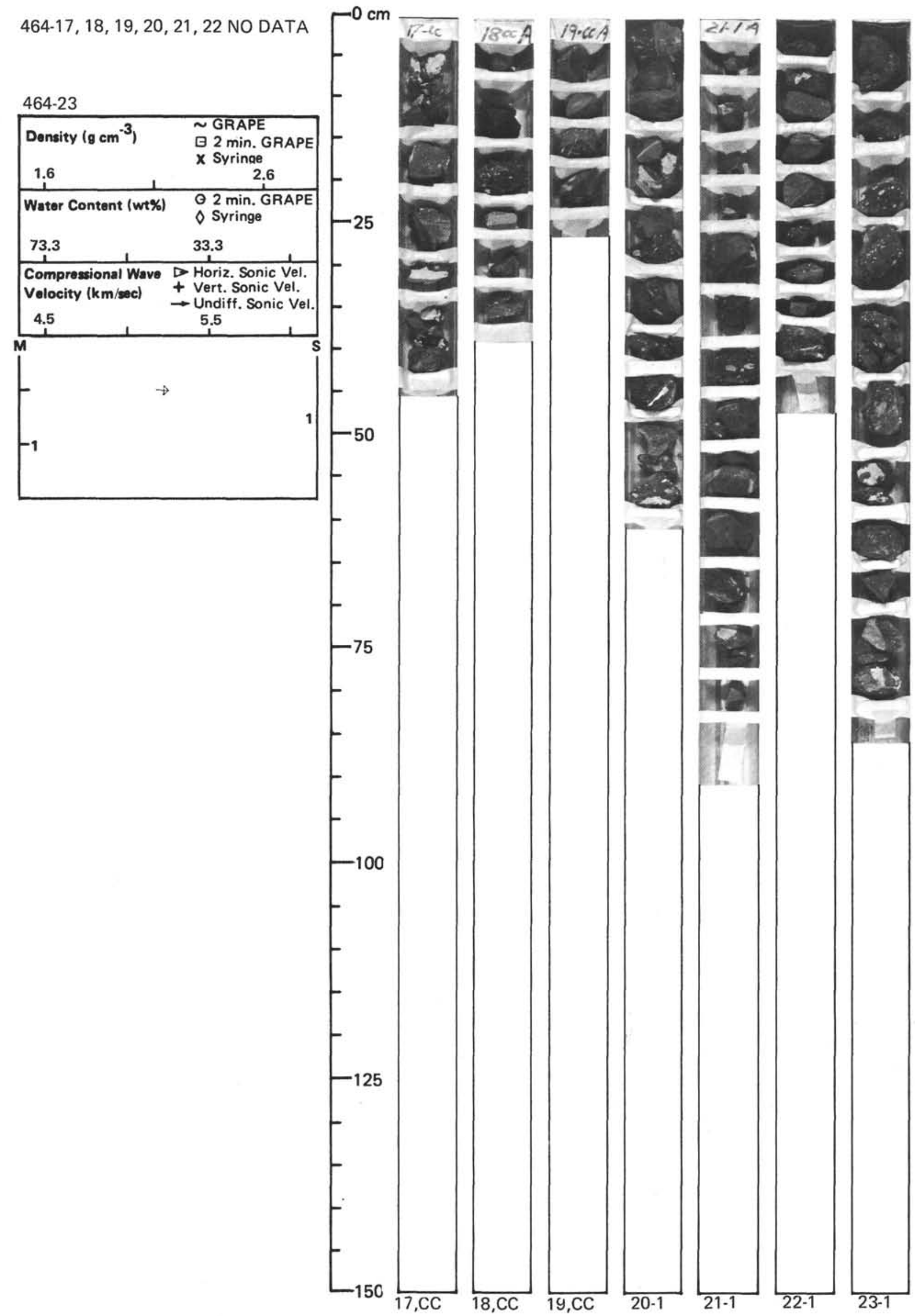




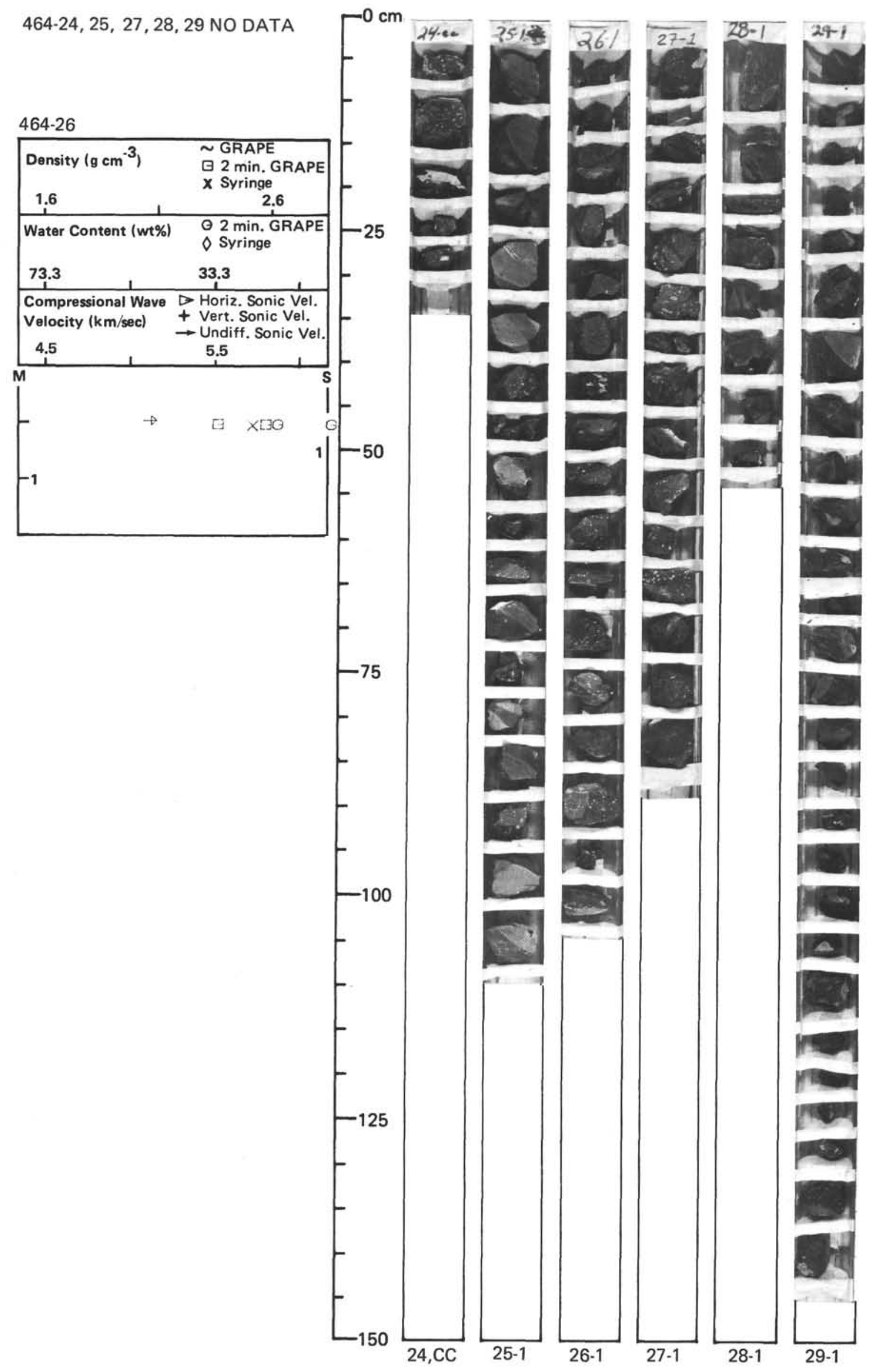




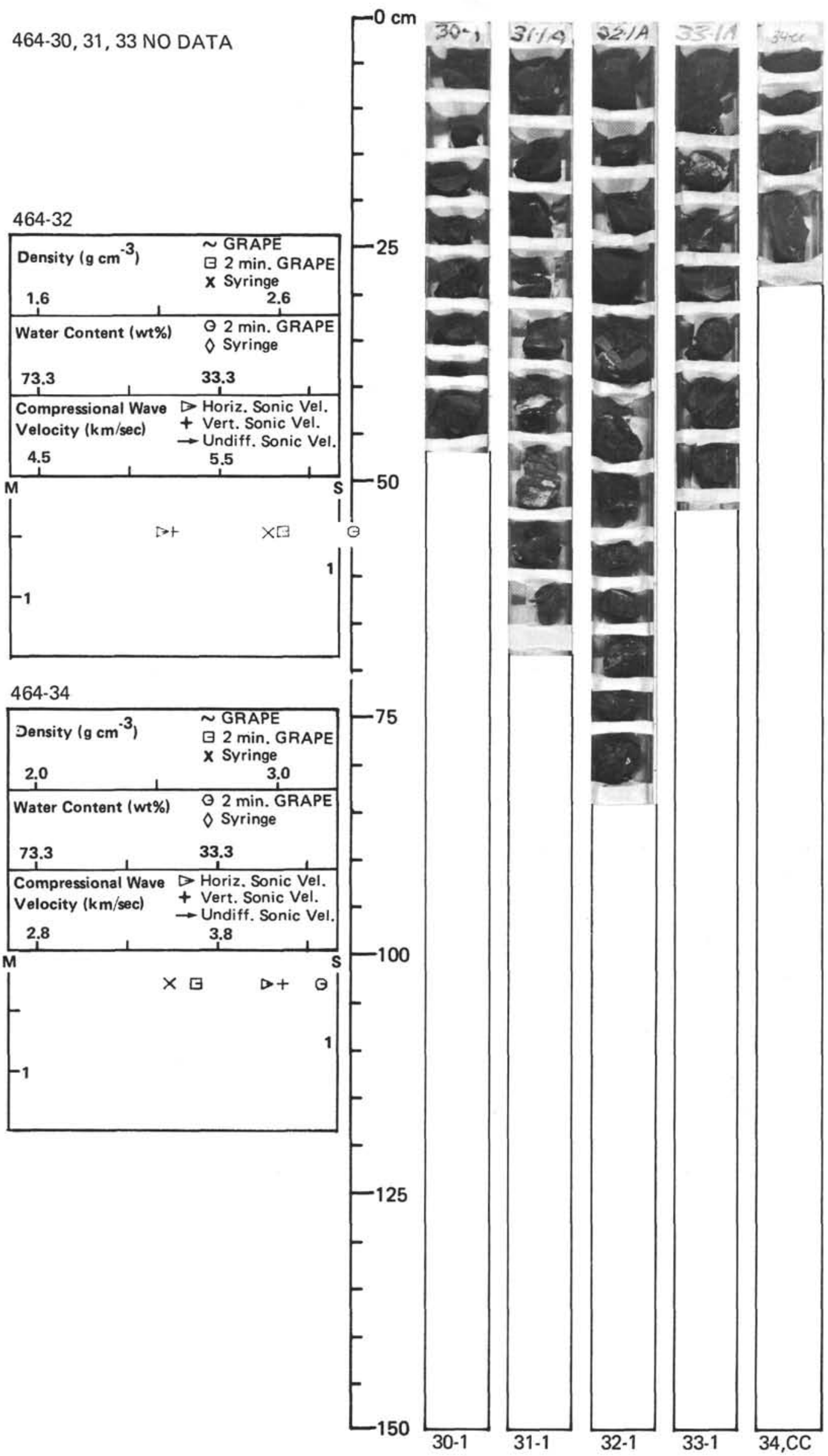

